\title{
SMALL MAMMALS OF THE MAYO RIVER BASIN IN NORTHERN PERU, WITH THE DESCRIPTION OF A \\ NEW SPECIES OF STURNIRA (CHIROPTERA: PHYLLOSTOMIDAE)
}

PAÚl M. VELAZCO AND BRUCE D. PATTERSON

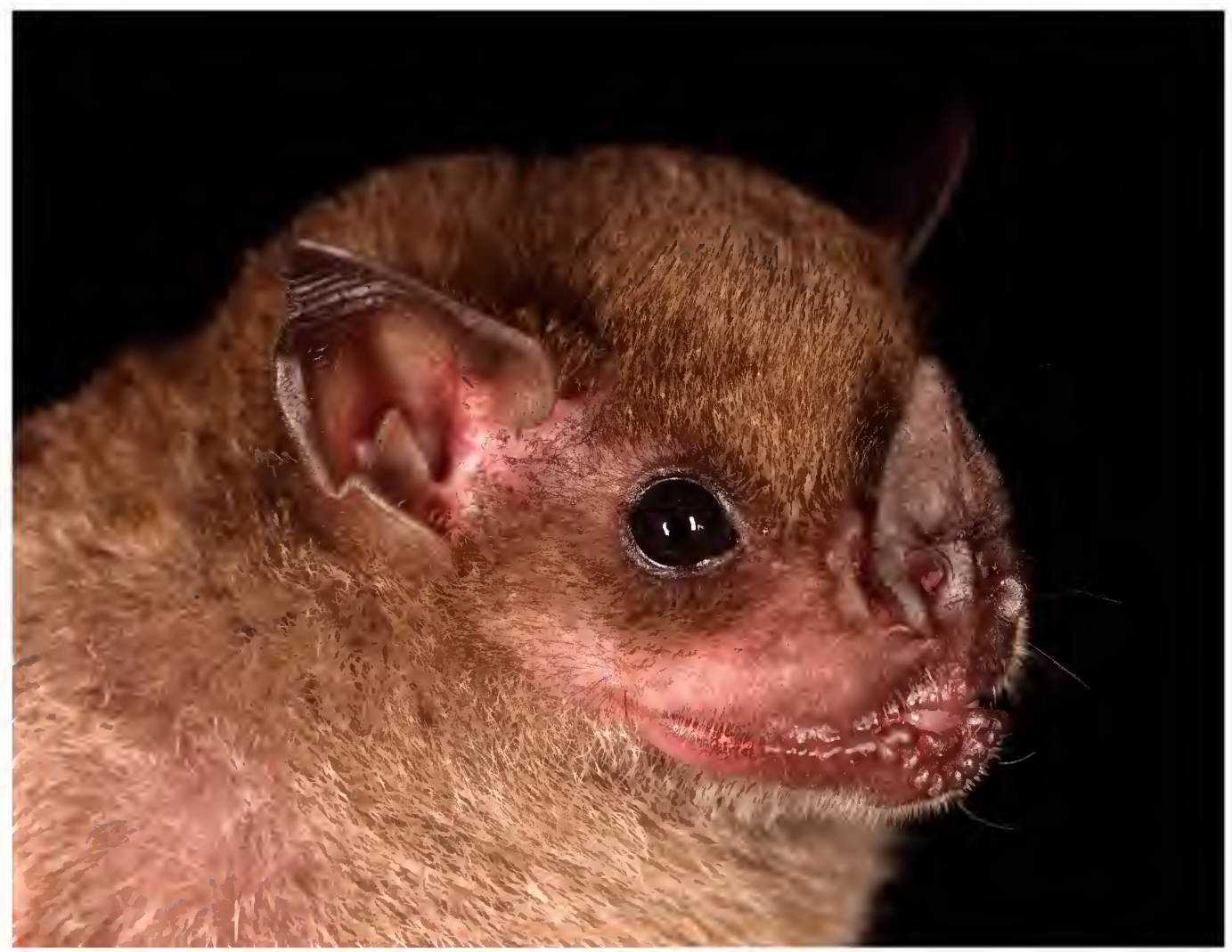

BULLETIN OF THE AMERICAN MUSEUM OF NATURAL HISTORY 


\title{
SMALL MAMMALS OF THE MAYO RIVER BASIN IN NORTHERN PERU, WITH THE DESCRIPTION OF A NEW SPECIES OF STURNIRA (CHIROPTERA: PHYLLOSTOMIDAE)
}

\author{
PAÚL M. VELAZCO \\ Division of Vertebrate Zoology (Mammalogy) \\ American Museum of Natural History
}

BRUCE D. PATTERSON

Integrative Research Center

Field Museum of Natural History

BULLETIN OF THE AMERICAN MUSEUM OF NATURAL HISTORY

Number 429, 67 pp., 7 figures, 25 tables

Issued April 5, 2019 


\section{CONTENTS}

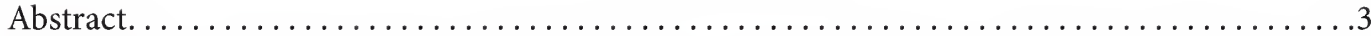

Introduction . . . . . . . . . . . . . . . . . . . . . . . . . . . . . . . . . . .

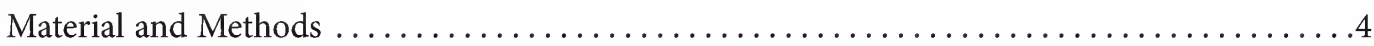

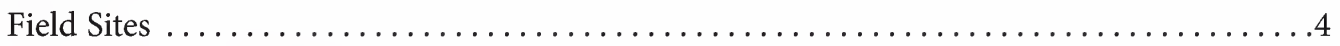

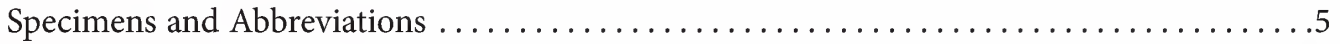

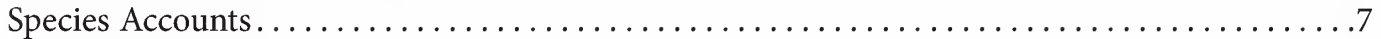

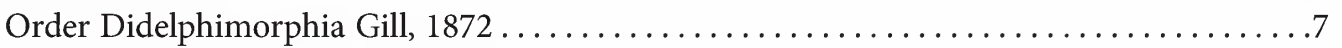

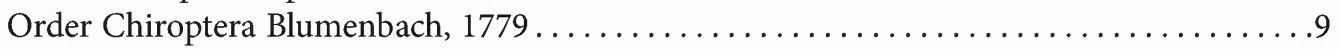

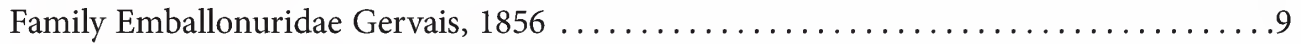

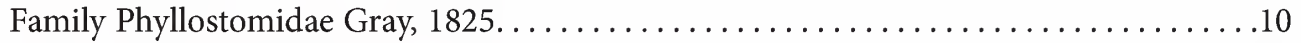

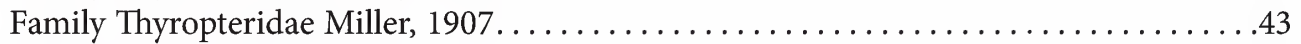

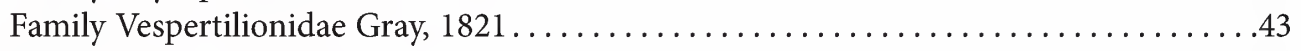

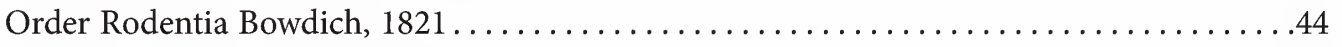

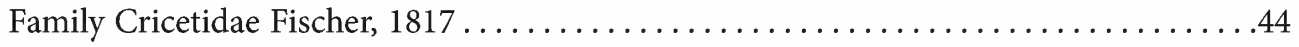

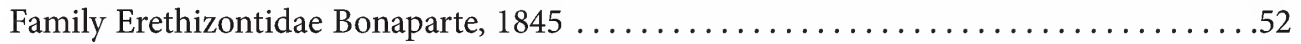

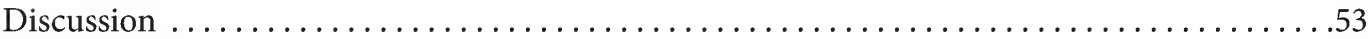

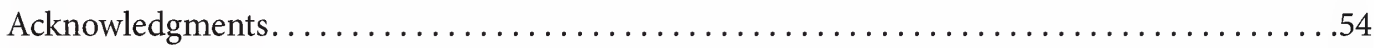

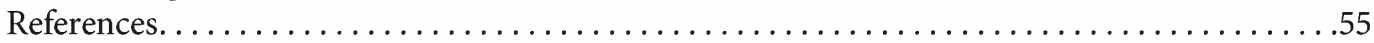

Appendix: Selected Collecting Localities for Sturnira giannae ....................66 


\section{ABSTRACT}

We present the results of an inventory of small mammals in the Mayo River basin, one of the least-studied regions of the Central Andes in Peru. We conducted inventories at three locations in May 2007. We collected 47 species of small mammals in the study area: five marsupials, 31 bats, and 11 rodents. A new species of Sturnira was encountered and is described. The new species, which was previously confused with S. lilium, occurs east of the Andes in Colombia, Ecuador, Peru, Bolivia, Venezuela, the Guianas, and Brazil, with an isolated record on the western slope of the Andes in Peru. Additionally, we report the presence of Anoura geoffroyi in Peru, Carollia sp. sensu Solari and Baker (2006) south of the Marañon River, and extend the elevational range of Neacomys spinosus and Oligoryzomys destructor. Our results highlight the need to conduct additional inventories to increase our understanding of the biodiversity of this rich and increasingly impacted region.

\section{INTRODUCTION}

Peru has the fifth most mammal species of any country in the world, second only to Brazil in the New World (Ramírez-Chaves et al., 2016). This high diversity can be attributed to the juxtaposition in Peru of several Neotropical regions, including Andean slopes, Amazonia, the Altiplano, and the arid Pacific coast. This diverse group of regions supports a rich and heterogeneous mammal fauna, with endemic species occurring in each one of these regions (Pacheco et al., 2009).

The eastern versant of the Central Andes is one of the major centers of endemism in the Andes (Patterson et al., 2012). Several inventories have been conducted in the central and southern regions of the Central Andes (e.g., Emmons et al., 2001; Solari et al., 2006; Pacheco et al., 2013); however, few inventories have focused on the northern Central Andes in Peru (e.g., Leo and Romo R., 1992; Butchart et al., 1995; Leo, 1995).

The Mayo River, a tributary of the Huallaga River, runs from west to east and flows entirely within the department of San Martín, Peru (fig. 1), crossing several habitats including montane cloud forest, premontane cloud forest, and lowland rainforest. The Mayo River basin extends for roughly 10 million $\mathrm{km}^{2}$, with $91 \%$ of that area in the department of San Martín and the remaining 9\% in the department of Amazonas (SENAMHI, 2009). The basin includes highlands $>3,400 \mathrm{~m}$ above sea level as well as lowlands to $200 \mathrm{~m}$, and its natural habi- tats are vital for watershed protection and for carbon sequestration. Two protected areas are present in the Mayo River basin, the Área de conservación regional Cordillera Escalera (ACRCE) and the Bosque de Protección Alto Mayo (BPAM) (fig. 1). Both are part of the Abiseo-Condor-Kutuku Conservation Corridor, established to safeguard a system that supports high numbers of endemic plant and animal species. But despite these protections, the region is under continuing threats: insufficient funds for protected area management, construction of a national highway that crossed the region in 1975, and the resulting high rates of migration and settlement of people from the Andes into lowland areas. As a result, even BPAM has suffered exceptionally high rates of deforestation (Parks Watch, 2003; Gonzales Inca and Llanos López, 2015) and unprotected areas are almost entirely given over to agriculture.

Given its geographic position, the Mayo River region potentially supports a full range of mammalian diversity. Despite the documented presence of endemic species that serve as global flagships, such as the yellow-tailed woolly monkey (Lagothrix flavicauda) and the Río Mayo titi (Callicebus oenanthe), few studies have documented its mammalian diversity (e.g., von Tschudi, 1844; Miller, 1913; Osgood, 1913, 1914; Thomas, 1924, 1927; DeLuycker, 2007). In this article, we present the results of a mammal inventory conducted at the end of the rainy season (May) in four localities in the Mayo River basin. 


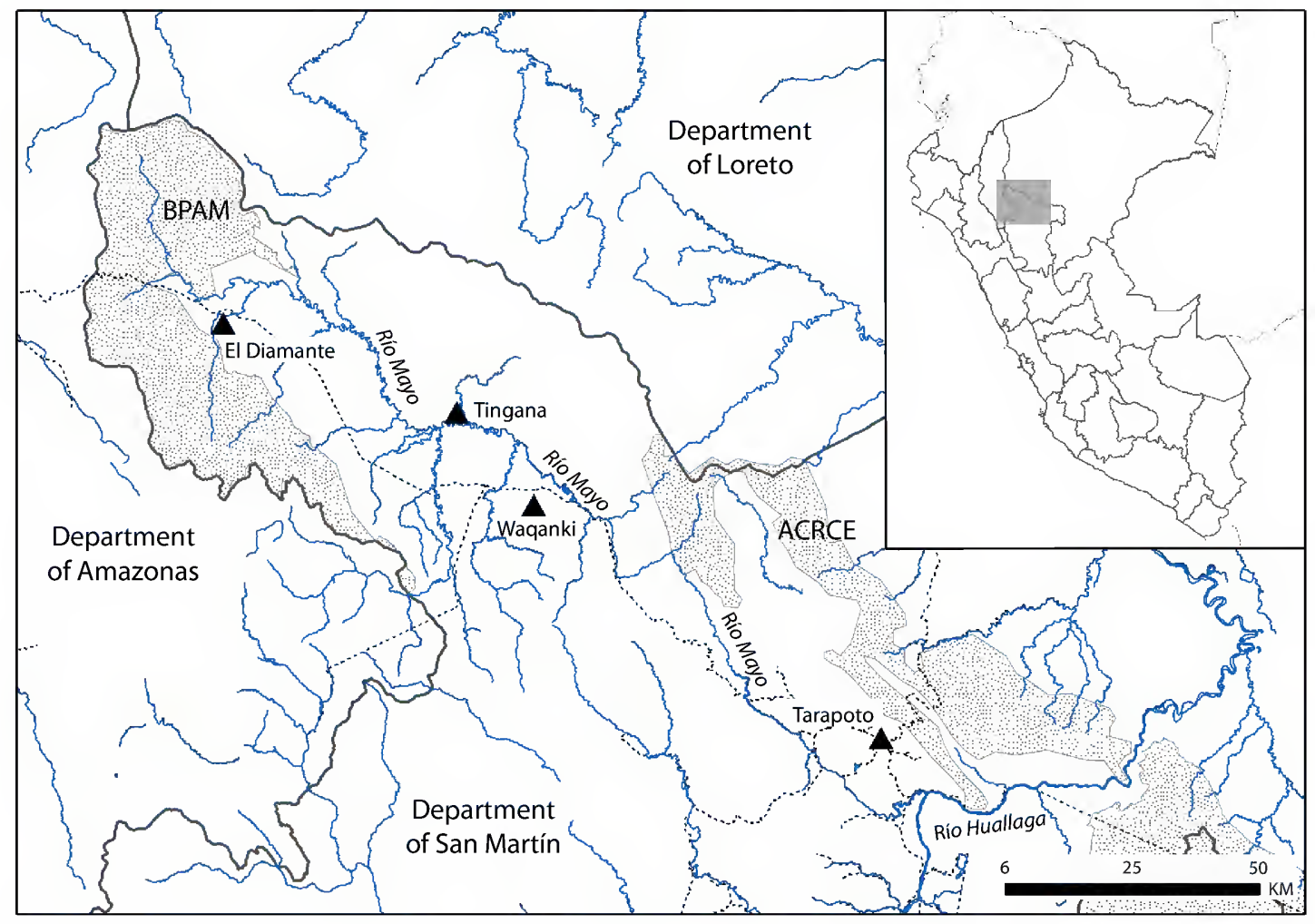

FIG. 1. Map of the Mayo River basin indicating the position of the four sampling localities (see Material and Methods for geographic coordinates and other information). Abbreviations: ACRCE, Área de conservación regional Cordillera Escalera; BPAM, Bosque de Protección Alto Mayo.

\section{MATERIAL AND METHODS}

\section{FIELD Sites}

The collections and observation reported below were obtained from four localities within the Mayo River basin (fig. 1). Fieldwork was carried out 1-25 May, 2007. Below the four localities are listed, as well as their inclusive inventory dates, habitats present, and mist-net and trap effort.

Waqanki (2-10 May 2007): An orchid farm located $3 \mathrm{~km}$ south of Moyobamba, $970 \mathrm{~m}, 06^{\circ}$ $04^{\prime} 30.2^{\prime \prime}$ S, $76^{\circ} 58^{\prime} 33.5^{\prime \prime} \mathrm{W}(6.075100 \mathrm{~S}, 76.976000$ W). The Waqanki center is part of the Área de Conservación Municipal Mishquiyacu-Rumiyacu y Almendra. This site is situated in a disturbed premontane forest drained by a stream, sur- rounding grasslands, and a farm house. Our total sampling effort consisted of 81 net nights and 1458 trap nights.

El Diamante (10-16 May 2007): Rioja, Pardo Miguel, Naranjos, Caserio El Diamante, $1078 \mathrm{~m}$, $05^{\circ} 45^{\prime} 12.1^{\prime \prime} \mathrm{S}, 77^{\circ} 31^{\prime} 34.0^{\prime \prime} \mathrm{W}(5.753400 \mathrm{~S}$, $77.526100 \mathrm{~W})$. This site sampled active coffee plantations. Our total sampling effort consisted of 30 net nights and 375 trap nights.

Tingana (17-24 May 2007): $1 \mathrm{hr} 45 \mathrm{~min}$ by road and boat from Moyobamba, $815 \mathrm{~m}, 05^{\circ} 54^{\prime}$ $38.4^{\prime \prime}$ S, $77^{\circ} 06^{\prime} 43.3^{\prime \prime}$ W (5.910700 S, 77.112000 W). Located on the Río Avisado, Tingana is part of the Área de Conservación Municipal Asociación Hídrica Aguajal Renacal del Alto Mayo. This site was covered primarily by seasonally flooded forest (dominated by Coussapoa trinervia 
and Ficus trigona) and agricultural fields. Our total sampling effort consisted of 56 net nights and 1100 trap nights.

Tarapoto (1 May 2007): City center, $335 \mathrm{~m}$, $06^{\circ} 29^{\prime} 16^{\prime \prime} \mathrm{S}, 76^{\circ} 21^{\prime} 34^{\prime \prime} \mathrm{W}(6.487778 \mathrm{~S}$, $76.359444 \mathrm{~W})$. Tarapoto is the largest city of the department of San Martín. We only had one incidental capture in this locality, a Lonchophylla handleyi that was captured by hand.

A meteorological station near the El Diamante locality registered a stable temperature throughout the year (2007) with an average minimum temperature of $18.3^{\circ} \mathrm{C}$ and a maximum of $28.7^{\circ} \mathrm{C}$. The months with higher precipitation in 2007 were January, March, April, and September through December, when it rained an average of 4.1 to $11.4 \mathrm{~mm}$ monthly. In May the average precipitation was $3.2 \mathrm{~mm}$ (SENAMHI portal).

\section{Specimens And AbBreviations}

Marsupial and Rodent Trapping and Measurements: We used standard trapping equipment (Voss and Emmons, 1996; Voss et al., 2001; Hice and Velazco, 2012) to sample the local fauna of small marsupials and rodents near ground level during our field seasons. Each trap station included three different trap types: one single-spring Victor snap-type rat trap, one Museum Special back-break trap, and one standard (LFA) folding Sherman live trap. In each locality sampled, the number of stations in each line transect varied based on the availability of trails. Trap stations were placed along trails at 10-15 m intervals. A mixture of peanut butter, oatmeal, and vanilla extract was used as bait for all traps. Additionally, a shotgun was used to collect mammals that were observed in trees (Didelphis and Coendou).

Vouchers specimens were prepared as either standard stuffed skins with accompanying skulls and partial skeletons, as skins and skulls with bodies in fluid (fixed in 10\% formalin and transferred to $70 \%$ ethanol), or as fluid specimens; skulls were later removed and cleaned from some of these. The collection totals 357 specimens (marsupial, rodents, and bats) and was divided equally between the Field Museum of Natural History, Chicago, Illinois (FMNH), and the Museo de Historia Natural, Universidad Nacional Mayor de San Marcos, Lima, Peru (MUSM).

External measurements for marsupials and rodents were taken from dead individuals prior to specimen preparation, as follows:

Total length (TTL): Distance from the tip of the snout to the tip of the last caudal vertebra.

Tail length (TL): Measured from the point of dorsal flexure of the tail with the sacrum to the tip of the last caudal vertebra.

Hind-foot length (HF): From proximal margin of calcaneus to tip of the claw of the longest toe.

Ear length (EL): From the notch to the fleshy tip of the pinna.

Cranial measurements were taken with digital calipers to the nearest 0.1 . Different sets of measurements were taken for marsupials and rodents. Our quantitative comparisons of marsupial crania are based on the following measurements:

Condylobasal length (CBL): From the posteriormost point on the occipital condyles to the anteriormost point of the premaxillae.

Nasal breadth (NB): Measured across the junction of the nasal, frontal, and maxillary bones on each side.

Least interorbital breadth (LIB): Measured at the narrowest point across the frontals between the orbits.

Least postorbital breadth (LPB): Measured at the narrowest point across the frontals behind the orbits.

Palatal breadth (PB): Measured across the labial extremes of the crowns of the last molars.

Palatal length (PL): Measured in the midline from the anteriormost point of the premaxillae to the end of the palate.

Zygomatic breadth (ZB): Greatest breadth across the zygomatic arches. 
Maxillary toothrow length (MTR): From the anteriormost edge of the canine to the posteriormost edge of the crown of M4.

Length of molars (LM): From the anteriormost edge of $\mathrm{M} 1$ crown to the posteriormost edge of the crown of M4.

Quantitative comparisons of rodent crania are based on the following measurements:

Condyloincisive length (CIL): From the posteriormost point on the occipital condyles to the anteriormost point on the upper incisors.

Length of diastema (LD): From the crown of the first cheektooth to the lesser curvature of the incisor on the same side.

Maxillary toothrow length (MTR): From the anteriormost edge of $\mathrm{P} 4$ crown to the posteriormost edge of the crown of M3 (except as noted in some tables, where the alveolar equivalent was measured).

Length of molars (LM): From the anteriormost edge of M1 crown to the posteriormost edge of the crown of M3.

Breadth of M1 (BM1): Greatest crown breadth of the first maxillary molar.

Length of incisive foramen (LIF): Greatest anterior-posterior dimension of one incisive foramen.

Breadth of incisive foramina (BIF): Greatest transverse dimension across both incisive foramina.

Breadth of palatal bridge (BPB): Measured between the protocones of the right and left first maxillary molars.

Breadth of zygomatic plate (BZP): Least distance between anterior and posterior edges of the zygomatic plate.

Length of rostrum (LR): From the tip of one nasal bone to the posterior margin of the zygomatic notch on the same side.

Length of nasals (LN): Greatest anterior-posterior dimension of one nasal bone.

Least interorbital breadth (LIB): Least distance across the frontal bones between the orbital fossae.
Braincase breadth (BB): Greatest breadth of the globular part of the braincase above and slightly behind the squamosal zygomatic processes.

Zygomatic breadth (ZB): Greatest breadth across the zygomatic arches.

Zygomatic length (ZL): From the posterior margin of the infraorbital foramen to the posterolateral corner of the zygomatic arch.

Bat Capture and Measurements: We used mist nets of different lengths $(6,9$, and $12 \mathrm{~m})$ set at ground level to capture bats at three localities. The number of mist nets set in each locality varied based on the availability of suitable flyways but averaged approximately eight mist nets per night. Voucher specimens of bats were prepared following the same method described for marsupials and rodents.

External measurements for bats were taken from dead individuals prior to specimen preparation, as follows:

Total length (TTL): Distance from the tip of the snout to the tip of the last caudal vertebra.

Tail length (TL): Measured from the point of dorsal flexure of the tail with the sacrum to the tip of the last caudal vertebra.

Hind-foot length (HF): From the anterior edge of the base of the calcar to the tip of the claw of the longest toe.

Ear length (EL): From the notch to the fleshy tip of the pinna.

Forearm length (FA): From the elbow (tip of the olecranon process) to the wrist (including the carpals). This measurement is made with the wing at least partially folded.

Cranial measurements of bats were taken with digital calipers to the nearest 0.1 . Our quantitative comparisons of bat crania are based on the following measurements:

Greatest length of skull (GLS): From the posteriormost point on the occiput to the anteriormost point on the premaxillae (excluding the incisors). 
Condyloincisive length (CIL): From the posteriormost point on the occipital condyles to the anteriormost point on the upper incisors.

Condylocanine length (CCL): From the posteriormost point on the occipital condyles to the anteriormost point on the upper canines.

Lacrimal breadth (LB): Greatest breadth across the lacrimal (= anteorbital) ridges, when present and well defined.

Postorbital breadth (POB): Least breadth across the frontals posterior to the postorbital processes or bulges.

Zygomatic breadth (ZB): Greatest breadth across the zygomatic arches.

Braincase breadth (BCB): Greatest breadth of the globular part of the braincase.

Mastoid breadth (MB): Greatest cranial breadth across the mastoid region.

Maxillary toothrow length (MTR): From the anteriormost edge of the canine crown to the posteriormost edge of the crown of M3.

Breadth across molars (BM): Greatest breadth across the outer edges of the crowns of the upper molars.

Breadth across canines (BC): Greatest breadth across the outer edges of the crowns of the upper canines.

Dentary length (DENL): Distance from midpoint of condyle to the anteriormost point of dentary.

Mandibular toothrow length (MANDL): Distance from anteriormost surface of the lower canine to the posteriormost surface of $\mathrm{m} 3$.

We follow Dávalos et al. (2014; MorphoBank project 891, http://dx.doi.org/10.7934/P891) in assigning homology for bat premolars. When three upper premolars are present (e.g., Anoura), the first upper premolar corresponds to $\mathrm{P} 1$, the second to P4, and the third one to P5. If only two are present (e.g., Lophostoma) these correspond to P4 and P5 and if only one is present (e.g., Desmodus) it corresponds to P5. The lower premolar homologies are not as straightforward as those of the upper premolars. When three lower premolars are present (e.g., Glossophaga, Thyroptera) these correspond to $\mathrm{p} 1, \mathrm{p} 4$ and $\mathrm{p} 5$, but if only two are present in some cases they apparently correspond to p1 and p5 (e.g., Artibeus, Sturnira, Uroderma) whereas in other cases they correspond to p4 and p5 (e.g., Carollia, Desmodus).

Additional comparative voucher material used in the description of the new species of Sturnira is housed in the following museums: American Museum of Natural History, New York (AMNH); the Natural History Museum, London (formerly the British Museum of Natural History, London; BMNH); Carnegie Museum of Natural History, Pittsburgh, (CM); Field Museum of Natural History, Chicago (FMNH); Museo de Historia Natural, Universidad Nacional Mayor de San Marcos, Lima (MUSM); Royal Ontario Museum, Toronto, Ontario (ROM); Museum of Texas Tech University, Lubbock, Texas (TTU), and the Bavarian State Collection of Zoology, Munich (ZSM).

\section{SPECIES ACCOUNTS}

\section{Order Didelphimorphia Gill, 1872}

Family Didelphidae Gray, 1821

The higher-level taxonomy of this family has changed dramatically from earlier treatments (e.g., Gardner, 2008a) due to the work of Voss and Jansa (2009). Based on strongly supported molecular and morphological analyses, they recognized four subfamilies in Didelphidae: Caluromyinae (for Caluromys and Caluromysiops), Glironiinae (Glironia), Hyladelphinae (Hyladelphys), and Didelphinae. Additionally, they recognized four tribes in Didelphinae: Didelphini (for Chironectes, Didelphis, Lutreolina, and Philander), Marmosini (Marmosa, Monodelphis, and Tlacuatzin), Metachirini (Metachirus), and Thylamyini (Chacodelphys, Cryptonanus, Gracilinanus, Lestodelphys, Marmosops, and Thylamys). Another taxonomic change suggested by Voss 
and Jansa (2009) is the recognition of the genus Micoureus as a subgenus of Marmosa.

\section{Subfamily Didelphinae Gray, 1821}

Members of this subfamily are characterized by their lack of an anterior cutting edge on the third upper premolar (Voss and Jansa, 2009). All five species of didelphids recorded at the three sampled localities belong to this subfamily.

\section{Tribe Didelphini Gray, 1821}

\section{Didelphis marsupialis Linnaeus, 1758}

Voucher Material: Waqanki: 1 adult male (FMNH 203508); Tingana: 1 adult female (MUSM 39246); see table 1 for measurements.

IDENTIFICATION: We consulted descriptions and measurements of Didelphis marsupialis provided by Gardner (1973), Patton et al. (2000), Voss et al. (2001), Lemos and Cerqueira (2002), Cerqueira and Tribe (2008), and Hice and Velazco (2012). Our Mayo River basin specimens exhibit all the diagnostic characteristics of this species (e.g., ears entirely black, lack of facial markings, jugal embracing the squamosal zygomatic process both above and below) and fall within the range of measurements previously reported for Didelphis marsupialis (table 1).

Remarks: Our two individuals were shot, MUSM 39246 at 06:00 hours in an agricultural field and FMNH 203508 at 22:00 hours in a tree overhanging a chicken coop.

Tribe Marmosini Hershkovitz, 1992

Marmosa (Micoureus) regina Thomas, 1898

Voucher Material: Waqanki: 1 adult male (FMNH 203510); see table 1 for measurements.

IDENTIFICATION: The systematics and taxonomy of this subgenus is still confused and future taxonomic changes will probably be necessary due to the high molecular diversity in this group (e.g., de la Sancha et al., 2011). We consulted the descriptions and measurements of Marmosa (Micoureus) regina provided by Hice and Velazco (2012), Patton et al. (2000), and Voss and Jansa (2009). Our single specimen conforms in all respects to the morphology previously described for Marmosa regina (e.g., dense but short fur, base of the tail covered with fur $[<20 \mathrm{~mm}]$, palatine fenestrae absent).

REMARKs: Our single specimen was caught in a Victor rat trap in a forest.

Tribe Thylamyini Hershkovitz, 1992

$$
\text { Marmosops (Marmosops) caucae }
$$

(Thomas, 1900)

Voucher Material: Tingana: 1 adult female (FMNH 203324), 2 juvenile males (FMNH 203326; MUSM 39248); see table 2 for measurements.

IDENTIFiCATion: We follow Díaz-Nieto et al. (2011) and Díaz-Nieto et al. (2016) in recognizing M. caucae as a species distinct from M. impavidus. Our specimens conform in all respects to the morphology and measurements described by Díaz-Nieto et al. (2011) for M. caucae (e.g., interdigital pad 4 and hypothenar pad of hind foot in contact, two antebrachial vibrissae, palatine fenestrae present, subsquamosal foramen constricted anteroposteriorly, absence of accessory cusps on the upper canine).

Remarks: The adult female was caught in a Victor rat trap in an agricultural field. The two adult males were caught in Victor rat traps in a renacal (flooded forest of Coussapoa trinervia).

\section{Marmosops (Marmosops) noctivagus}

(Tschudi, 1845)

Voucher Material: El Diamante: 1 adult male (MUSM 39249); see table 2 for measurements.

IDENTIFICATION: We consulted the descriptions and measurements of Marmosops noctiva- 
TABLE 1

External and craniodental measurements $(\mathrm{mm})$ and weights $(\mathrm{g})$ of Didelphis marsupialis and Marmosa regina

\begin{tabular}{lcccc}
\hline \hline & \multicolumn{2}{c}{ Didelphis marsupialis } & & Marmosa regina \\
\cline { 2 - 3 } W & FMNH 203508 & MUSM 39246 & FMNH 203510 o \\
TTL & 1840 & 1270 & 107.5 \\
TL & 840 & 814 & 418 \\
HF & 431 & 415 & 238 \\
EL & 61 & 57 & 27 \\
CBL & 54 & 49 & 26 \\
NB & 105.5 & - & 42.1 \\
LIB & 16.1 & 13.3 & 6.3 \\
LPB & 20.7 & 19.5 & 8.2 \\
PB & 12.6 & - & 7.8 \\
PL & 32.2 & 28.6 & 14.0 \\
ZB & 64.6 & - & 23.0 \\
MTR & 56.5 & - & 24.3 \\
LM & 42.6 & 42.8 & 17.4 \\
\hline
\end{tabular}

gus provided by Hice and Velazco (2012), Gardner and Creighton (2008), Patton et al. (2000), Díaz-Nieto (2012), and Díaz-Nieto et al. (2016). Our specimen conforms in all respects to previous descriptions of Marmosops noctivagus: dorsal pelage dark brown to reddish brown, broad ventral band of white self-colored hairs, presence of lateral carpal tubercles, absence of medial carpal tubercles, supraorbital region distinctly beaded with elevated lateral ridges extending posteriorly onto parietals (lateral ridges are parallel), maxillary fenestra absent, and upper canines without accessory cusps.

Remarks: Caught in a Victor rat trap in an ecotone between farmland and secondary forest.

\section{Marmosops (Sciophanes) bishopi (Pine, 1981)}

Voucher Material: El Diamante: 2 adult males (FMNH 203328; MUSM 39247); see table 2 for measurements.

IDENTIFICATION: We consulted the descriptions and measurements of Marmosops bishopi provided by Hice and Velazco (2012), Gardner and Creighton (2008), Voss et al. (2001), DíazNieto (2012), Díaz-Nieto et al. (2016), and DíazNieto and Voss (2016). Our specimens conform in all respects to previous descriptions of Marmosops bishopi. They have a continuous band of self-colored ventral white hairs, bladelike lateral carpal tubercles, single posterior accessory cusps on the upper canines (anterior accessory cusp absent), and absence of palatal vacuities, all of which are diagnostic characteristics for this species according to Díaz-Nieto and Voss (2016).

REMARKS: Both specimens were caught in Victor rat traps in an ecotone between banana/ coffee plantations and secondary forest.

\section{Order Chiroptera Blumenbach, 1779}

Family Emballonuridae Gervais, 1856

This pantropical family currently comprises 14 extant genera and 54 species, 22 of which are Neotropical. Emballonurids are characterized by long, soft fur, lack of facial ornamentation, unusu- 
TABLE 2

External and craniodental measurements $(\mathrm{mm})$ and weights $(\mathrm{g})$ of Marmosops bishopi, M. neblina, and M. noctivagus

\begin{tabular}{|c|c|c|c|c|c|c|}
\hline & \multicolumn{2}{|c|}{ Marmosops bishopi } & \multicolumn{3}{|c|}{ M. caucae } & \multirow{2}{*}{$\frac{\text { M. noctivagus }}{\text { MUSM } 39249}$} \\
\hline & $\begin{array}{c}\text { FMNH } 203328 \\
\delta\end{array}$ & $\begin{array}{c}\text { MUSM } \\
\text { ơ }\end{array}$ & $\begin{array}{c}\text { FMNH } 203324 \\
q\end{array}$ & $\begin{array}{c}\text { FMNH } 203326 \\
\delta\end{array}$ & $\begin{array}{c}\text { MUSM } 39248 \\
\delta\end{array}$ & \\
\hline W & 23 & 28 & 31 & 14 & 14 & 25 \\
\hline TTL & 247 & 254 & 253 & 194 & 197 & 241 \\
\hline $\mathrm{TL}$ & 136 & 143 & 148 & 112 & 109 & 139 \\
\hline $\mathrm{HF}$ & 17 & 17 & 18 & 15 & 14 & 15 \\
\hline EL & 16 & 20 & 18 & 19 & 18 & 18 \\
\hline CBL & 28.6 & 29.1 & 30.5 & 24.7 & 24.8 & 29.6 \\
\hline NB & 3.4 & 3.5 & 3.7 & 3.4 & 3.4 & 3.6 \\
\hline LIB & 5.7 & 5.9 & 5.6 & 5.3 & 5.3 & 5.9 \\
\hline LPB & 6.1 & 5.9 & 6.0 & 5.9 & 6.0 & 7.0 \\
\hline $\mathrm{PB}$ & 8.5 & 8.8 & 9.7 & 7.9 & 8.1 & 11.5 \\
\hline PL & 16.0 & 16.3 & 17.5 & 14.0 & 14.2 & 17.1 \\
\hline $\mathrm{ZB}$ & 14.5 & 15.1 & 16.0 & 13.3 & 13.6 & 16.2 \\
\hline MTR & 11.8 & 11.7 & 12.4 & 9.2 & 10.2 & 12.5 \\
\hline LM & 6.4 & 5.8 & 6.3 & 5.2 & 4.8 & 5.9 \\
\hline
\end{tabular}

ally long, thin postorbital processes, and presence of a broad uropatagium from which the tip of the tail emerges dorsally roughly halfway along the length of the membrane (Emmons and Feer, 1997; Simmons and Voss, 1998; Hood and Gardner, 2008; Reid, 2009). Most Neotropical species have glandular wing sacs or pouches located in the propatagium near the elbow (Emmons and Feer, 1997; Reid, 2009). In this study, a single species was recorded at one locality.

\section{Peropteryx kappleri Peters, 1867}

Voucher Material: El Diamante: 3 adult males (FMNH 203512; MUSM 39109, 39110); see table 3 for measurements.

Identification: We consulted the descriptions and measurements of Peropteryx kappleri provided by Sanborn (1937), Goodwin and Greenhall (1961), Husson (1962, 1978), Jones and Hood (1993), Simmons and Voss (1998), and Lim et al. (2010). Two subspecies are currently recog- nized: P. k. kappleri (Central America to Ecuador, Venezuela, Guianas, and southeastern Brazil) and P. k. intermedius (southern Peru) (Hood and Gardner, 2008). Our specimens conform in all respects to previous descriptions of the nominate subspecies: brown wings, ears not connected by a band of skin, lateral pterygoid pits small and shallow, and posterior border of the mesopterygoid extension level with the anterior border of the basisphenoid and lateral pterygoid pits, and a posterior cusp present on the anterior upper premolar. Our Mayo River basin voucher material is also encompassed by the range of measurements reported for the nominate subspecies.

\section{Family Phyllostomidae Gray, 1825}

The Neotropical family Phyllostomidae is the most ecologically diverse family within Mammalia, containing species variously specialized for insectivory, carnivory, omnivory, nectarivory, palynivory, frugivory, and even sanguivory. Phyl- 
TABLE 3

External and craniodental measurements $(\mathrm{mm})$ and weights $(\mathrm{g})$ of Peropteryx kappleri (3 males)

\begin{tabular}{lc}
\hline \hline W & $7.7(7.0-8.2) 3$ \\
TTL & $74.7(67.0-81.0) 3$ \\
TL & $13.8(13.0-15.0) 3$ \\
HF & $10.3(9.0-11.0) 3$ \\
EL & $17.3(16.0-19.0) 3$ \\
FA & $50.7(50.0-51.1) 3$ \\
GLS & $16.7(16.4-17.0) 3$ \\
CIL & $16.1(16.0-16.2) 3$ \\
CCL & $15.6(15.5-15.7) 3$ \\
LB & $6.0(5.8-6.3) 3$ \\
POB & $3.1(3.0-3.2) 3$ \\
ZB & $10.3(9.9-10.7) 3$ \\
BCB & $7.7(7.6-7.8) 3$ \\
MB & $8.6(8.5-8.6) 3$ \\
MTR & $7.0(6.9-7.1) 3$ \\
BM & $7.9(7.7-8.0) 3$ \\
BC & $4.5(4.4-4.6) 3$ \\
\hline
\end{tabular}

lostomids are characterized by having a noseleaf or other narial structures, a humerus with a welldeveloped trochiter, a digit II with a well-developed metacarpal and a small phalanx, a digit III with three completely ossified phalanges, a friction lock on the digits of the feet, a fibula that is proximally cartilaginous, a well-developed tragus, and oviductal folds limited to the extramural oviduct (Simmons and Voss, 1998; Gardner, 2008b).

\section{Subfamily Carolliinae Miller, 1924}

Seven species are currently recognized in this monogeneric subfamily, but perhaps two undescribed species have been identified (Solari and Baker, 2006; Velazco, 2013). Velazco (2013) noted that $C$. brevicauda and $C$. perspicillata exhibit the lowest pairwise cytochrome $b$ divergence among all the species pairs of the genus, suggesting the possibility that brevicauda and perspicillata should be synonymized. However, making a nomenclatural decision affecting two of the most studied mammal species in the Neotropics requires analyses of additional markers.
We recorded four species, one of them unnamed, at the three sampled localities.

Carollia benkeithi Solari and Baker, 2006

Voucher Material: El Diamante: 2 adult males (FMNH 203352; MUSM 39140), 2 adult females (MUSM 39141, 39142); Waqanki: 1 adult female (FMNH 203546), 7 adult males (MUSM 39136-39138; FMNH 203348, 203350, 203544); see table 4 for measurements.

IDENTIFICATION: Descriptions and measurements of Carollia benkeithi were provided by Solari and Baker (2006) and McLellan and Koopman (2008). No subspecies are currently recognized in C. benkeithi (McLellan and Koopman, 2008). Our specimens conform in all respects to previous descriptions of $C$. benkeithi: lateral rim of basisphenoid pits discontinues 3-4 mm anterior to posterolateral margin of basisphenoid, well-developed anterior cingulum of the second upper premolar, second upper premolar oriented in line with the axis of the skull creating an obtuse angle between the margins of the second premolar and 
TABLE 4

External and craniodental measurements ( $\mathrm{mm})$ and weights $(\mathrm{g})$ of Carollia benkeithi and C. brevicauda

\begin{tabular}{lccccc}
\hline \hline & \multicolumn{2}{c}{ Carollia benkeithi } & & \multicolumn{2}{c}{ Carollia brevicauda } \\
\cline { 2 - 3 } \cline { 5 - 6 } W & 9 males & 3 females & & 7 males & 17 females \\
TTL & $10.7(10.0-12.0) 9$ & $11.5(11.0-12.0) 3$ & & $15.6(13.5-18.0) 7$ & $14.3(10.8-16.5) 17$ \\
TL & $64.8(60.0-67.0) 9$ & $63.7(62.0-65.0) 3$ & & $69.3(61.0-76.0) 7$ & $68.0(62.0-75.0) 17$ \\
HF & $9.6(7.0-12.0) 9$ & $10.2(9.5-11.0) 3$ & & $7.7(6.0-9.0) 7$ & $9.2(7.0-13.0) 17$ \\
EL & $10.9(9.0-13.0) 9$ & $10.3(10.0-11.0) 3$ & & $12.7(12.0-15.0) 7$ & $12.5(10.0-15.0) 17$ \\
FA & $16.0(14.0-18.0) 9$ & $17.3(17.0-18.0) 3$ & & $19.3(16.0-21.0) 7$ & $19.4(17.0-21.0) 17$ \\
GLS & $36.0(32.0-38.0) 9$ & $36.7(36.0-37.0) 3$ & & $40.6(38.0-42.0) 7$ & $40.8(39.0-43.0) 17$ \\
CIL & $9.0(18.3-19.6) 6$ & $18.7(18.2-19.0) 3$ & & $21.7(21.3-22.0) 6$ & $21.2(20.2-22.1) 16$ \\
CCL & $17.7(17.3-18.4) 6$ & $17.4(16.9-17.7) 3$ & & $20.3(19.7-20.5) 6$ & $20.0(19.3-20.7) 15$ \\
LB & $17.2(16.6-18.0) 6$ & $16.7(16.4-17.0) 3$ & & $19.6(19.0-19.8) 6$ & $19.3(18.6-20.0) 16$ \\
POB & $5.3(5.0-5.7) 6$ & $5.3(5.2-5.3) 3$ & & $6.2(6.0-6.5) 6$ & $5.9(5.6-6.2) 16$ \\
BCB & $5.2(5.0-5.6) 6$ & $5.4(5.2-5.6) 3$ & & $5.5(5.4-5.8) 6$ & $5.5(5.2-5.8) 16$ \\
MB & $8.7(8.5-8.9) 6$ & $8.7(8.5-8.9) 3$ & & $9.6(9.5-9.8) 6$ & $9.5(9.2-9.8) 16$ \\
MTR & $9.9(9.6-10.2) 6$ & $9.8(9.7-10.0) 3$ & & $11.2(11.0-11.4) 6$ & $10.9(10.4-11.4) 16$ \\
BM & $6.2(5.9-6.5) 6$ & $6.1(5.9-6.2) 3$ & $6.9(6.8-7.1) 6$ & $6.9(6.5-7.5) 15$ \\
BC 6 & $6.9(6.5-7.5) 6$ & $6.9(6.7-7.1) 3$ & & $8.0(7.8-8.2) 6$ & $7.8(7.4-8.2) 16$
\end{tabular}

first molar, and second upper premolar usually not in contact with first upper molar (McLellan and Koopman, 2008). Our Mayo River basin voucher material falls within the range of measurements reported for the species (Solari and Baker, 2006). Velazco (2013) identified the Mayo River basin voucher material as C. benkeithi.

Remarks: The two females (MUSM 3914139142) collected at El Diamante were lactating.

\section{Carollia brevicauda (Schinz, 1821)}

Voucher Material: El Diamante: 9 adult females (FMNH 203356, 203358, 203554, 203556, 203558; MUSM 39145, 39148, 39149, 39151), 4 males (FMNH 203360; MUSM 39146, 39147, 39150); Tingana: 4 adult females (FMNH 203362, 203364; MUSM 39153, 39154), 1 adult male (MUSM 39152); Waqanki: 4 adult females (FMNH 203354, 203548, 203552; MUSM 39143), 2 adult males (FMNH 203550; MUSM 39144); see table 4 for measurements.
IDENTIFICATION: We consulted the descriptions and measurements of Pine (1972), Brosset and Charles-Dominique (1990), and McLellan and Koopman (2008). No subspecies are currently recognized in Carollia brevicauda (McLellan and Koopman, 2008; Velazco, 2013). Our specimens conform in all respects to previous descriptions of C. brevicauda: forearm length ranging from $36 \mathrm{~mm}$ to $41 \mathrm{~mm}$; fur long, thick, and fluffy; forearm, tibia, and toes hairy; outer lower incisors not obscured by cingula of canines when lower jaw viewed in dorsal view; labial outline of upper toothrow evenly curved, without a distinct notch; crown of first lower incisor triangular in outline; and trigonid of $\mathrm{ml}$ distinctly narrower than talonid (Pine, 1972; McLellan and Koopman, 2008). Velazco (2013) identified the Mayo River basin voucher material as $C$. brevicauda.

REMARKs: The wing tips of one male (MUSM 39146) and entire pinnae of one female (FMNH 203358) specimen were white. Twenty-one indi- 
viduals were captured and released, 9 in the Waqanki and 12 in El Diamante localities. Of the released individuals, two females were pregnant (El Diamante) and two others were lactating (one from each locality).

\section{Carollia perspicillata (Linnaeus, 1758)}

Voucher Material: El Diamante: 8 adult females (FMNH 203374, 203380, 203570; MUSM 39162, 39164, 39165, 39166, 39169), 6 adult males (FMNH 203376, 203378, 203572; MUSM 39163, 39167, 39168); Tingana: 12 adult females (FMNH 203382, 203384, 203386, 203388, 203390, 203392, 203396; MUSM 39170, $39171,39174,39177,39178), 7$ adult males (FMNH 203394, 203574, 203576; MUSM 39172, 39173, 39175, 39176); Waqanki: 9 adult females (FMNH 203368, 203370, 203372, 203560, 203566; MUSM 39155, 39156, 39157, 39160), 7 adult males (FMNH 203366, 203562, 203564, 203568; MUSM 39158, 39159, 39161); see table 5 for measurements.

IDENTIFICATION: Descriptions and measurements of Carollia perspicillata were provided by Pine (1972), Goodwin and Greenhall (1961), Husson $(1962,1978)$, Brosset and Charles-Dominique (1990), Cloutier and Thomas (1992), and McLellan and Koopman (2008). We follow Velazco (2013) in not recognizing subspecies in C. perspicillata. Our Mayo River basin specimens exhibit all the diagnostic characteristics of the species (e.g., forearm longer than $39 \mathrm{~mm}$; fur relatively short, sparse, and coarse; forearm and toes naked or only sparsely haired; half or more of the outer lower incisors obscured by cingula of canines, when lower jaw viewed from directly above; $\mathrm{V}$-shaped lower jaw, with straight rami; maxillary toothrow length more than $7.4 \mathrm{~mm}$ ) and its measurements fall within the ranges reported for C. perspicillata. Velazco (2013) identified the Mayo River basin voucher material as C. perspicillata.

REMARKs: Four females collected by us were lactating (FMNH 203377, 203388, 203390;
MUSM 39177). Sixty individuals were captured and released, 36 from the El Diamante, four from the Tingana, and 20 from the Waqanki localities. Of the released individuals, one female was pregnant (El Diamante) and two others were lactating (one from each, El Diamante and Waqanki localities).

\section{Carollia sp.}

VOUCher Material: El Diamante: 1 adult female (FMNH 203398); see table 5 for measurements.

IDENTIFICATION: This unnamed Carollia species was first recognized by Solari and Baker (2006) based on specimens from eastern Ecuador and northeastern Peru. We were unable to find any discrete morphological characteristic that would distinguish this unnamed species from $C$. benkeithi or C. castanea. Based on the analysis of cytochrome $b$ sequences, Velazco (2013) identified our specimen from El Diamante as a member of this unnamed taxon.

Remarks: Our only specimen of Carollia sp. was lactating. We continue to treat this as an unnamed taxon pending a more thorough revision of the genus.

\section{Subfamily Desmodontinae Wagner, 1840}

Three monotypic genera are recognized in this subfamily (Kwon and Gardner, 2008); two of these were recorded in the sampled localities.

\section{Desmodus rotundus \\ (É. Geoffroy St.-Hilaire, 1810)}

Voucher Material: El Diamante: 2 adult females (FMNH 203336; MUSM 39183), 8 adult males (FMNH 203332, 203334, 203516, 203518, 203520; MUSM 39184, 39185, 39186); Tingana: 1 adult female (MUSM 39187); Waqanki: 4 adult females (FMNH 203330, 203514; MUSM 39180, 30182), 1 adult male (MUSM 39181); see table 6 for measurements. 
TABLE 5

External and craniodental measurements $(\mathrm{mm})$ and weights $(\mathrm{g})$ of Carollia perspicillata and $C$. sp. nov.

\begin{tabular}{|c|c|c|c|}
\hline & \multicolumn{2}{|c|}{ Carollia perspicillata } & \multirow{2}{*}{$\begin{array}{l}\text { Carollia sp. nov. } \\
\text { FMNH } 203398 \text { ? }\end{array}$} \\
\hline & 20 males & 29 females & \\
\hline W & $16.6(13.0-18.0) 19$ & $15.4(11.0-20.0) 25$ & 38.5 \\
\hline TTL & $73.0(66.0-79.0) 20$ & $72.2(63.0-84.0) 29$ & 61.0 \\
\hline TL & $9.0(7.0-14.0) 20$ & $9.3(6.0-13.0) 29$ & 9.0 \\
\hline $\mathrm{HF}$ & $12.3(11.0-14.0) 20$ & $13.1(11.0-19.0) 29$ & 13.0 \\
\hline EL & $19.5(18.0-21.0) 20$ & $19.8(17.0-22.0) 29$ & 18.5 \\
\hline FA & $43.2(39.0-47.0) 20$ & $43.2(41.0-46.0) 29$ & 37.5 \\
\hline GLS & $22.1(20.9-23.3) 19$ & $21.9(21.0-22.9) 25$ & 19.2 \\
\hline CIL & $20.9(19.8-21.6) 19$ & $20.7(19.8-21.2) 25$ & 18.0 \\
\hline CCL & $20.2(19.0-20.9) 19$ & $20.0(19.1-20.6) 25$ & 17.4 \\
\hline LB & $5.9(5.6-6.1) 19$ & $5.9(5.6-6.3) 25$ & 5.4 \\
\hline РОВ & $5.6(5.1-5.9) 19$ & $5.5(5.2-5.8) 25$ & 5.4 \\
\hline ВСВ & $9.5(9.1-10.0) 19$ & $9.4(9.0-9.8) 25$ & 8.9 \\
\hline MB & $11.0(10.5-11.6) 19$ & $10.9(10.4-11.4) 25$ & 9.9 \\
\hline MTR & $7.6(7.3-7.9) 19$ & $7.5(6.7-8.1) 25$ & 6.5 \\
\hline BM & $7.8(7.1-8.3) 19$ & $7.8(7.2-8.3) 25$ & 6.9 \\
\hline $\mathrm{BC}$ & $5.0(4.6-5.4) 19$ & $4.8(4.4-5.1) 25$ & 4.3 \\
\hline
\end{tabular}

Identification: Descriptions and measurements of Desmodus rotundus have been provided by Goodwin and Greenhall (1961), Husson (1962), Swanepoel and Genoways (1979), Greenhall et al. (1983), and Simmons and Voss (1998). Currently two subspecies are recognized: $D . r$. murinus (northwestern Mexico southward to northern and western Colombia, and from the Pacific lowlands and western slopes of the Andes in Ecuador and Peru) and D. r. rotundus (Trinidad, Venezuela, Guianas, Amazon basin of Colombia, Ecuador, Peru, Brazil, and Bolivia, south through Paraguay and Uruguay into Chile and northern Argentina) (Kwon and Gardner, 2008). Our specimens conform in all respects to previous descriptions of $D$. rotundus: thumb greatly elongated, longer than hind foot, and with the presence of two basal pads; ventral sulcus present on tongue; inner lower incisors bicuspidate; and one upper molar on each side (Goodwin and Greenhall, 1961; Kwon and
Gardner, 2008; Cirranello et al., 2016). Our Mayo River basin voucher material belongs to the nominate subspecies.

Remarks: One female (FMNH 203336) that we collected was lactating.

\section{Diphylla ecaudata Spix, 1823}

Voucher Material: El Diamante: 1 adult female (MUSM 39188), 2 adult males (FMNH 203522; MUSM 39189); see table 6 for measurements.

IDENTIFICATION: Descriptions and measurements of Diphylla ecaudata have been provided by Swanepoel and Genoways (1979), Greenhall et al. (1984), and Kwon and Gardner (2008). Currently two subspecies are recognized: D. e. centralis (southern United States southward through eastern Mexico and Central America) and D.e. ecaudata (Venezuela, Colombia, Ecuador, Peru, Bolivia, and Brazil, excluding the central Amazon 
TABLE 6

External and craniodental measurements $(\mathrm{mm})$ and weights $(\mathrm{g})$ of Desmodus rotundus and Diphylla ecaudata

\begin{tabular}{|c|c|c|c|c|c|}
\hline & \multicolumn{2}{|c|}{ Desmodus rotundus } & \multicolumn{3}{|c|}{ Diphylla ecaudata } \\
\hline & 9 males & 7 females & FMNH 203522 శో & MUSM 39189 ઠే & MUSM 39188 우 \\
\hline W & $31.7(24.0-36.0) 9$ & $39.4(37.0-45.5) 7$ & 27.5 & 29.0 & 25.0 \\
\hline TTL & $81.9(78.0-85.0) 9$ & $90.6(86.0-95.0) 7$ & 85.0 & 83.0 & 86.0 \\
\hline $\mathrm{HF}$ & $17.0(15.0-19.0) 9$ & $16.6(14.0-20.0) 7$ & 14.0 & 13.0 & 17.0 \\
\hline EL & $18.8(17.0-20.0) 9$ & $18.9(16.0-20.0) 7$ & 13.0 & 13.0 & 17.0 \\
\hline FA & $61.9(60.0-64.0) 9$ & $65.3(65.0-67.0) 7$ & 54.0 & 53.0 & 53.0 \\
\hline GLS & $22.8(22.2-23.6) 8$ & $23.3(22.8-24.0) 5$ & 20.9 & 20.8 & 21.0 \\
\hline $\mathrm{CIL}$ & $22.3(21.7-23.0) 8$ & $22.9(22.5-23.2) 5$ & 20.6 & 20.0 & 20.0 \\
\hline CCL & $20.1(19.5-20.8) 8$ & $20.7(20.4-21.0) 5$ & 18.7 & 18.2 & 18.2 \\
\hline LB & $6.4(5.9-6.7) 8$ & $6.5(6.4-6.6) 5$ & 6.2 & 6.5 & 6.3 \\
\hline POB & $5.5(5.2-5.9) 8$ & $5.6(5.2-5.9) 5$ & 6.8 & 6.6 & 6.8 \\
\hline $\mathrm{ZB}$ & $12.3(11.7-13.0) 8$ & $12.5(12.1-12.8) 5$ & 12.9 & 12.1 & 12.5 \\
\hline $\mathrm{BCB}$ & $12.3(12.0-12.6) 8$ & $12.6(12.1-13.5) 5$ & 11.2 & 11.4 & 11.2 \\
\hline MB & $12.4(12.1-12.8) 8$ & $12.8(12.6-13.2) 5$ & 12.0 & 11.8 & 11.9 \\
\hline MTR & $3.7(3.5-3.8) 8$ & $3.7(3.4-3.8) 5$ & 3.3 & 3.8 & 3.6 \\
\hline $\mathrm{BM}$ & $6.1(5.6-6.4) 8$ & $6.6(6.4-6.9) 5$ & 5.7 & 5.8 & 5.6 \\
\hline $\mathrm{BC}$ & $6.1(5.8-6.4) 8$ & $6.3(6.0-6.4) 5$ & 5.2 & 5.3 & 5.3 \\
\hline
\end{tabular}

basin) (Greenhall et al., 1984; Kwon and Gardner, 2008). Our Mayo River basin specimens exhibit the diagnostic characteristics of the species: thumb small (usually less than $13 \mathrm{~mm}$ ), lacking basal pads; uropatagium well furred; occlusal margin of lower inner incisors with four lobes, of lower outer incisors with three lobes; two upper incisors and two lower molars on each side (Kwon and Gardner, 2008; Cirranello et al., 2016). Our Mayo River basin voucher material represents the nominate subspecies.

REMARKs: Our female (MUSM 39188) was lactating.

\section{Subfamily Glossophaginae Bonaparte, 1845}

A total of 14 genera and 35 species are currently recognized in this subfamily (Simmons, 2005; Griffiths and Gardner, 2008a; Nogueira et al., 2012). We recorded three species at the three sampled localities.

\section{Anoura caudifer (É. Geoffroy} St.-Hilaire, 1818)

Voucher Material: Tingana: 2 adult males (FMNH 203340; MUSM 39113); Waqanki: 4 adult females (FMNH 203338, 203526; MUSM 39111, 39112), 1 adult male (FMNH 203524); see table 7 for measurements.

Identification: Descriptions and measurements of Anoura caudifer have been provided by Husson (1962), Handley (1984), Molinari (1994), Simmons and Voss (1998), Mantilla-Meluk and Baker (2006), Brosset and Charles-Dominique (1990), and Pacheco et al. (2018). No subspecies are currently recognized in $A$. caudifer (Griffiths and Gardner, 2008a). Our Mayo River basin specimens exhibit the diagnostic characteristics of the species: well-developed calcar, slightly smaller than the foot; presence of a short tail; lower lip protruding less than $3 \mathrm{~mm}$ beyond upper lip; skull with keel along midline of mesopterygoid 
fossa that is not flattened posteriorly and usually extends onto septum between basisphenoid pits; and upper last premolar lacking medial internal cusp. Our vouchers fall within the range of measurements reported for A. caudifer.

Remarks: Two females (FMNH 203338, 203526) that we collected were pregnant, each with a single embryo (crown-rump length [CRL] $=20 \mathrm{~mm}$ ).

\section{Anoura geoffroyi Gray, 1838}

Voucher Material: Waqanki: 2 adult females (FMNH 203530; MUSM 39114), 2 adult males (FMNH 203528; MUSM 39115); see table 7 for measurements.

IDENTIFICATION: The review of the Anoura geoffroyi species complex by Mantilla-Meluk and Baker (2010) elevated the two nonnominal subspecies of $A$. geoffroyi to species rank: A. peruana (Tschudi, 1844) and A. lasiopyga (Peters, 1868). Based on the distributions provided by Mantilla-Meluk and Baker (2010), two Anoura species occur in Peru: A. peruana from the middle to high elevations of the Andes from Bolivia to Colombia, and A. geoffroyi from middle and low elevations of the eastern versant of the Andes from Brazil to northern South America, including the island of Trinidad. However, Pacheco et al. (2018) suggested that MantillaMeluk and Baker (2010) erroneously removed A. geoffroyi from the list of species present in Peru. Our Mayo River basin voucher material conforms with previous descriptions of $A$. geoffroyi, sharing the diagnostic characteristics of the species with specimens from Brazil (e.g., AMNH 78288, 78296; see below) and hence confirming presence of this species in Peru.

Descriptions and measurements of Anoura geoffroyi have been reported by Griffiths and Gardner (2008a) and Mantilla-Meluk and Baker (2010). No subspecies are currently recognized in A. geoffroyi sensu stricto (Mantilla-Meluk and Baker, 2010). The Mayo River basin specimens exhibit the diagnostic characteristics of the species: narrow uropatagium with a fringe of hair; lack of tail; zygomatic arches present; medial internal cusp of $\mathrm{P} 5$ prominently protruding from narrow base of tooth; upper and lower last two premolars narrow; and first lower premolar approximately the same size and shape as other lower premolars (Griffiths and Gardner, 2008a; Mantilla-Meluk and Baker, 2010).

\section{Glossophaga soricina (Pallas, 1766)}

Voucher Material: El Diamante: 1 adult female (MUSM 39193); Tingana: 1 adult male (FMNH 203536); Waqanki: 6 adult males (FMNH 203342, 203532, 203534; MUSM 3919039192); see table 7 for measurements.

IDENTIFICATION: Descriptions and measurements of Glossophaga soricina have been provided by Goodwin and Greenhall (1961), Husson (1962), Alvarez et al. (1991), Webster (1993), Simmons and Voss (1998), and Griffiths and Gardner (2008a). Currently five subspecies are recognized: G. s. antillarum (Jamaica), G. s. handleyi (northern Mexico southward to northern and western Colombia), G. s. mutica (Tres Marías Islands, Mexico), G. s. soricina (eastern Colombia, Ecuador, and Peru; Venezuela, Trinidad, Guyana, Suriname, French Guiana, Brazil, northern Bolivia, eastern Paraguay, and northern Argentina), and G. s. valens (western Ecuador and Peru, and eastward into the upper Marañon River of the Department of Amazonas, Peru) (Alvarez et al., 1991; Webster, 1993). G. soricina is easily distinguished from other species of the genus by craniodental features including: mandibular symphyseal ridge well developed; upper inner incisors large and procumbent, extending anteriorly well beyond upper outer incisors; M1 with well-developed parastyle; lower incisors crowded, usually in contact with each other and canines; and $\mathrm{m} 1$ and $\mathrm{m} 2$ with well-developed mesostyles (Alvarez et al., 1991; Webster, 1993; Griffiths and Gard- 


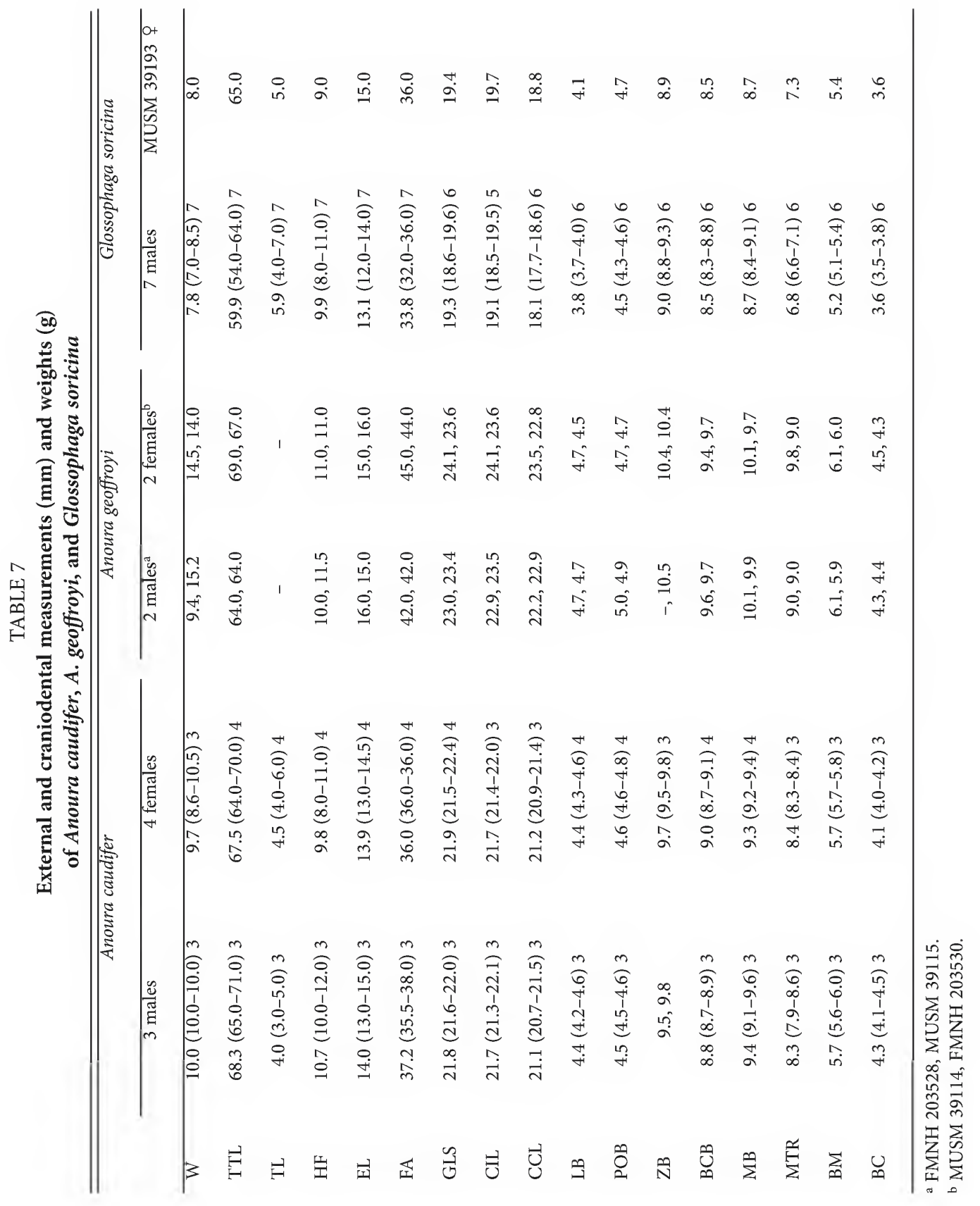


TABLE 8

External and craniodental measurements ( $\mathrm{mm}$ ) and weights (g) of Lionycteris spurrelli and Lonchophylla handleyi

\begin{tabular}{|c|c|c|c|c|}
\hline & \multicolumn{3}{|c|}{ Lionycteris spurrelli } & \multirow{2}{*}{$\frac{\text { Lonchophylla handleyi }}{\text { FMNH } 203346 \text { ơ }}$} \\
\hline & MUSM $39195 ð$ & FMNH 203538 ఠ & 5 females & \\
\hline W & 5.5 & - & $6.4(5.5-7.0) 5$ & 15.5 \\
\hline TTL & 53.0 & 59.0 & $59.6(56.0-63.0) 5$ & 81.0 \\
\hline TL & 8.0 & 5.0 & $6.6(6.0-8.0) 5$ & 5.0 \\
\hline $\mathrm{HF}$ & 9.0 & 9.0 & $10.4(9.0-12.0) 5$ & 12.0 \\
\hline EL & 11.0 & 12.0 & $11.4(8.0-13.0) 5$ & 16.0 \\
\hline FA & 33.0 & 34.0 & $35.2(35.0-36.0) 5$ & 42.0 \\
\hline GLS & 18.1 & 18.9 & $19.1(18.7-19.6) 5$ & 25.2 \\
\hline CIL & 17.4 & 18.6 & $18.8(18.4-19.4) 5$ & 25.6 \\
\hline CCL & 17.1 & 17.8 & $18.0(17.8-18.5) 5$ & 24.5 \\
\hline LB & 3.3 & 3.7 & $3.8(3.7-4.0) 5$ & 4.7 \\
\hline POB & 3.7 & 4.0 & $4.1(3.9-4.3) 5$ & 5.2 \\
\hline $\mathrm{BCB}$ & 7.9 & 8.2 & $8.1(7.9-8.5) 5$ & 10.0 \\
\hline MB & 8.1 & 8.3 & $8.4(8.2-8.6) 5$ & 11.0 \\
\hline MTR & 6.0 & 6.3 & $6.4(6.3-6.6) 5$ & 10.1 \\
\hline BM & - & 4.9 & $5.1(4.9-5.3) 5$ & 6.1 \\
\hline $\mathrm{BC}$ & 2.8 & 3.1 & $3.2(3.0-3.4) 5$ & 3.9 \\
\hline
\end{tabular}

ner, 2008a). Our Mayo River basin voucher material belongs to the nominate subspecies.

Subfamily Lonchophyllinae Griffiths, 1982

Twenty species are recognized in the five genera of this subfamily (Velazco et al., 2017). We recorded two species in the sampled localities.

\section{Lionycteris spurrelli Thomas, 1913}

Voucher Material: El Diamante: 5 adult females (FMNH 203344, 203540; MUSM 39194, 39196, 39197), 1 adult male (FMNH 203538), 1 juvenile male (MUSM 39195); see table 8 for measurements.

IDENTIFICATION: Descriptions and measurements of Lionycteris spurrelli have been provided by Phillips (1971), Carter and Dolan (1978),
Swanepoel and Genoways (1979), Williams and Genoways (1980), Koopman (1993), Zortéa et al. (1998), Gregorin and Ditchfield (2005), Woodman and Timm (2006), and Woodman (2007). No subspecies are currently recognized in L. spurrelli (Griffiths and Gardner, 2008b). Our specimens conform in all respects with previous descriptions of this species and exhibit the diagnostic characteristics of $L$. spurrelli: base of dorsal pelage darker than tips; GLS <21 mm; rostrum shorter than braincase; upper premolars not conspicuously elongated; well-developed lingual cusps present on both upper premolars; 44 and $\mathrm{p} 5$ short and broad; and main cusps of $\mathrm{p} 4$ and $\mathrm{p} 5$ high and narrow (Woodman and Timm, 2006; Griffiths and Gardner, 2008b). Our vouchers fall within the range of measurements reported for L. spurrelli.

Remarks: Two females (MUSM 39196, 39197) that we collected were lactating. 


\section{Lonchophylla handleyi Hill, 1980}

Voucher Material: Tarapoto: 1 subadult male (FMNH 203346); see table 8 for measurements.

IDENTIFICATION: Descriptions and measurements of Lonchophylla handleyi have been provided by Gardner (1976), Bowles et al. (1979), Hill (1980), Solari et al. (1999), Dávalos (2004), Woodman and Timm (2006), Woodman (2007), Dávalos and Corthals (2008), and Mantilla-Meluk et al. (2010). No subspecies are currently recognized in L. handleyi (Griffiths and Gardner, 2008b). Our specimen conforms in almost all respects to previous descriptions and exhibits the diagnostic characteristics of L. handleyi: fringe of hairs on the uropatagium; moderately inflated postorbital region; postorbital processes absent; posterior margin of infraorbital foramen located above the posterior root of P5; and weakly developed posterolingual cusp of P5 (Woodman and Timm, 2006; Griffiths and Gardner, 2008b). Because our specimen is a subadult, its measurements fall at the lower end or just outside the ranges previously reported for L. handleyi.

\section{Subfamily Phyllostominae Gray, 1825}

The subfamily Phyllostominae currently includes 22 species grouped into 10 genera (Baker et al., 2016; Cirranello et al., 2016). We recorded a single species at the sampled localities.

\section{Lophostoma silvicolum d'Orbigny, 1836}

Voucher Material: Waqanki: 1 adult male (FMNH 203542); see table 9 for measurements.

IDENTIFICATION: Descriptions and measurements of Lophostoma silvicolum have been provided by Swanepoel and Genoways (1979), Baker et al. (2004), Velazco and Cadenillas (2011), and Velazco and Gardner (2012). Currently three subspecies are recognized: L. s. centralis (eastern Honduras to Costa Rica), L. s. laephotis (Guianas to the lower Amazon basin of Brazil), and L. $s$. silvicolum (Panama through South America east of the Andes, in Bolivia, Brazil, Colombia, Ecuador, Paraguay, Peru, and Venezuela) (Williams and Genoways, 2008; Velazco and Cadenillas, 2011). L. silvicolum is distinguished from other species in the genus by the following combination of characteristics: large size (FA $>45 \mathrm{~mm}$, GLS > $4 \mathrm{~mm}$ ); brown to gray ventral fur; strong indentation present on the lingual cingulum of the upper canine; and M1 hypocone moderately to well developed (Velazco and Gardner, 2012).

Velazco and Cadenillas (2011) analyzed cytochrome $b$ sequences from all Lophostoma species, including our specimen (FMNH 203542). The specimens of $L$. silvicolum recovered from different localities throughout its range grouped into three clades. One of these clades was sister to L. evotis and contained specimens from Panama, Venezuela, eastern Ecuador, and eastern Peru (Mayo River basin). However, after reviewing more than 250 specimens of $L$. silvicolum throughout its entire distribution, Velazco and Cadenillas (2011) could not find a clear morphological or morphometric pattern that matched either the three molecular clades or the traditionally recognized subspecies. Before resolving this problem by making a taxonomic decision to either recognize the three subspecies as full species or, alternatively, lump the three subspecies and $L$. evotis together into one species, we believe that it is necessary to analyze nuclear and additional mitochondrial markers. Accordingly, here we simply refer our specimen to L. silvicolum as traditionally recognized. Our specimen conforms with previous descriptions and exhibits all the diagnostic characteristic of the species, and its measurements fall within the range previously documented for the species.

\section{Subfamily Rhinophyllinae Baker, Solari, Cirranello, and Simmons, 2016}

The lone genus recognized in this subfamily contains three species (McLellan and Koopman, 2008; Baker et al., 2016; Cirranello et al., 2016). 
TABLE 9

External and craniodental measurements ( $\mathrm{mm}$ ) and weights (g) of Lophostoma silvicolum and Rhinophylla pumilio

\begin{tabular}{|c|c|c|c|}
\hline & \multirow{2}{*}{$\begin{array}{c}\text { Lophostoma silvicolum } \\
\text { FMNH } 203542 \delta\end{array}$} & \multicolumn{2}{|c|}{ Rhinophylla pumilio } \\
\hline & & 4 males & 10 females \\
\hline W & 25.0 & $9.2(8.5-10.0) 4$ & $9.6(8.2-11.0) 10$ \\
\hline TTL & 104.0 & $52.0(49.0-55.0) 4$ & $52.2(49.0-55.0) 10$ \\
\hline TL & 21.0 & -- & -- \\
\hline $\mathrm{HF}$ & 15.0 & $8.0(5.0-11.0) 4$ & $9.5(8.0-11.0) 10$ \\
\hline EL & 37.0 & $15.0(14.0-16.0) 4$ & $16.1(15.0-17.0) 10$ \\
\hline FA & 57.0 & $34.3(33.0-35.0) 4$ & $35.0(34.0-36.0) 9$ \\
\hline GLS & 26.7 & $18.2(17.8-18.4) 4$ & $18.2(17.5-18.7) 10$ \\
\hline CIL & 23.7 & $16.9(16.7-17.2) 4$ & $17.0(16.4-17.6) 10$ \\
\hline CCL & 23.1 & $16.2(16.0-16.4) 4$ & $16.2(15.7-16.7) 10$ \\
\hline LB & 6.2 & $4.9(4.8-5.0) 4$ & $4.8(4.7-5.1) 10$ \\
\hline POB & 4.0 & $5.4(5.2-5.5) 4$ & $5.3(5.1-5.5) 10$ \\
\hline ZB & 12.9 & -- & -- \\
\hline $\mathrm{BCB}$ & 11.0 & $8.3(8.2-8.4) 4$ & $8.2(8.0-8.4) 10$ \\
\hline MB & 13.6 & $9.2(9.1-9.2) 4$ & $9.2(8.9-9.4) 10$ \\
\hline MTR & 9.7 & $5.1(5.1-5.2) 4$ & $5.2(4.9-5.5) 10$ \\
\hline $\mathrm{BM}$ & 8.7 & $6.5(6.3-6.7) 4$ & $6.5(5.8-6.9) 10$ \\
\hline $\mathrm{BC}$ & 6.2 & $4.7(4.6-4.8) 4$ & $4.7(4.5-5.0) 10$ \\
\hline
\end{tabular}

One species was recorded in two of the three sampled localities.

\section{Rhinophylla pumilio Peters, 1865}

Voucher Material: Tingana: 6 adult females (FMNH 203402, 203404, 203406; MUSM 39219-39221), 2 adult males (MUSM 39218, 39222); Waqanki: 4 adult females (FMNH 203400, 203580; MUSM 39216, 39217), 2 adult males (FMNH 203578; MUSM 39215); see table 9 for measurements.

IDENTIFICATION: Descriptions and measurements of Rhinophylla pumilio have been provided by Swanepoel and Genoways (1979), Anderson (1997), Simmons and Voss (1998), Rinehart and Kunz (2006), and McLellan and Koopman (2008).
No subspecies are currently recognized in $R$. pumilio (McLellan and Koopman, 2008). Our specimens conform in all respects to previous descriptions and show the characteristics described for the species: margin of uropatagium naked; upper inner incisors relatively broad and with three or four well-defined lobes; and gap absent between upper incisor and canine. Measurements of our vouchers fall within the ranges reported for R. pumilio.

Remarks: Two females (FMNH 203400, 203404) that we collected were lactating.

\section{Subfamily Stenodermatinae Gervais, 1856}

Ninety-eight species grouped into 19 genera are currently recognized in the subfamily Stenodermatinae (Simmons, 2005; Taddei and Lim, 2010; 


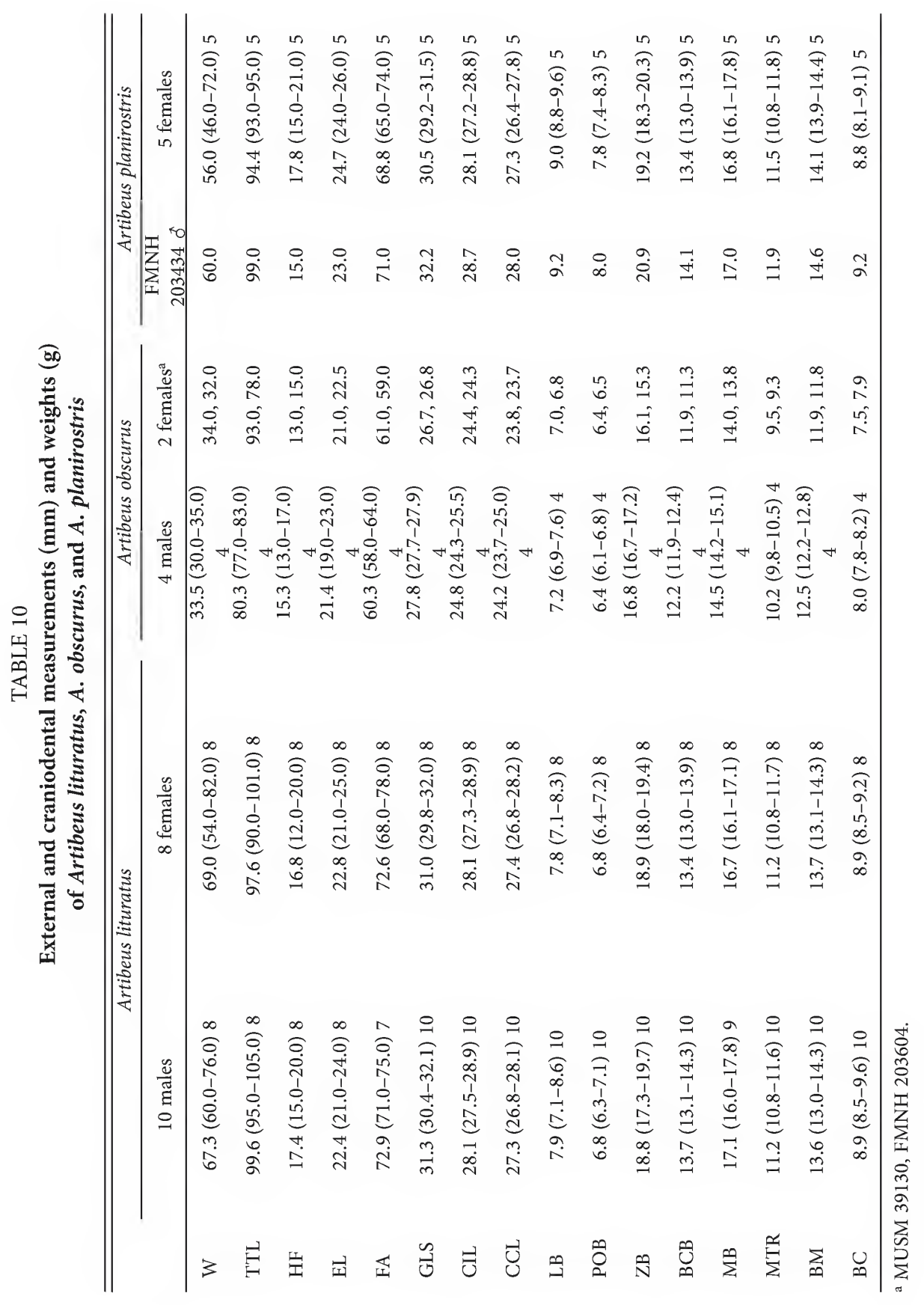


TABLE 11

External and craniodental measurements ( $\mathrm{mm}$ ) and weights (g) of Artibeus anderseni and A. glaucus

\begin{tabular}{|c|c|c|c|c|}
\hline & \multicolumn{2}{|c|}{ Artibeus anderseni } & \multicolumn{2}{|c|}{ Artibeus glaucus } \\
\hline & 2 males $^{\mathrm{a}}$ & 3 females & 4 males & 3 females \\
\hline W & $9.0,11.0$ & $11.0(9.4-12.0) 3$ & $10.8(10.0-12.0) 3$ & $11.7(11.0-12.0) 3$ \\
\hline TTL & $52.0,54.0$ & $54.0(50.0-58.0) 3$ & $57.3(54.0-61.0) 4$ & $55.3(51.0-58.0) 3$ \\
\hline $\mathrm{HF}$ & $10.0,10.0$ & $10.2(9.0-11.5) 3$ & $9.8(9.0-11.0) 4$ & $10.3(9.0-12.0) 3$ \\
\hline EL & $14.0,16.0$ & $15.2(14.0-16.0) 3$ & $14.8(13.0-16.0) 4$ & (16) 3 \\
\hline FA & $35.0,38.0$ & $39.3(39.0-40.0) 3$ & $40.5(39.0-42.0) 4$ & $42.2(42.0-42.5) 3$ \\
\hline GLS & $17.7,18.6$ & $18.6(18.1-19.0) 3$ & $19.5(19.2-19.9) 4$ & $19.9(19.5-20.3) 3$ \\
\hline CIL & $16.2,16.8$ & $16.8(16.6-17.3) 3$ & $17.8(17.5-18.0) 4$ & $18.2(17.9-18.5) 3$ \\
\hline $\mathrm{CCL}$ & $15.8,16.4$ & $16.6(16.2-17.1) 3$ & $17.4(17.1-17.8) 4$ & $17.8(17.5-18.1) 3$ \\
\hline LB & $4.6,5.0$ & $5.1(4.9-5.5) 3$ & $5.8(5.4-6.0) 4$ & $5.8(5.7-6.0) 3$ \\
\hline РОВ & $4.6,4.9$ & $4.8(4.7-5.0) 3$ & $5.3(5.2-5.3) 4$ & $5.1(5.0-5.2) 3$ \\
\hline $\mathrm{ZB}$ & $10.8,11.5$ & $11.3(11.2-11.5) 3$ & $11.3(11.1-11.7) 4$ & $11.5(11.3-11.7) 3$ \\
\hline $\mathrm{BCB}$ & $8.1,8.9$ & $8.7(8.5-9.0) 3$ & $9.0(8.7-9.2) 4$ & $8.9(8.7-9.1) 3$ \\
\hline MB & $9.2,9.8$ & $9.8(9.6-10.1) 3$ & $10.1(10.0-10.3) 4$ & $10.2(10.1-10.3) 3$ \\
\hline MTR & $5.6,5.8$ & $5.8(5.7-6.1) 3$ & $6.5(6.4-6.6) 4$ & $6.3(6.0-6.5) 3$ \\
\hline $\mathrm{BM}$ & $7.8,8.1$ & $8.1(7.9-8.2) 3$ & $8.3(8.1-8.4) 4$ & $8.3(7.9-8.6) 3$ \\
\hline $\mathrm{BC}$ & $5.3,5.0$ & $5.1(5.0-5.2) 3$ & $5.4(5.3-5.8) 4$ & $5.4(5.2-5.6) 3$ \\
\hline
\end{tabular}

a FMNH 203438, MUSM 39118.

Velazco et al., 2010; Mantilla-Meluk, 2014; Tavares et al., 2014; Velazco and Lim, 2014; Baker et al., 2016; Cirranello et al., 2016; Molinari et al., 2017). We recorded 14 species at the sampled localities, including an undescribed species of Sturnira.

\section{Artibeus Leach, 1821}

The genus Artibeus currently includes 23 species grouped into two subgenera (Artibeus and Dermanura) (Hoofer et al., 2008; Redondo et al., 2008; Solari et al., 2009; Cirranello et al., 2016). For decades there has been controversy regarding whether three genera (Artibeus, Dermanura, and Koopmania), two genera (Artibeus and Dermanura), or only one genus (Artibeus) should be recognized to group these species. Recently Cirranello et al. (2016) and Baker et al. (2016) advocate for the recognition of a single genus with two subgenera (Artibeus and Dermanura) as the most reasonable classification scheme for these taxa. Five Artibeus species were recorded at the three sampled localities.

Artibeus (Artibeus) lituratus (Olfers, 1818)

Voucher Material: El Diamante: 1 adult female (MUSM 39125); Tingana: 4 adult females (FMNH 203426, 203600, 203602; MUSM 39126), 6 adult males (FMNH 203428, 203430, 203598; MUSM 39127-39129); Waqanki: 3 adult females (FMNH 203424; MUSM 39123, 39124), 4 adult males (FMNH 203422, 203594, 203596; MUSM 39122); see table 10 for measurements.

IDENTIFICATION: We consulted descriptions and measurements of Artibeus lituratus provided by Goodwin and Greenhall (1961), Swanepoel and Genoways (1979), Davis (1984), Koepcke and Kraft (1984), Handley (1987), Brosset and Charles-Dom- 
inique (1990), Marques-Aguiar (1994), Anderson (1997), Simmons and Voss (1998), Rui et al. (1999), and Marchan-Rivadeneira et al. (2012). Currently, two subspecies are recognized: A. l. lituratus (south of the Orinoco basin in Venezuela, east through the Guianas and southward, east of the Andes in Colombia, Ecuador, Brazil, Peru, and Bolivia into Paraguay and northern Argentina) and A. l. palmarum (southeastern Mexico south to northern and western Colombia, northern Venezuela, Trinidad and Tobago, and Lesser Antilles) (Marques-Aguiar, 2008; Larsen et al., 2013). Our Mayo River basin specimens exhibit the diagnostic characteristics of the species: large size (FA >63); brown dorsal and ventral pelage; ventral pelage without silver frosting; well-defined white facial stripes; dorsal surface of uropatagium furred; M1 with weakly developed hypocone; and M3 absent (Marques-Aguiar, 2008; Larsen et al., 2013). Measurements of the Mayo River specimens fall within the ranges reported for the nominate subspecies.

REMARKs: One female (MUSM 39124) that we collected was lactating.

\section{Artibeus (Artibeus) obscurus (Schinz, 1821)}

Voucher Material: Tingana: 2 adult females (FMNH 203604; MUSM 39130), 4 adult males (FMNH 203432; MUSM 39131-39133); see table 10 for measurements.

IDENTIFICATION: We consulted descriptions and measurements of Artibeus obscurus (under the name A. fuliginosus in earlier publications) provided by Koepcke and Kraft (1984), Handley (1987), Brosset and Charles-Dominique (1990), Lim and Wilson (1993), Marques-Aguiar (1994), Simmons and Voss (1998), Haynes and Lee (2004), and Lim et al. (2005). No subspecies are currently recognized in A. obscurus (Marques-Aguiar, 2008). Our Mayo River basin specimens exhibit the diagnostic characteristics of the species: medium size (FA 55-69 mm); dorsal pelage blackish and long (8-10 mm); facial stripes pale or obsolete; M3 variably present (Haynes and Lee, 2004; Marques-
Aguiar, 2008). Measurements of our specimens fall within the ranges reported for the species.

\section{Artibeus (Artibeus) planirostris (Spix, 1823)}

Voucher Material: El Diamante: 2 adult females (FMNH 203608; MUSM 39135); Tingana: 1 adult female (FMNH 203436); Waqanki: 2 adult females (FMNH 203606; MUSM 39134), 1 adult male (FMNH 203434); see table 10 for measurements.

IDENTIFICATION: We consulted descriptions and measurements of Artibeus planirostris provided by Husson (1962, 1978), Patten (1971), Handley (1987), Brosset and Charles-Dominique (1990), Lim and Wilson (1993), Lim (1997), Hollis (2005), and Lim et al. (2005). Currently three subspecies are recognized: A. p. fallax (Venezuela [south and east of the Orinoco river]), Trinidad, Grenada, Guyana, Surinam, French Guiana, and the lower Amazon basin of Brazil), A. p. hercules (southeastern Colombia and the eastern lowlands of Ecuador, Peru, and Bolivia), and A. p. planirostris (southern Bolivia, northern Argentina, Paraguay, and eastern and southern Brazil) (Marques-Aguiar, 2008). The only major morphological difference recognized among subspecies is that $A$. p. hercules tends to be larger than the other subspecies (Hollis, 2005). Based on distribution, the voucher material from Mayo River basin should correspond to the subspecies A. p. hercules. However, measurements of our material span the published variation of size for the entire species, and hence do not conform to published characteristics of the subspecies. We therefore recommend against formally recognizing subspecies in Artibeus planirostris until truly diagnostic characters can be found, including additional data from molecular markers.

\section{Subgenus Dermanura Gervais, 1856}

Small-sized Artibeus (Dermanura) species are difficult to unequivocally identify based solely on external morphology (Simmons and 
TABLE 12

External and craniodental measurements $(\mathrm{mm})$ and weights $(\mathrm{g})$ of Chiroderma trinitatum and Mesophylla macconnelli

\begin{tabular}{lcccc}
\hline \hline & Chiroderma trinitatum & & \multicolumn{2}{c}{ Mesophylla macconnelli } \\
\cline { 2 - 2 } MUSM 39179 o & FMNH 203618 oे & MUSM 39198 oे \\
\hline TTL & 12.0 & 5.5 & 6.4 \\
HF & 60.0 & 48.0 & 49.0 \\
EL & 10.0 & 8.0 & 9.0 \\
FA & 15.0 & 14.0 & 14.0 \\
GLS & 42.0 & 31.0 & 31.0 \\
CIL & 21.3 & 17.9 & 17.4 \\
CCL & 19.8 & 16.1 & 15.9 \\
LB & 19.2 & 15.7 & 15.4 \\
POB & 5.7 & 4.3 & 4.3 \\
ZB & 5.4 & 4.4 & 4.4 \\
BCB & 13.1 & 10.4 & 10.1 \\
MB & 9.8 & 8.1 & 7.7 \\
MTR & 11.0 & 9.3 & 8.8 \\
BM & 7.1 & 6.0 & 6.0 \\
BC & 9.6 & 7.3 & 7.0 \\
\hline
\end{tabular}

Voss, 1998). The majority of the external characteristics proposed to differentiate species of Dermanura are highly variable within and among species (e.g., see discussion in Simmons and Voss, 1998). In order to positively identify all our voucher specimens of the subgenus Dermanura, we sequenced a fragment of the mitochondrial cytochrome $b$ gene and compared it with the sequences published by Solari et al. (2009). The molecular analysis of our sequences grouped our specimens into two species: $A$. anderseni and A. glaucus.

\section{Artibeus (Dermanura) anderseni Osgood, 1916}

Voucher Material: Tingana: 2 adult males (FMNH 203438; MUSM 39118); Waqanki: 3 adult females (FMNH 203610; MUSM 39116, 39117); see table 11 for measurements.
Identification: We consulted descriptions and measurements of Artibeus anderseni provided by Webster and Jones (1980), Anderson (1997), and Rocha et al. (2018). No subspecies are currently recognized (Marques-Aguiar, 2008). Our Mayo River basin voucher specimens exhibit the diagnostic characteristics of the species: uropatagium sparsely haired; rostrum elevated (tilted up); weakly developed impression of the optic nerve in the orbit; maxillary toothrow nearly parallel; caniniform P5; broad talon on M1; and presence of two lower molars (MarquesAguiar, 2008; Díaz et al., 2016; Rocha et al., 2018). Measurements of our specimens fall within the ranges previously reported for the species.

REMARKs: One female (MUSM 39116) that we collected was lactating. 


\section{Artibeus (Dermanura) glaucus Thomas, 1893}

VOUCher Material: El Diamante: 1 adult female (FMNH 203616), 2 adult males (FMNH 203614; MUSM 39120); Tingana: 1 adult female (MUSM 39121); Waqanki: 1 adult female (FMNH 203612), 2 adult males (FMNH 203440; MUSM 39119); see table 11 for measurements.

IDENTIFICATION: We consulted descriptions and measurements of Artibeus glaucus provided by Andersen (1908), Davis (1970), Carter and Dolan (1978), Swanepoel and Genoways (1979), Anderson (1997), Lim et al. (2008), and Ortega et al. (2015). No subspecies are currently recognized in A. glaucus (Lim et al., 2008). Our Mayo River basin specimens exhibit the diagnostic characteristics of the species: dark gray to blackish dorsal pelage; dark ears; V-shaped posterior margin of uropatagium; rostrum not elevated with a concavity present dorsally; U-shaped posterior border of the hard palate; mesopterygoid fossa not constricted posteriorly on basicranium; well-developed angular process reaching the level of the condyloid process; and presence of three lower molars (Marques-Aguiar, 2008; Díaz et al., 2016). Measurements of our specimens fall within the range reported for the species.

Remarks: One female (FMNH 203616) that we collected was lactating.

\section{Chiroderma trinitatum Goodwin, 1958}

Voucher Material: Waqanki: 1 adult male (MUSM 39179); see table 12 for measurements.

IDENTIFICATION: We consulted descriptions and measurements of Chiroderma trinitatum provided by Goodwin (1958), Goodwin and Greenhall (1961), Baker and Genoways (1976), Gardner (1976), Carter and Dolan (1978), Genoways and Williams (1979), Swanepoel and Genoways (1979), Brosset and Charles-Dominique (1990), Anderson (1997), Simmons and
Voss (1998), Lim et al. (2005), Taddei and Lim (2010), Garbino et al. (2012), Tello et al. (2014), and Rocha et al. (2016). Two subspecies are currently recognized: C. $t$. gorgasi (Panama south to western Colombia and northwestern Ecuador) and C. $t$. trinitatum (Trinidad, eastern Colombia, Ecuador, and Peru, and Venezuela, the Guianas, Brazil, and northern Bolivia) (Gardner, 2008c). Our Mayo River basin specimen exhibits the diagnostic characteristics of the nominate subspecies: small size (FA $<42.5 \mathrm{~mm}$, GLS $<23 \mathrm{~mm}$ ); dorsal stripe arising between the shoulders and extending across the head; muzzle short and broad; furred legs; uropatagium partially furred, lack of a conspicuous fringe of hair on its trailing edge; skull lacking nasal bones; and upper inner incisors that converge along their distal third, contacting each other at the tips (Simmons and Voss, 1998; Gardner, 2008c; Garbino et al., 2012). Measurements of our specimen fall within the range reported for the species.

\section{Mesophylla macconnelli Thomas, 1901}

Voucher Material: Tingana: 1 adult male (FMNH 203618); Waqanki: 1 adult male (MUSM 39198); see table 12 for measurements.

IDENTIFICATION: We consulted descriptions and measurements of Mesophylla macconnelli provided by Goodwin and Greenhall (1962), Ceballos Bendezú (1968), Starrett and Casebeer (1968), Carter and Dolan (1978), Swanepoel and Genoways (1979), Brosset and Charles-Dominique (1990), Anderson (1997), and Simmons and Voss (1998). No subspecies are currently recognized in M. macconnelli (Arroyo-Cabrales, 2008a). Our Mayo River basin specimens exhibit the diagnostic characteristics of the species: small size (FA 28-34 mm); ears and noseleaf yellow in live specimens, but paler in museum specimens; small accessory noseleaflike structure present behind the noseleaf; skull short with a relatively narrow rostrum; palate extending well 
behind the last molars; upper inner incisors long, convergent, and usually with weakly bifid tips; $\mathrm{m} 2$ lacking a posterior cuspulid; and minute m3 (Arroyo-Cabrales, 2008a). Measurements of our specimens fall within the range reported for the species.

\section{Platyrrhinus incarum (Thomas, 1912)}

Voucher Material: Waqanki: 4 adult females (FMNH 203624, 203626; MUSM 39199, 39200), 7 adult males (FMNH 203442, 203620, 203622; MUSM 39201-39204); see table 13 for measurements.

IDENTIFICATION: We consulted descriptions and measurements of Platyrrhinus incarum provided by Anderson (1997), Velazco et al. (2010), and Velazco and Lim (2014). No subspecies are currently recognized in $P$. incarum (Velazco et al., 2010). Velazco et al. (2010) identified all the material from Mayo River basin as P. incarum. Our Mayo River basin specimens exhibit the diagnostic characteristics of the species: small size (FA 35-40 mm); poorly developed (almost imperceptible) paraoccipital processes; barely perceptible fossa on the squamosal root of the zygomatic arch; two stylar cuspules on the posterior cristid of $\mathrm{P} 4$; M1 protocone well developed; stylar cuspule present on lingual face of the paracone of M2; and $\mathrm{m} 2$ hypoconid present (Velazco et al., 2010). Measurements of our specimens fall within the range previously reported for the species.

\section{Platyrrhinus infuscus (Peters, 1880)}

Voucher Material: El Diamante: 5 adult females (FMNH 203452, 203634, 203638; MUSM 39213, 39214), 5 adult males (FMNH 203450, 203454, 203636; MUSM 39211, 39212); Waqanki: 4 adult females (FMNH 203630, 203632; MUSM 39206, 39209), 8 adult males (FMNH 203444, 203446, 203448, 203628; MUSM 39205, 39207, 39208,39210 ); see table 13 for measurements.
IDENTIFICATION: We consulted descriptions and measurements of Platyrrhinus infuscus provided by Cabrera (1958), Gardner and Carter (1972), Swanepoel and Genoways (1979), Velazco (2005), and Velazco and Gardner (2009). No subspecies are currently recognized in $P$. infuscus (Gardner, 2008d). Our Mayo River basin specimens exhibit the diagnostic characteristics of the species: larger size (FA >54 mm); dark brown dorsal pelage; facial and dorsal stripes inconspicuous; short, sparse hair on the upper surface of feet; posterolabial cuspulid present on p5; M1 parastyle present; and $\mathrm{m} 1$ metaconid well developed (Velazco, 2005; Gardner, 2008d). Measurements of our specimens fall within the range reported for the species.

\section{Sturnira Gray, 1842}

The genus Sturnira currently includes 23 described species and one unnamed form, making it the most speciose phyllostomid genus (Velazco and Patterson, 2013; Velazco and Patterson, 2014; Molinari et al., 2017). A multilocus phylogenetic analysis of the genus by Velazco and Patterson (2013) identified three unnamed taxa. Two of these were subsequently described by Velazco and Patterson (2014) as S. bakeri and S. burtonlimi. The third, "S[turnira]. new species 3," long confused with and considered part of $S$. lilium, is described below. It is one of the most widely distributed species in the genus. Three Sturnira species were recorded at the three sampled localities.

\section{Sturnira giannae, new species}

Gianna's Yellow-Shouldered Bat

Murciélago de Charreteras de Gianna

Sturnira lilium: Dobson 1878: 540 (part).

Sturnira lilium lilium: Cabrera 1958: 78 (part). S[turnira]. new species 3: Velazco and Patterson 2013: 687.

Holotype: The holotype (AMNH 268545; fig. 2 , table 14 ), an adult male specimen preserved in 
TABLE 13

External and craniodental measurements $(\mathrm{mm})$ and weights $(\mathrm{g})$ of Platyrrhinus incarum, P. infuscus, and Sturnira oporaphilum

\begin{tabular}{|c|c|c|c|c|c|}
\hline & \multicolumn{2}{|c|}{ Platyrrhinus incarum } & \multicolumn{2}{|c|}{ Platyrrhinus infuscus } & \multirow{2}{*}{$\frac{\text { Sturnira oporaphilum }}{\text { MUSM } 39230 \delta}$} \\
\hline & 7 males & 4 females & 13 males & 9 females & \\
\hline $\mathrm{W}$ & $12.1(11.1-13.0) 7$ & $14.3(12.6-15.6) 3$ & $37.0(31.5-43.0) 12$ & $38.3(30.0-42.0) 8$ & 16.4 \\
\hline TTL & $57.7(54.0-62.0) 7$ & $61.3(57.0-66.0) 4$ & $87.5(82.0-91.0) 13$ & $85.9(81.0-90.0) 9$ & 70.0 \\
\hline $\mathrm{HF}$ & $10.6(9.0-12.0) 7$ & $10.8(10.0-11.0) 4$ & $14.1(12.0-16.0) 13$ & $15.0(10.0-18.0) 9$ & 11.0 \\
\hline EL & $15.6(15.0-17.0) 7$ & $15.8(15.0-17.0) 4$ & $20.7(18.0-23.0) 13$ & $21.7(17.0-23.0) 9$ & 18.0 \\
\hline FA & $37.7(36.0-39.0) 7$ & $39.3(38.0-40.0) 4$ & $57.3(55.0-60.0) 13$ & $59.0(57.0-61.0) 9$ & 44.0 \\
\hline GLS & $20.7(20.0-21.1) 7$ & $20.8(20.6-21.0) 4$ & $29.7(28.9-30.8) 11$ & $29.4(27.9-30.2) 9$ & 22.8 \\
\hline CIL & $18.9(18.4-19.4) 7$ & $19.1(18.9-19.3) 4$ & $27.5(26.8-28.7) 11$ & $27.4(26.2-28.4) 9$ & 21.4 \\
\hline CCL & $18.5(18.0-18.9) 7$ & $18.7(18.4-18.9) 4$ & $26.8(26.3-27.9) 11$ & $26.9(25.6-27.9) 9$ & 20.6 \\
\hline LB & $5.4(5.2-5.8) 7$ & $5.5(5.4-5.5) 4$ & $7.3(6.6-7.7) 11$ & $7.3(7.0-7.7) 9$ & -- \\
\hline РОВ & $5.3(5.0-5.5) 7$ & $5.4(5.3-5.7) 4$ & $6.8(6.5-7.0) 11$ & $6.7(6.3-7.0) 9$ & 6.0 \\
\hline $\mathrm{ZB}$ & $11.9(11.7-12.2) 7$ & $12.3(12.1-12.8) 3$ & $17.8(17.3-18.4) 11$ & $17.6(16.5-18.2) 9$ & 13.4 \\
\hline ВСВ & $9.2(8.8-9.5) 7$ & $9.3(9.2-9.3) 4$ & $12.5(12.1-12.8) 11$ & $12.3(12.0-12.7) 9$ & 10.3 \\
\hline MB & $10.3(10.1-10.5) 7$ & $10.8(10.4-11.2) 4$ & $14.8(14.2-15.3) 11$ & $14.7(14.1-15.2) 9$ & 12.3 \\
\hline MTR & $7.2(6.9-7.5) 7$ & $7.3(7.3-7.4) 4$ & $11.6(11.2-11.9) 11$ & $11.6(11.1-11.9) 9$ & 6.9 \\
\hline BM & $8.5(8.2-8.7) 7$ & $8.7(8.4-8.9) 4$ & $13.3(12.7-13.7) 11$ & $13.2(12.4-13.8) 9$ & 7.8 \\
\hline $\mathrm{BC}$ & $5.0(4.8-5.2) 7$ & $5.2(5.0-5.3) 4$ & $8.0(7.7-8.2) 11$ & $7.7(7.4-8.5) 9$ & 6.3 \\
\hline
\end{tabular}

alcohol with the skull removed and cleaned, was collected by Nancy B. Simmons (original field number 846) on 8 October 1994 at Paracou $\left(5^{\circ} 17^{\prime} \mathrm{N}, 53^{\circ} 55^{\prime} \mathrm{W}, 210 \mathrm{~m}\right)$, near Sinnamary, Cayenne, French Guiana. The body and skull are in good condition. Frozen tissues are deposited at the Ambrose Monell Cryo Collection at the American Museum of Natural History (AMCC 110416).

Paratypes: An adult female (FMNH 203582) caught by Paúl M. Velazco (original field number PMV 2295) collected on 2 May 2007 at the Waqanki locality. An adult female (MUSM 13260) caught by Robert S. Voss (original field number RSV 2365) collected on 5 July 1998 at Nuevo San Juan $\left(73^{\circ} 9^{\prime} 50^{\prime \prime} \mathrm{W}, 5^{\circ} 14^{\prime} 50^{\prime \prime} \mathrm{S}\right.$; $150 \mathrm{~m}$ above sea level), a Matses village on the right (SE) bank of the Río Gálvez in the Peruvian department of Loreto. Frozen tissues are deposited at the Ambrose Monell Cryo Collec- tion of the American Museum of Natural History (AMCC 109783). An adult male (MUSM 39228) caught by Richard Cadenillas (original field number RCO 965) collected on 14 May 2007 at El Diamante locality (table 14). Frozen tissues of FMNH 203582 and MUSM 39228 are deposited at the Field Museum of Natural History.

Distribution: Eastern slopes of the Andes and adjacent Amazonian lowlands from Colombia to northern Bolivia. Lowlands of southern Venezuela, the Guianas, and Brazilian Amazon (fig. 3; appendix). One specimen of Sturnira giannae (FMNH 128845) was collected at a locality (fig. 3: 19) on the western slope of the Andes in the department of Cajamarca, Peru. This record could result from populations of $S$. giannae using the Huancabamba Depression, which features the lowest montane passes in the 
TABLE 14

External and craniodental measurements $(\mathrm{mm})$ and weights (g) of the type series of Sturnira giannae

\begin{tabular}{lcccc}
\hline \hline & $\begin{array}{c}\text { Holotype } \\
\text { AMNH }\end{array}$ & $\begin{array}{c}\text { Paratype } \\
\text { FMNH }\end{array}$ & $\begin{array}{c}\text { Paratype } \\
\text { MUSM }\end{array}$ & $\begin{array}{c}\text { Paratype } \\
\text { MUSM }\end{array}$ \\
\hline W6855 o & 203582 o & 13260 \% & 39228 o \\
\hline TTL & 25.3 & 14.0 & 18.0 & 22.0 \\
HF & 73.0 & 67.0 & 65.0 & 73.0 \\
EL & 15.0 & 13.0 & 13.0 & 12.0 \\
FA & 17.0 & 16.0 & 17.0 & 14.0 \\
GLS & 45.0 & 45.0 & 45.0 & 44.0 \\
CIL & 22.7 & 22.6 & 22.3 & 22.2 \\
CCL & 21.2 & 21.3 & 20.6 & 21.2 \\
POB & 20.4 & 20.4 & 19.9 & 20.5 \\
ZB & 6.1 & 5.8 & 5.5 & 6.1 \\
BCB & 14.4 & 14.0 & 13.2 & 13.9 \\
MB & 10.5 & 10.4 & 9.8 & 10.3 \\
MTR & 12.7 & 12.2 & 11.5 & 11.9 \\
BM & 6.6 & 6.8 & 6.8 & 6.8 \\
DENL & 8.1 & 14.8 & 8.2 & 8.3 \\
MANDL & 15.2 & 7.8 & 7.6 & 15.0 \\
\hline & 7.5 & & 7.6 & 7.7 \\
\hline
\end{tabular}

Andes between Venezuela and Chile, as a corridor to cross the Andes.

Eтymology: The epithet giannae, a feminine noun in the genitive case, is proposed in dedication to the daughter of the first author, Gianna C. Velazco Kline.

DiAgnosis: Dorsal fur short and bicolored with pale brown bases ( $80 \%$ of length) and dark brown tips. Ventral fur short and monocolored. Shoulder glands (epaulettes) present in both sexes, but variable in the degree of development. Trailing edge of the uropatagium covered by short hairs. Sphenorbital fissure small. Zygomatic arches do not converge anteriorly. Anterior process of glenoid fossa well developed. Upper inner incisor (I1) bicuspidate and slender. First and second lower incisors (i1 and i2) tricuspidate and subequal in height. Paraconid present and well developed in $\mathrm{m} 1$ but absent in $\mathrm{m} 2$. Metaconids and entoconids of $\mathrm{m} 1, \mathrm{~m} 2$, and $\mathrm{m} 3$ well defined and separated by a deep notch.

DESCRIPTION: Sturnira giannae is a mediumsized yellow-shouldered bat (FA 43.0-47.0 mm; GLS 21.7-24.2 mm; CIL 20.1-21.8 mm; fig. 4, tables 14-15) with a slender rostrum and a globular braincase (fig. 2). The dorsal pelage is brown to reddish brown (fig. 4). Dorsal hairs are bicolored with a long, pale brown base (approximately $80 \%$ of the length of each hair), and a short, darkbrown terminal band (approximately $20 \%$ of each hair). The ventral pelage is brown to reddish brown (fig. 4). Ventral hairs are monocolored and vary from gray to pale brown. The fur is short, 5-6 $\mathrm{mm}$ long between the shoulders and $4 \mathrm{~mm}$ on the chest. Shoulder glands (epaulettes) are present in both sexes with varying degrees of definition: weakly defined in some specimens (e.g., FMNH 203588) and strongly so in others (MUSM 


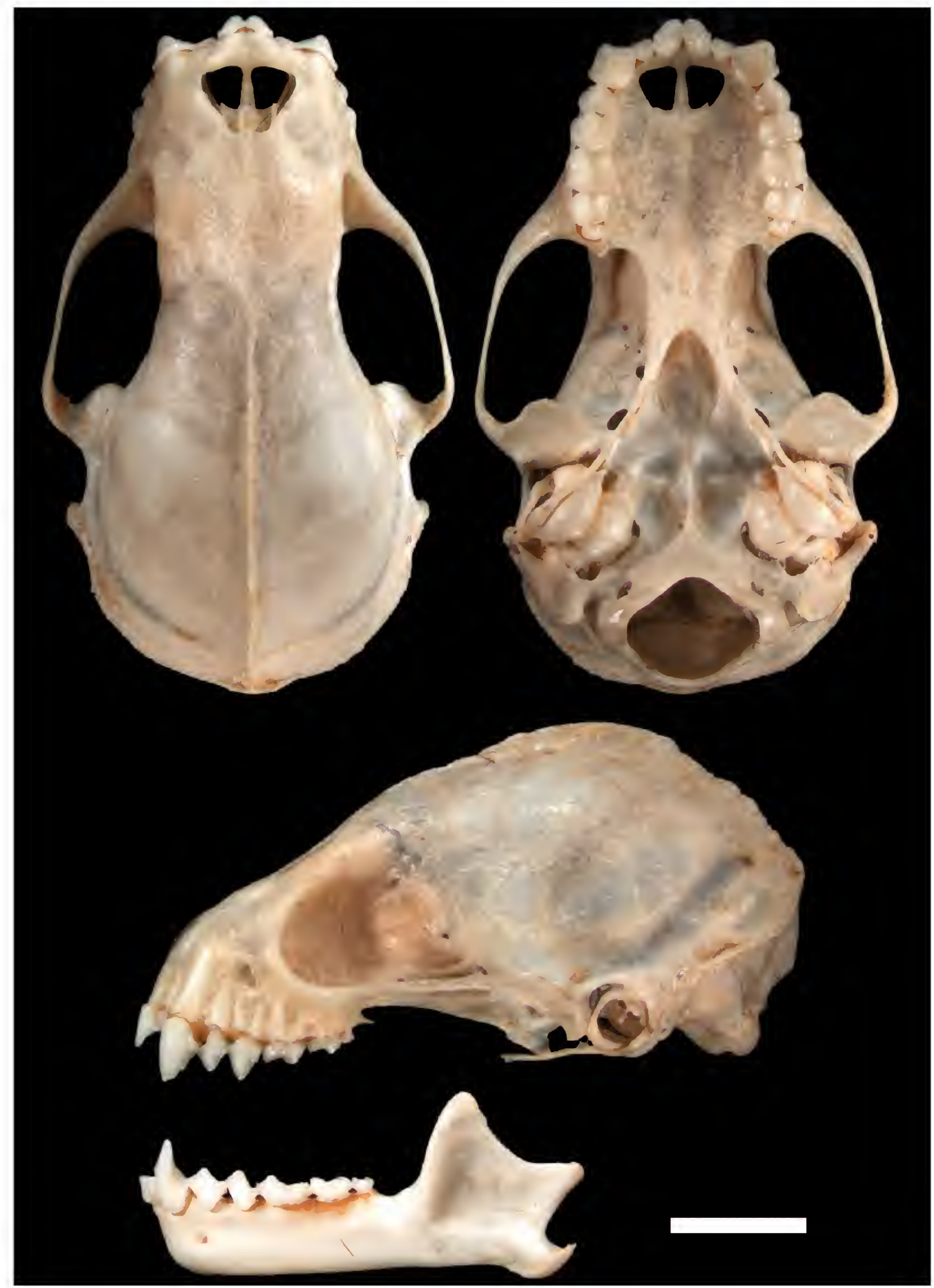

FIG. 2. Dorsal, ventral, and lateral views of the cranium and lateral view of the mandible of Sturnira giannae (AMNH 268545, holotype). Scale bar $=5 \mathrm{~mm}$. 


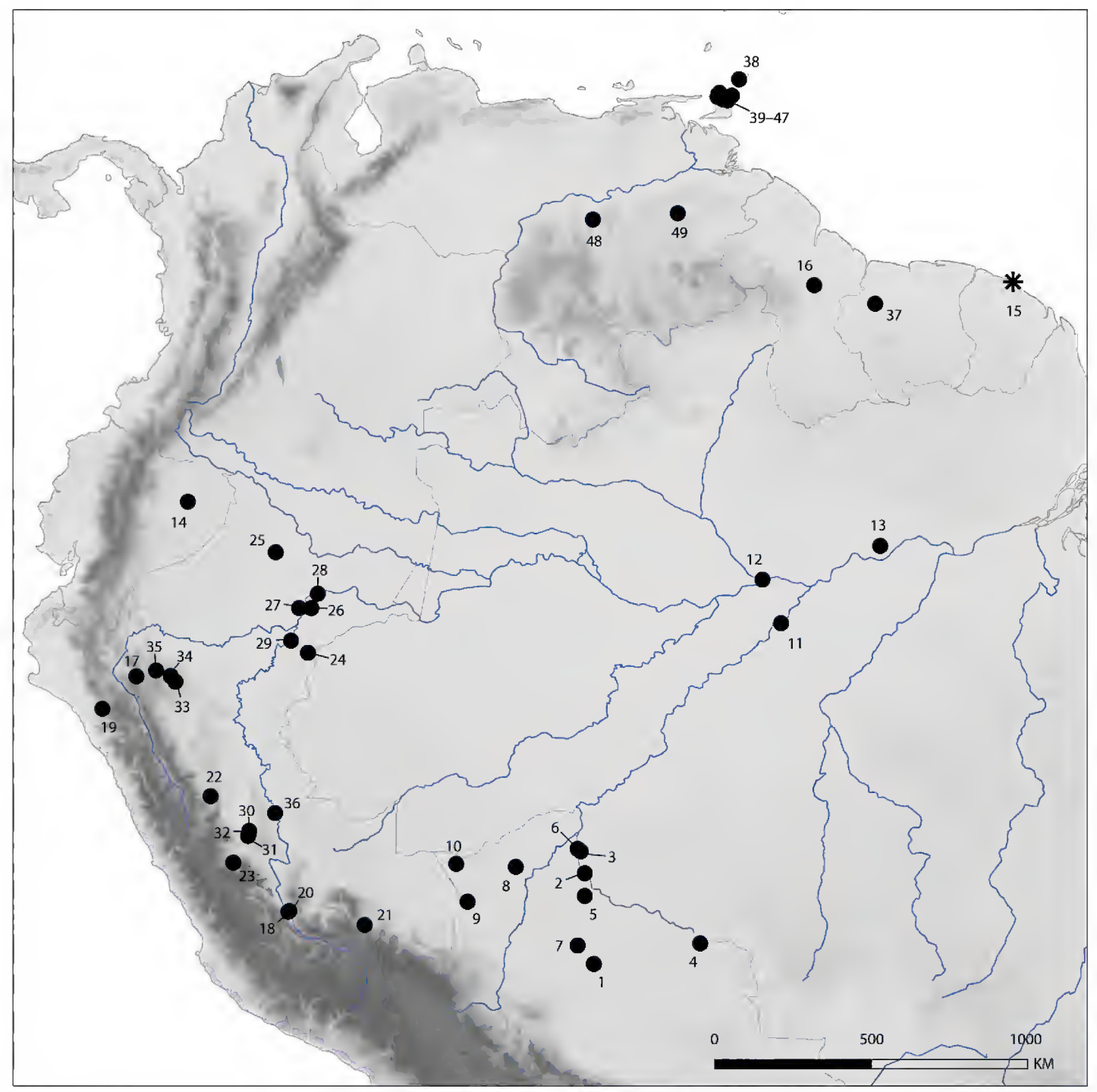

FIG. 3. Map showing selected collecting localities of Sturnira giannae as listed in the appendix. The type locality is marked by an asterisk. 


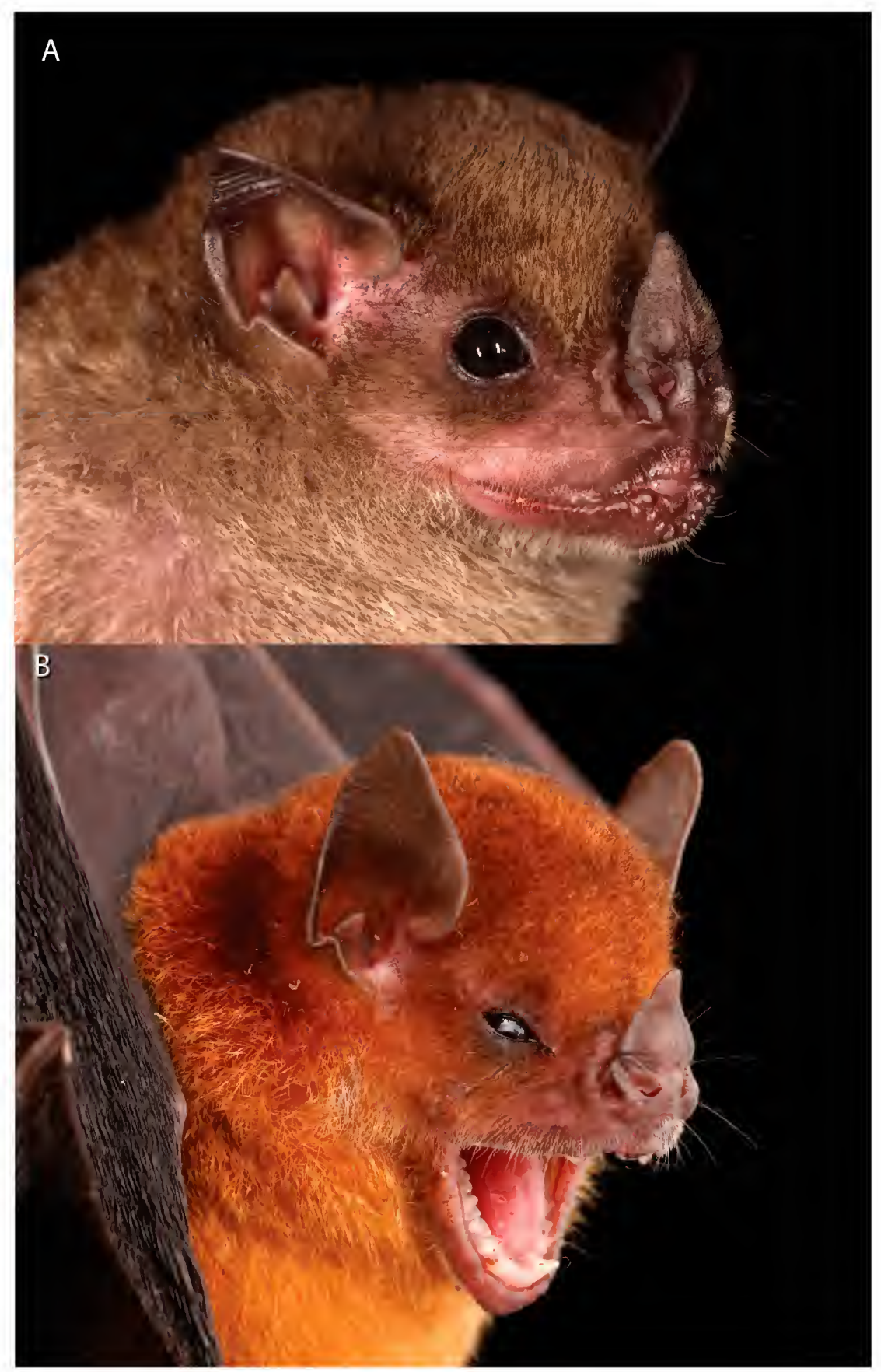

FIG. 4. Photographs of A, an adult male (ROM F63353) and B, an adult female (ROM 117574) Sturnira giannae captured at the Estación Biológica "José Álvarez Alonso," Reserva Nacional Allpahuayo-Mishana, Loreto, Peru, and Blanche Marie Vallen, Sipaliwini, Suriname, respectively. The two specimens illustrate the two extremes of the fur color variation in the species, with some specimens exhibiting brown fur (A) while others are much more reddish (B). Photographs by Marco Tschapka (A) and Alex Borisenko (B). 


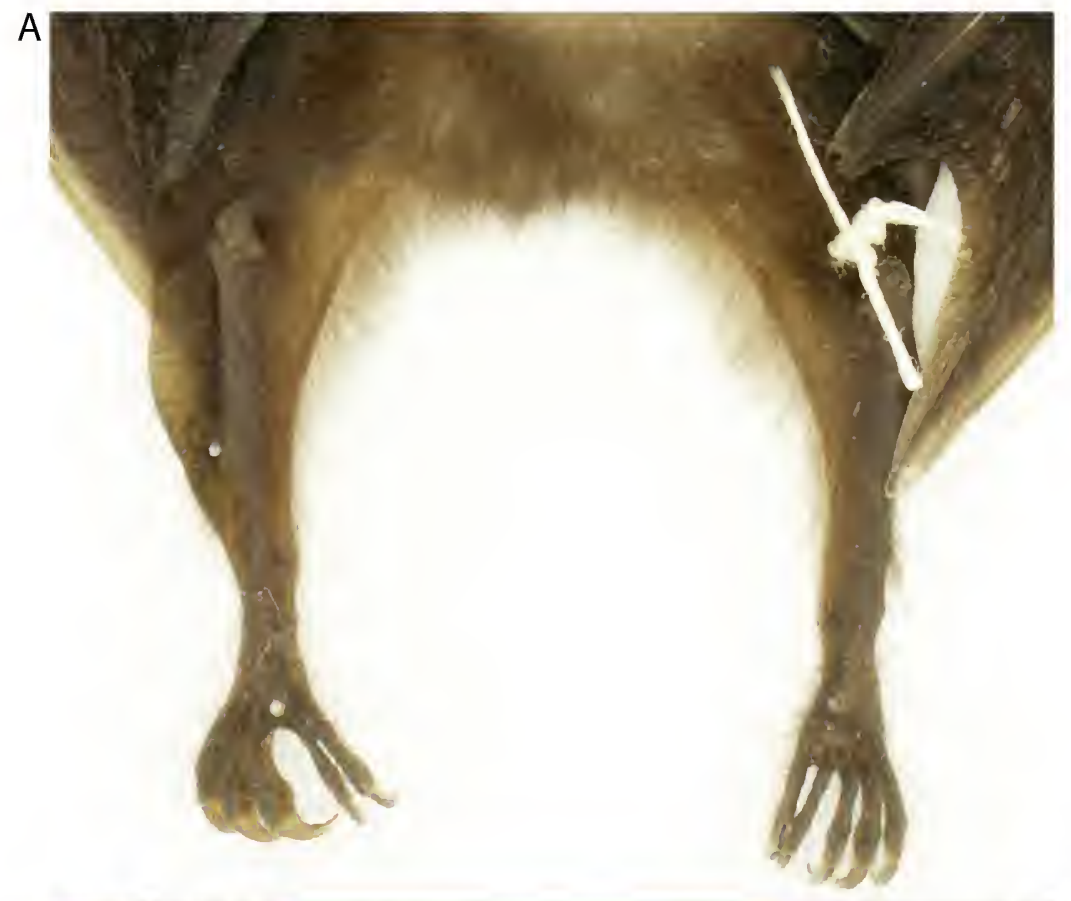

B

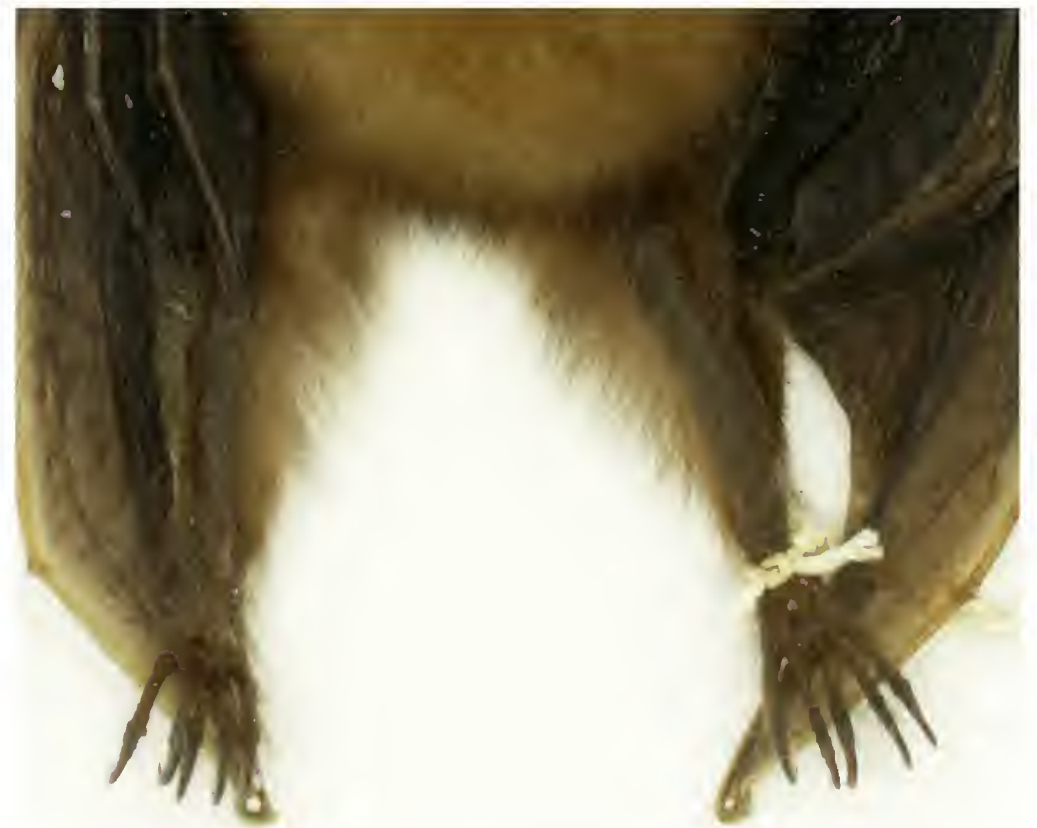

FIG. 5. Dorsal views of the uropatagium and legs in A, Sturnira giannae (FMNH 203590) and B, S. lilium (AMNH 205180) illustrating taxonomic differences in the degree of hairiness. In S. giannae, the trailing edge of the uropatagium is covered by short hairs $(4-6 \mathrm{~mm})$ and the dorsal surfaces of the tibia and feet are sparsely covered with long hairs. In S. lilium, the uropatagium is covered by long hairs $(7-9 \mathrm{~mm})$ and the tibia and feet are densely covered with long hairs. 
TABLE 15

External and craniodental measurements $(\mathrm{mm})$ and weights $(\mathrm{g})$ of Sturnira giannae and S. tildae

\begin{tabular}{|c|c|c|c|c|}
\hline & \multicolumn{2}{|c|}{ Sturnira giannae } & \multicolumn{2}{|c|}{ Sturnira tildae } \\
\hline & 15 males $^{\mathrm{a}}$ & 14 females $^{b}$ & 5 males $^{c}$ & 2 females $^{\mathrm{d}}$ \\
\hline W & $20.0(19.0-25.3) 9$ & $19.3(17.0-24.0) 13$ & $20.3(17.0-24.5) 5$ & $23.0,15.0$ \\
\hline TTL & $65.8(60.0-73.0) 11$ & $64.9(60.0-71.0) 14$ & $70.6(67.0-74.0) 5$ & $66.0,61.0$ \\
\hline $\mathrm{HF}$ & $12.8(11.0-15.0) 11$ & $12.7(11.0-14.0) 14$ & $12.6(11.0-14.0) 5$ & $15.0,14.0$ \\
\hline EL & $16.0(14.0-17.0) 11$ & $16.2(15.0-17.0) 14$ & $17.5(16.0-19.0) 5$ & $18.0,16.0$ \\
\hline FA & $44.8(43.0-47.0) 14$ & $43.8(41.0-45.0) 14$ & $45.8(45.0-47.0) 5$ & $46.0,45.0$ \\
\hline GLS & $22.8(22.1-24.2) 14$ & $22.2(21.7-22.9) 13$ & $22.6(22.2-23.4) 5$ & $22.4,22.1$ \\
\hline CIL & $21.2(20.7-21.8) 14$ & $20.8(20.1-21.3) 13$ & $21.5(21.2-21.8) 5$ & $21.2,20.9$ \\
\hline CCL & $20.4(20.0-21.0) 14$ & $20.0(19.3-20.6) 13$ & $20.8(20.4-21.2) 5$ & $20.4,20.2$ \\
\hline РOB & $6.0(5.8-6.4) 14$ & $5.8(5.4-6.2) 13$ & $6.0(5.7-6.3) 5$ & $6.2,6.0$ \\
\hline $\mathrm{ZB}$ & $14.1(13.5-15.2) 13$ & $13.5(13.0-13.9) 11$ & $13.7(13.5-14.2) 5$ & $13.9,13.0$ \\
\hline $\mathrm{BCB}$ & $10.4(10.1-10.9) 14$ & $10.2(9.8-11.0) 13$ & $10.3(10.1-10.5) 5$ & $10.4,10.2$ \\
\hline $\mathrm{MB}$ & $12.4(11.8-12.8) 14$ & $12.0(11.5-12.9) 13$ & $12.1(11.6-12.3) 5$ & $12.3,12.1$ \\
\hline MTR & $6.7(6.5-7.2) 14$ & $6.7(6.4-7.1) 13$ & $6.7(6.5-6.9) 5$ & 6.9 .6 .5 \\
\hline $\mathrm{BM}$ & $8.2(7.8-8.6) 14$ & $8.1(7.7-8.4) 14$ & $8.1(7.7-8.3) 5$ & $8.4,8.1$ \\
\hline DENL & $15.3(15.0-16.0) 8$ & $14.7(14.2-15.1) 8$ & $14.3(13.9-14.4) 4$ &,- 13.8 \\
\hline MANDL & $7.8(7.5-8.6) 8$ & $7.6(7.3-7.9) 8$ & $7.1(7.0-7.3) 4$ &,- 7.1 \\
\hline
\end{tabular}

a Summary statistics (mean, observed range in parentheses, and sample size) for measurements of AMNH 268545; FMNH 87058, 128825, 203412, 203416, 203586, 203590; MUSM 5925, 21266, 39225, 39226, 39228; ROM 103552, $105875,107936$. b Summary statistics (mean, observed range in parentheses, and sample size) for measurements of FMNH 203408, 203410, 203414, 203420, 203582, 203584, 203588; MUSM 5922, 5924, 13260, 39223, 39224, 39227, 39229.

c Summary statistics (mean, observed range in parentheses, and sample size) for measurements of FMNH 203592; MUSM 39231-39233, 39235.

d FMNH 203418; MUSM 39234.

39228). The trailing edge of the uropatagium is covered by short hairs $(5.0 \mathrm{~mm})$ (fig. $5 \mathrm{~A})$. The proximal portion of the forearm (roughly $50 \%$ of the shaft just distal to the elbow) is densely furred with short hairs. The dorsal surfaces of the tibia and feet are sparsely covered with long hairs. The III and IV metacarpals are subequal in length, but shorter than the V metacarpal.

The skull of Sturnira giannae has a globular braincase with a slender rostrum and well-developed sagittal crest (smaller in females but still well developed). Postorbital processes moderately developed (fig. 2). The posterior border of hard palate shows intraspecific variation, some individuals with a U-shaped border while in others it is V-shaped. The basisphenoid pits are divided by a narrow midline septum (fig. 2). The sphenorbital fissure is oval or circular, but always small. The zygomatic arches do not converge anteriorly. The anterior process of the glenoid fossa is well developed (fig. 2).

Sturnira giannae has a dental formula of $\mathrm{I} 2 / 2$, $\mathrm{C} 1 / 1, \mathrm{P} 2 / 2, \mathrm{M} 3 / 3=32$ teeth. The upper inner incisor (I1) is bicuspidate, with these cusps noticeable only in younger individuals without pronounced tooth wear (fig. 6A). The I1 is orthodont, slender, and at least twice the height of I2. P4 is shorter anteroposteriorly than $\mathrm{P} 5$, and the crown height of $\mathrm{P} 4$ is slightly less than that of P5. P5 has a small distal 
cusp. The anteroposterior and labiolingual lengths of M1 exceed those of M2. The protocones of P5, $\mathrm{M} 1$, and M2 are tall and well developed. The paracones of M1 and M2 are slightly shorter than corresponding metacones on the same teeth. The M3 is ovoid in shape and has one lingual and one or two labial cones (cusps). If two labial cones are present, they are divided by a shallow notch. The first and second lower incisors (i1 and i2) are tricuspidate and subequal in height. The lower canine covers less than $25 \%$ of the occlusal area of i2. The lower canine shafts are slightly oriented outward. The lower canine is less than $2 \times$ the height of $p 1$. The anteroposterior length of $\mathrm{p} 5$ exceeds that of $\mathrm{p} 1$. The $\mathrm{p} 1$ is slightly higher than $\mathrm{p} 5$. The protoconid, hypoconid, metaconid, and entoconid are present on $\mathrm{m} 1$ and $\mathrm{m} 2$. The paraconid is present and well developed on $\mathrm{m} 1$ but absent on $\mathrm{m} 2$. The lingual cuspids (metaconid and entoconid) on $\mathrm{m} 1$ and $\mathrm{m} 2$ are long anteroposteriorly. The metaconids and entoconids of $\mathrm{ml}$, $\mathrm{m} 2$, and $\mathrm{m} 3$ are well defined and separated by a deep notch (fig. 7A). In some individuals, the metaconids of $\mathrm{m} 2$ is divided into two cusps (e.g., MUSM 5922, 39228). The protoconid is the tallest cuspid on $\mathrm{m} 1$ and the entoconid is the lowest. All the four cuspids present on $\mathrm{m} 2$ are subequal in height. The $\mathrm{m} 3$ is small with only the protoconid, metaconid, and entoconid present. All three cuspids of $\mathrm{m} 3$ are subequal in height.

COMPARISONS: Sturnira giannae was compared with all the species of the lilium complex (S. angeli, S. bakeri, S. lilium, S. luisi, S. parvidens, and S. paulsoni) (Velazco and Patterson, 2013) and with other species of the genus that occur in sympatry with it (e.g., S. magna, S. oporaphilum, S. sorianoi, and S. tildae). External and craniodental measurements for S. giannae and the compared species are provided in tables 14-16 (S. lilium and S. tildae); other relevant sources of measurement data are de la Torre (1966: in text-S. angeli and S. magna), de la Torre and Schwartz (1966: in text-S. paulsoni), Jones and Phillips (1976: table 1-S. angeli and S. paulsoni), Molinari et al. (2017: table 3-S. oporaphilum), Sánchez-Hernández et al. (2005: table 2-S. sorianoi),
Simmons and Voss (1998: table 45-S. tildae), Tamsitt et al. (1986: table 1-S. magna), Velazco and Patterson (2014: tables 1-2-S. bakeri, S. luisi, S. oporaphilum, and $S$. parvidens), Kwiecinski et al. (2018: table 1-S. paulsoni paulsoni), and Pedersen et al. (2018: table 1--S. paulsoni luciae).

Size serves to distinguish some but not all Sturnira species. Sturnira giannae can be easily distinguished from S. magna by the latter's longer forearm and longer greatest length of skull (Tamsitt et al., 1986: table 1) and from S. parvidens by that bat's shorter forearm and shorter greatest length of skull (Velazco and Patterson, 2014: table 2). Sturnira giannae, S. angeli, S. bakeri, S. lilium, S. luisi, S. oporaphilum, S. paulsoni, S. sorianoi, and $S$. tildae overlap somewhat in size but are unambiguously distinguished by pelage and craniodental characteristics (tables 15-17).

Externally, the dorsal fur between the shoulders of $S$. giannae, S. luisi, and S. parvidens is short (4.0-6.0 mm) whereas it is long (>8 mm) in S. angeli, S. lilium, S. magna, S. sorianoi, S. oporaphilum, and S. tildae. Individual dorsal hairs are bicolored in $S$. giannae, S. lilium, S. luisi, and S. parvidens whereas they are 4-colored in S. angeli, S. magna, S. sorianoi, S. oporaphilum, and $S$. tildae. The overall appearance of the dorsal pelage is brown to reddish brown in S. giannae and S. tildae, whereas it is pale brown in S. angeli, S. lilium, S. luisi, S. magna, and S. oporaphilum, slightly reddish in $S$. parvidens, and pale gray in S. sorianoi. Ventrally the hairs are short (3-5 $\mathrm{mm}$ ) and monocolored in S. giannae and S. tildae, whereas they are long $(6-8 \mathrm{~mm})$ and monocolored in S. lilium, short (4.0-6.0 mm) and bicolored in $S$. luisi, short (3-5 mm) and tricolored in S. parvidens, long $(6-8 \mathrm{~mm})$ and tricolored in S. angeli, S. sorianoi, and $S$. oporaphilum, and short (3-5 $\mathrm{mm})$ and 4-colored in S. magna. The ventral fur is pale brown to reddish brown in S. giannae, whereas is pale brown in S. angeli, S. lilium, S. magna, S. sorianoi, S. oporaphilum, and S. tildae, dark gray in S. luisi, and reddish in S. parvidens. Shoulder glands (epaulettes) are weakly to strongly developed in specimens of $S$. giannae, whereas epaulettes are weakly defined in $S$. 


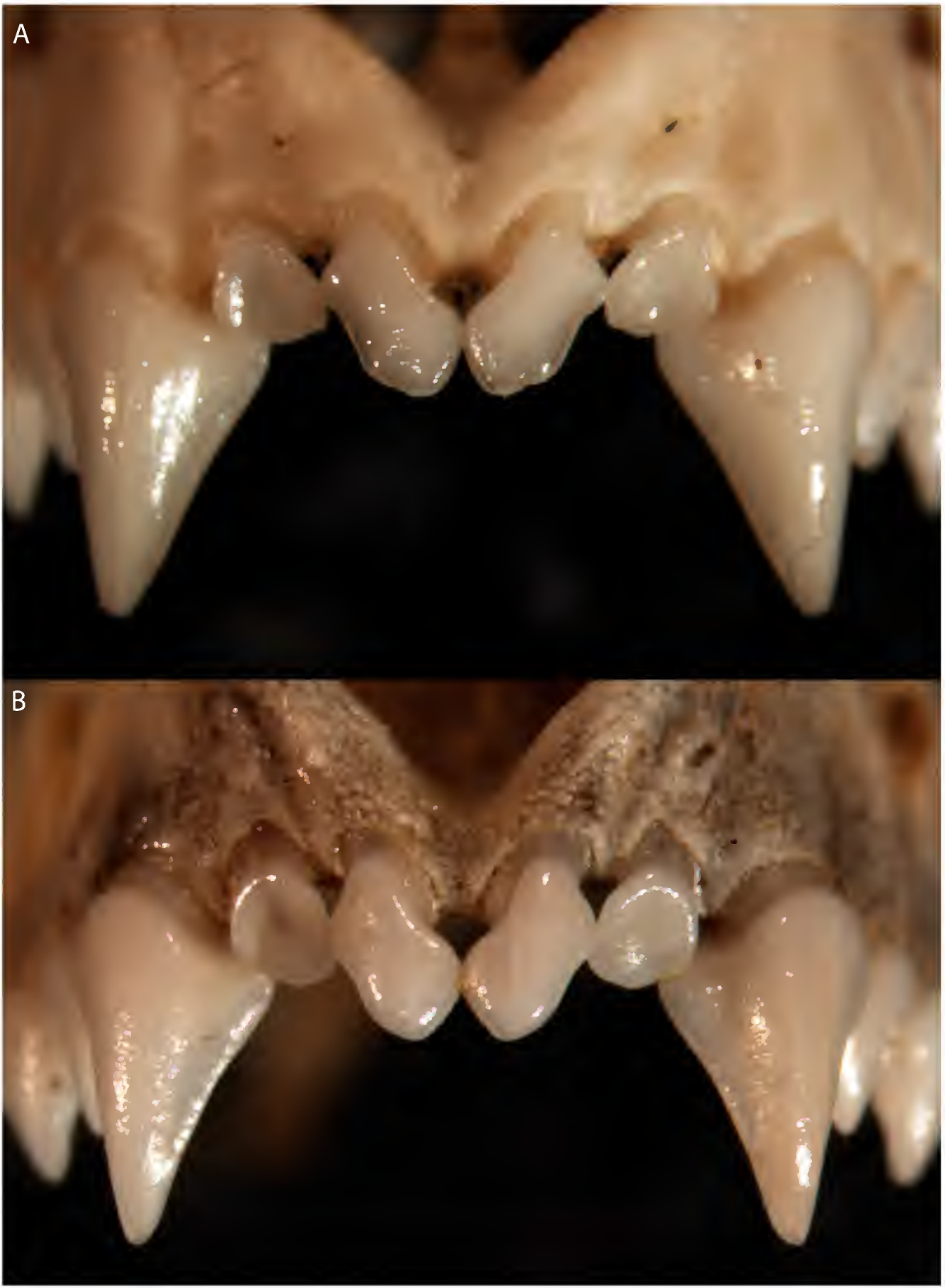

FIG. 6. Anterior views of the upper incisors and canines in A, Sturnira giannae (MUSM 13260) and B, S. lilium (AMNH 185320) illustrating taxonomic differences in the number of cuspids of the upper inner incisor (I1). In S. giannae the I1 is bicuspidate while in S. lilium I1 is unicuspidate. 


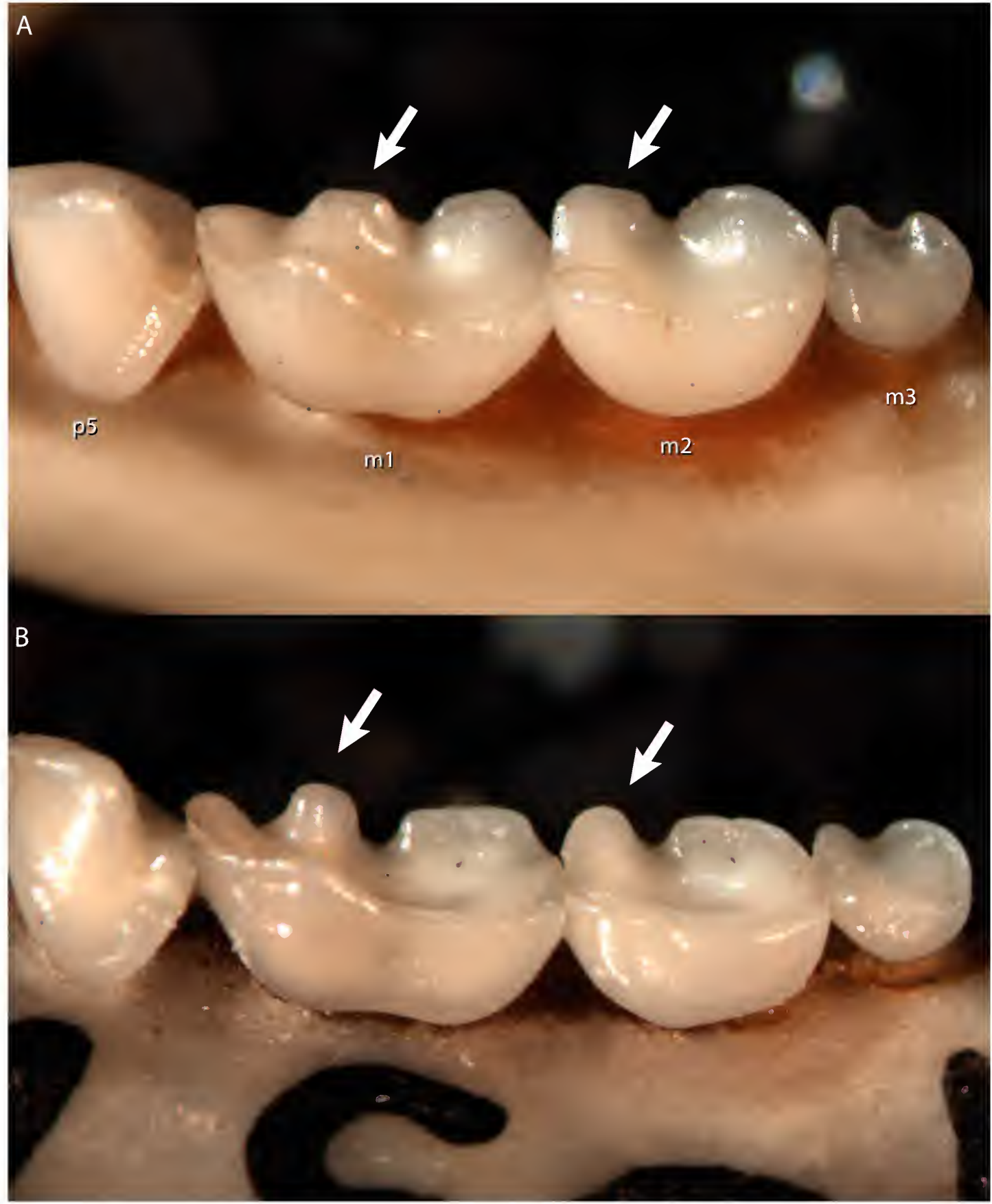

FIG. 7. Dorsolateral views of the left mandibular toothrows in A, Sturnira giannae (AMNH 268545) and B, S. lilium (AMNH 205180), illustrating taxonomic differences in the shape of the metaconids of $\mathrm{m} 1$ and $\mathrm{m} 2$. In $S$. giannae, the metaconids of $\mathrm{m} 1$ and $\mathrm{m} 2$ are longer mesiodistally (arrows). In $S$. lilium, however, the metaconids of $\mathrm{m} 1$ and $\mathrm{m} 2$ are shorter mesiodistally (arrows). 
sorianoi and S. oporaphilum and more conspicuous in S. angeli, S. lilium, S. luisi, S. magna, S. parvidens, and $S$. tildae. The trailing edge of the uropatagium is covered by short hairs $(4-6 \mathrm{~mm})$ in $S$. giannae, S. luisi, S. oporaphilum, S. parvidens, and S. tildae, whereas the uropatagium is covered by long hairs (7-9 mm) in S. angeli, S. lilium, S. magna, and S. sorianoi (fig. 5 ). The proximal portion of the forearm (roughly $50 \%$ of the shaft just proximal to the elbow) is densely furred with short hairs in $S$. giannae, S. angeli, S. parvidens, and S. tildae, whereas it is sparsely furred with short hairs in S. luisi and $S$. oporaphilum and sparsely furred with long hairs in $S$. lilium, S. magna, and S. sorianoi. The dorsal surfaces of the tibia and feet are sparsely covered with long hairs in S. giannae, S. angeli, S. magna, S. sorianoi, S. oporaphilum, and $S$. tildae, whereas the tibia and feet are densely covered with long hairs in S. lilium, the tibia is sparsely covered with long hairs and the feet are densely covered with long hairs in S. parvidens, and the tibia is sparsely covered with short hairs and the feet are densely covered with short hairs in S. luisi. Metacarpal IV is subequal to metacarpal III in S. giannae, S. angeli, S. lilium, S. luisi, S. magna, S. sorianoi, and S. oporaphilum, whereas metacarpal IV is shorter than metacarpal III in S. parvidens and longer than metacarpal III in S. tildae.

Cranially, the sagittal crest is well developed in S. giannae, S. lilium, S. magna, S. paulsoni, and S. tildae, whereas it is weakly developed in $S$. angeli, $S$. sorianoi, and S. oporaphilum. The postorbital processes are moderately developed in S. giannae, $S$. oporaphilum, S. paulsoni, and S. tildae, whereas they are well developed in $S$. angeli, S. magna, and $S$. sorianoi. The postorbital processes of S. lilium vary from moderately developed to well developed. The basisphenoid pits are divided by a narrow midline septum in S. giannae, S. lilium, S. luisi, S. magna, S. parvidens, and $S$. tildae, whereas the midline septum is broader in S. angeli, S. oporaphilum, S. paulsoni, and $S$. sorianoi. The sphenorbital fissure is small in S. giannae and S. magna, whereas it is large in $S$. angeli, S. lilium, S. oporaphilum, and S. sorianoi. Some specimens of $S$. tildae and S. paulsoni present a small sphenorbital fissure whereas in others it is large. The zygomatic arches do not converge anteriorly in S. giannae, S. lilium, S. magna, S. oporaphilum, S. sorianoi, and S. tildae, whereas they are bowed outward in S. angeli, S. luisi, S. paulsoni, and $S$. parvidens. The anterior process of the glenoid fossa is well developed in S. giannae, S. magna, $S$. luisi, and $S$. parvidens, whereas it is weakly developed in S. paulsoni, S. sorianoi, and S. tildae, and absent in S. angeli. Some specimens of S. lilium and S. oporaphilum lack the anterior process of the glenoid fossa while in others it is weakly developed.

Dentally, I1 is bicuspidate in S. giannae, $S$. angeli, S. luisi, S. magna, S. parvidens, S. sorianoi, and $S$. tildae, whereas it is unicuspidate in S. lilium, S. oporaphilum, and S. paulsoni (fig. 6). The I1 is orthodont and slender in S. giannae, S. angeli, $S$. lilium, and S. paulsoni, whereas this tooth is orthodont and broad in S. oporaphilum, S. sorianoi, and S. tildae, and proodont and broad in S. magna. The protocones of P5, M1, and M2 are tall and well developed in S. giannae, S. oporaphilum, and $S$. sorianoi, whereas they are low and weakly developed in S. angeli and S. magna. These protocones are well developed in some specimens of S. lilium (AMNH 185320), whereas in others they are low and weakly developed (AMNH 205180, 256984). In Sturnira paulsoni and S. tildae, the protocones of M1 and M2 are tall and well developed but on P5, the protocone is low and weakly developed. The i1 and i2 are tricuspidate in S. giannae, S. angeli, S. lilium, S. luisi, S. magna, S. paulsoni, S. parvidens, S. sorianoi, and $S$. tildae, whereas they are bicuspidate in S. oporaphilum. The metaconids and entoconids of $\mathrm{m} 1$ and $\mathrm{m} 2$ are well defined and separated by a deep notch in $S$. giannae, S. lilium, S. luisi, S. paulsoni, and S. parvidens, whereas they are well defined but separated by a shallow notch in $S$. angeli and $S$. tildae, and poorly defined and not separated by a notch in S. magna, S. oporaphilum, and S. sorianoi. The metaconids of $\mathrm{m} 1$ and $\mathrm{m} 2$ are well defined and long mesiodistally in S. giannae and S. angeli, whereas they are well defined and short mesiodistally in $S$. lilium, S. tildae, and S. paulsoni, and poorly defined 
TABLE 16

External and craniodental measurements $(\mathrm{mm})$ and weights $(\mathrm{g})$ of Sturnira lilium

\begin{tabular}{lcc}
\hline & \multicolumn{2}{c}{ Sturnira lilium } \\
\cline { 2 - 3 } W & $21.5(19.0-28) 4$ & 4 females $^{\mathrm{a}}$ \\
TTL & $65.9(55.0-70.0) 11$ & $65.3(60.0-69.0) 4$ \\
HF & $13.7(11.0-16.0) 11$ & $14.8(12.0-17.0) 4$ \\
EL & $17.3(14.0-20.0) 10$ & $16.7(15.0-18.0) 3$ \\
FA & $42.3(39.8-44.9) 11$ & $41.7(40.6-43.4) 4$ \\
GLS & $22.5(21.2-22.9) 11$ & $22.1(21.7-22.9) 4$ \\
CIL & $20.8(20.0-21.4) 11$ & $20.4(20.0-20.9) 4$ \\
CCL & $20.1(19.4-20.7) 11$ & $19.6(19.3-20.0) 4$ \\
POB & $6.1(5.5-6.4) 11$ & $5.9(5.7-6.1) 4$ \\
ZB & $14.1(13.6-14.5) 9$ & $13.4(13.1-13.8) 4$ \\
BCB & $10.5(10.1-10.7) 11$ & $10.3(10.1-10.6) 4$ \\
MB & $12.3(11.8-12.8) 11$ & $11.8(11.2-12.3) 4$ \\
MTR & $6.9(6.7-7.1) 10$ & $6.6(6.5-6.7) 4$ \\
BM & $8.3(8.0-8.7) 10$ & $8.0(7.8-8.1) 4$ \\
DENL & $15.0(14.2-15.5) 11$ & $14.6(14.2-15.0) 4$ \\
MANDL & $7.9(7.5-8.2) 11$ & $7.4(7.4-7.6) 4$ \\
\hline
\end{tabular}

a Summary statistics (mean, observed range in parentheses, and sample size) for measurements of AMNH 23802, 23803, 185321, $186949,205178,205179,205181,217542,234280,256984,268400$.

b Summary statistics (mean, observed range in parentheses, and sample size) for measurements of AMNH 185320, 205177, 205180, 217541.

in S. magna, S. oporaphilum, and S. sorianoi (fig. 7). The metaconid and entoconid of $\mathrm{m} 3$ are separated by a deep notch in S. giannae, S. lilium, and S. paulsoni (when $\mathrm{m} 3$ is present), whereas these cusps are separated by a weak notch in S. angeli and S. magna and not separated in S. oporaphilum (fig. 7). Some specimens of $S$. sorianoi and $S$. tildae present the metaconid and entoconid of $\mathrm{m} 3$ separated by a weak notch while in others they are not separated.

NATURAL History: Natural history information on $S$. giannae has been previously reported under the name Sturnira lilium, where it is mixed with reports from S. angeli, S. lilium sensu stricto, S. parvidens, and S. paulsoni. We discriminate the information of $S$. giannae from published records of S. angeli, S. lilium sensu stricto, S. parvidens, and S. paulsoni, all previously considered subspecies of
S. lilium sensu lato (Velazco and Patterson, 2013), by considering only reports from the lower Orinoco and the Amazon basins as belonging to $S$. giannae. This species may occur in a wide variety of forested habitats, excluding only very dry forests and those above $2000 \mathrm{~m}$ elevation (Handley, 1976). Its documented roosting sites include dense foliage, tree holes, caves, and culverts (Linares, 1998) as well as buildings (Goodwin and Greenhall, 1961). S. giannae is a frugivorous bat that has been reported to feed on at least 41 plant species representing 20 genera in 14 families: Cyathula prostrata (Amaranthaceae); Rollinia exsucca (Annonaceae); Couma utilis (Apocynaceae); Anthurium trinerve, Philodendron grandifolium, Ph. squamiferum, Ph. sp. (Araceae); Carica papaya, Jacaratia digitata (Caricaceae); Cecropia distachya, Ce. ficifolia, Ce. 
TABLE 17

Morphological differences among Sturnira giannae, S. lilium, S. oporaphilum, and S. tildae

\begin{tabular}{|c|c|c|c|c|}
\hline Character & S. giannae & S. lilium & S. oporaphilum & S. tildae \\
\hline Dorsal fur length & Short & Long & Long & Long \\
\hline Dorsal fur bands & Bicolored & Bicolored & Tetracolored & Tetracolored \\
\hline Ventral fur length & Short & Long & Long & Short \\
\hline Ventral fur bands & Monocolored & Monocolored & Tricolored & Monocolored \\
\hline $\begin{array}{l}\text { Hairs on the trailing } \\
\text { edge of the uropatagium }\end{array}$ & Short & Long & Short & Short \\
\hline $\begin{array}{l}\text { Proximal portion of the } \\
\text { forearm }\end{array}$ & $\begin{array}{l}\text { Densely furred } \\
\text { with short hairs }\end{array}$ & $\begin{array}{l}\text { Sparsely furred with } \\
\text { long hairs }\end{array}$ & $\begin{array}{l}\text { Sparsely furred with } \\
\text { short hairs }\end{array}$ & $\begin{array}{l}\text { Densely furred with } \\
\text { short hairs }\end{array}$ \\
\hline $\begin{array}{l}\text { Dorsal surfaces of the } \\
\text { tibia and feet }\end{array}$ & $\begin{array}{l}\text { Sparsely covered } \\
\text { with long hairs }\end{array}$ & $\begin{array}{l}\text { Densely covered } \\
\text { with long hairs }\end{array}$ & $\begin{array}{l}\text { Sparsely covered with } \\
\text { long hairs }\end{array}$ & $\begin{array}{l}\text { Sparsely covered with } \\
\text { long hairs }\end{array}$ \\
\hline Metacarpal III and IV & Met III = IV & Met III = IV & Met III = IV & Met III < IV \\
\hline Sagittal crest & Well developed & Well developed & Weakly developed & Well developed \\
\hline Sphenorbital fissure & Small & Large & Large & Small or large \\
\hline $\begin{array}{l}\text { Anterior process of the } \\
\text { glenoid fossa }\end{array}$ & Well developed & $\begin{array}{l}\text { Weakly developed or } \\
\text { absent }\end{array}$ & $\begin{array}{l}\text { Weakly developed or } \\
\text { absent }\end{array}$ & Weakly developed \\
\hline Upper inner incisors & $\begin{array}{l}\text { Bicuspidate and } \\
\text { slender }\end{array}$ & $\begin{array}{l}\text { Unicuspidate and } \\
\text { slender }\end{array}$ & $\begin{array}{l}\text { Unicuspidate and } \\
\text { broad }\end{array}$ & Bicuspidate and broad \\
\hline Lower incisors & Tricuspidate & Tricuspidate & bicuspidate & Tricuspidate \\
\hline $\begin{array}{l}\text { Metaconids and entoco- } \\
\text { nids of } \mathrm{m} 1 \text { and } \mathrm{m} 2\end{array}$ & $\begin{array}{l}\text { Well defined and } \\
\text { separated by a } \\
\text { deep notch }\end{array}$ & $\begin{array}{l}\text { Well defined and } \\
\text { separated by a deep } \\
\text { notch }\end{array}$ & $\begin{array}{l}\text { Poorly defined and are } \\
\text { not separated by a } \\
\text { notch }\end{array}$ & $\begin{array}{l}\text { Well defined but sepa- } \\
\text { rated by a shallow } \\
\text { notch }\end{array}$ \\
\hline $\begin{array}{l}\text { Metaconids of } \mathrm{m} 1 \text { and } \\
\mathrm{m} 2\end{array}$ & $\begin{array}{l}\text { Well defined and } \\
\text { broad mesiodis- } \\
\text { tally }\end{array}$ & $\begin{array}{l}\text { Well defined and } \\
\text { slender mesiodistally }\end{array}$ & Poorly defined & $\begin{array}{l}\text { Well defined and slen- } \\
\text { der mesiodistally }\end{array}$ \\
\hline $\begin{array}{l}\text { Metaconid and entoco- } \\
\text { nid of } \mathrm{m} 3\end{array}$ & $\begin{array}{l}\text { Separated by a } \\
\text { deep notch }\end{array}$ & $\begin{array}{l}\text { Separated by a deep } \\
\text { notch }\end{array}$ & Not separated & $\begin{array}{l}\text { Separated by a weak } \\
\text { notch or not separated }\end{array}$ \\
\hline
\end{tabular}

obtusa (Cecropiaceae); Clusia sp., Vismia guianensis, Vismia sp. (Clusiaceae); Muntingia calabura (Elaeocarpaceae); Banara guianensis (Flacourtiaceae); Poraqueiba sericea (Icacinaceae); Byrsonima sp. (Malpiguiaceae); Ficus panurensis, F. paraensis (Moraceae); Piper aduncum, Pi. bartlingianum, Pi. hostmannianum; Pi. sp. (Piperaceae); Coffea sp. (Rubiaceae); Markea longiflora, Solanum asperum, So. caavurana, So. confine, So. coriaceum, So. grandiflorum, So. lanceolatum, So. leucocarpon, So. paniculatum, So. rugosum, So. schlechtendalianum, So. subinerme, So. torvum, So. sp. (Solanaceae); Celtis schippii (Ulmaceae) (dos Reis and Guillaumet, 1983; de Foresta et al., 1984; Charles-Dominique, 1986, 1993; Foster et al., 1986; dos Reis and Peracchi, 1987; Maas et al., 1992; Gorchov et al., 1995; Charles-Dominique and Cockle, 2001; Lobova et al., 2003, 2009; Lobova and Mori, 2004).

Lactating females have been reported in the months of May, June, and November in Peru (Hice 
et al., 2004) and pregnant females in the months of March, July, August, October, and November in Peru (Tuttle, 1970; Hice et al., 2004) and in June, July, and August in French Guiana (Brosset and Dubost, 1967). Both pregnant and lactating females were reported in December and January in Pará and Amazonas, Brazil (Marques-Aguiar, 1985).

Wenzel (1976) reported three species of streblid flies occurring on Sturnira giannae in Venezuela (Aspidoptera falcata, Trichobius lionycteridis, and Trichobius parasparsus). The dermatophytic fungi Exophiala (Wangiella) dermatitidis was isolated from the lung of one individual collected in a secondary forest in Manaus, Brazil (Reiss and Mok, 1979). The bacteria Bartonella and Leptospira were found in the single individual tested and in three of 38 individuals tested, respectively (Matthias et al., 2005; Bai et al., 2012). One of 43 Sturnira giannae near the type locality tested positive for rabies virus (de Thoisy et al., 2016).

Remarks: The synonymy of Sturnira lilium sensu lato includes several junior synonyms, one nomen nudum, and unavailable names. The majority of those are undoubtedly assignable to S. lilium sensu stricto (e.g., Phyllostoma spiculatum Lichtenstein, 1823; Phyllostoma excisum Wagner, 1842; Phyllostoma albescens Wagner, 1847; Phyllostoma chrysosema Natterer, 1883, in Pelzeln, 1883).

A specific type locality was not mentioned in the original description of five junior synonyms of Sturnira lilium. Phyllostoma vampyrus was described by Schinz (1845) from "America tropicali," but to our knowledge a holotype was not designated. The holotype of Nyctiplanus rotundatus, which was described by Gray (1849) with only "Brazils" as the type locality, is now lost (Carter and Dolan, 1978). Phyllostoma fumarium Wagner, 1847 was described based on a single specimen. Its label was lost while the specimen was being prepared as a study skin (with partial skull inside) and had been removed from its original fluid condition. Wagner (1847) remembered that the specimen was from Brazil but did not recall a specific locality within Brazil. Photographs of the holotype
(ZSM 58) clearly show that the trailing edge of the uropatagium and the tibia and feet are densely covered by long hairs characteristic of S. lilium. For that reason, we recommend continued assignment of Phyllostoma fumarium Wagner, 1847, as a junior synonym of Sturnira lilium (Geoffoy St.Hilaire, 1810). Sturnira spectrum Gray, 1842, was also described based on a specimen from Brazil. The label does not specify sex or a specific locality. Photographs of the holotype (BMNH 42.12.2.4), a dry study skin with a partial skull (only the rostrum is preserved) revealed two diagnostic characteristics of S. lilium: the trailing edge of the uropatagium and the tibia and feet are densely covered by long hairs and the inner upper incisors are unicuspidate. Therefore, we recommend that Sturnira spectrum Gray, 1842, should likewise be regarded as a junior synonym of Sturnira lilium (Geoffoy St.-Hilaire, 1810). The name Phyllostoma chrysocomos Wagner, 1855 should also be assigned to Sturnira lilium (Geoffoy St.-Hilaire, 1810) as a junior synonym because it is a renaming of Sturnira spectrum Gray, 1842.

\section{Sturnira oporaphilum (Tschudi, 1844)}

Voucher Material: Waqanki: 1 adult male (MUSM 39230); see table 13 for measurements.

IDENTIFICATION: We consulted descriptions and measurements of Sturnira oporaphilum provided by Carter and Dolan (1978), Anderson (1997), Velazco and Patterson (2014), and Molinari et al. (2017). No subspecies are currently recognized in S. oporaphilum (Velazco and Patterson, 2014; Molinari et al., 2017). Our specimen exhibits the diagnostic characteristics of $S$. oporaphilum: medium size (FA 42-47 mm); shoulder glands (epaulettes) present but weakly defined; metacarpals III and IV subequal in length, but shorter than metacarpal V; upper inner incisors orthodont; lower incisors bicuspidate; and metaconids and entoconids of $\mathrm{m} 1$ and $\mathrm{m} 2$ poorly defined, forming a continuous sloping ridge (Gardner, 2008e). Measurements of our speci- 
mens fall within the range of measurements previously reported for the species.

\section{Sturnira tildae de la Torre, 1959}

Voucher Material: Tingana: 1 adult male (MUSM 39235); Waqanki: 2 adult females (FMNH 203418; MUSM 39234), 4 adult males (FMNH 203592; MUSM 39231-39233); see table 15 for measurements.

IDENTIFICATION: We consulted descriptions and measurements of Sturnira tildae provided by de la Torre (1959), Goodwin and Greenhall (1961), Hill (1964), Marinkelle and Cadena (1971), Husson (1978), Genoways and Williams (1979), Swanepoel and Genoways (1979), Brosset and Charles-Dominique (1990), Anderson (1997), Simmons and Voss (1998), and Lim et al. (2005). No subspecies are currently recognized in S. tildae (Gardner, 2008e). Our specimens conform in all respects to previous descriptions of $S$. tildae and exhibit the diagnostic characteristics of the species: medium size (FA 43-51 $\mathrm{mm}$, GLS 24-26 mm); shoulder glands (epaulettes) present and well defined; metacarpal III shorter than metacarpal V; tips of inner upper incisors broad and weakly bicuspidate with lobes of equal size; metaconids and entoconids of $\mathrm{m} 1, \mathrm{~m} 2$, and $\mathrm{m} 3$ well defined and separated by a notch; and paraconulids not present on $\mathrm{m} 1$ and $\mathrm{m} 2$ (Gardner, 2008e). Measurements of our specimens fall within the range of measurements previously reported for the species.

\section{Key to the Species of Sturnira That Occur in Sympatry with $S$. giannae (modified from Gardner, 2008e)}

1. Lingual cuspids (metaconid and entoconid) of $\mathrm{m} 1$ and $\mathrm{m} 2$ poorly defined, usually forming a continuous sloping ridge. . .2

$1^{\prime}$. Lingual cuspids (metaconid and entoconid) of $\mathrm{m} 1$ and $\mathrm{m} 2$ well defined and separated by a notch.

2. Forearm longer than $51 \mathrm{~mm}$; greatest length of skull more than $27 \mathrm{~mm}$...Sturnira magna $2^{\prime}$. Forearm shorter than $50 \mathrm{~mm}$; greatest length of skull less than $27 \mathrm{~mm}$....................3

3. Forearm 41-44 mm; upper inner incisor bicuspidate; lower incisors tricuspidate. Sturnira sorianoi

3'. Forearm 42-47 mm; upper inner incisor; lower incisors bicuspidate

Sturnira oporaphilum

4. Forearm 43-51 mm; greatest length of skull 22-26 mm; tips of inner upper incisors broad and weakly bicuspidate; metaconid and entoconid of $\mathrm{m} 1$ and $\mathrm{m} 2$ separated by a shallow notch; dorsal fur 4-colored

Sturnira tildae

$4^{\prime}$. Forearm 41-48 mm; greatest length of skull 21-25 mm; tips of inner upper incisors slender and weakly bicuspidate; metaconid and entoconid of $\mathrm{m} 1$ and $\mathrm{m} 2$ separated by a deep notch; dorsal fur bicolored..Sturnira giannae

\section{Uroderma bilobatum Peters, 1866}

Voucher Material: Tingana: 4 adult females (FMNH 203460; MUSM 39238, 39240, 39241), 6 adult males (FMNH 203456, 203458, 203462, 203640; MUSM 39237, 39239); Waqanki: 1 adult female (MUSM 39236); see table 18 for measurements.

IDENTIFICATION: The latest taxonomic review of the Uroderma bilobatum species complex was by Mantilla-Meluk (2014). He recognized four species in this complex: the nominate species $U$. bilobatum, a newly described taxon (U. bakeri), and two species formerly treated as subspecies ( $U$. convexum and $U$. davisi). Currently, Uroderma bilobatum is thought to be restricted to east of the Andes (Mantilla-Meluk, 2014), and it can be distinguished from the other species of the genus by the following combination of characteristics: dark color, prominent facial stripes, yellowish ear margin (becoming pale yellow to white on dry museum skins), dorsum of uropatagium nearly naked, rostrum not elevated with a dorsal convexity present dorsally, interorbital constriction not swollen, junction of the nasal and maxillae forms 
TABLE 18

External and craniodental measurements $(\mathrm{mm})$ and weights $(\mathrm{g})$ of Uroderma bilobatum, Vampyressa thyone, and Thyroptera tricolor

\begin{tabular}{|c|c|c|c|c|}
\hline & \multicolumn{2}{|c|}{ Uroderma bilobatum } & \multirow{2}{*}{$\frac{\text { Vampyressa thyone }}{2 \text { males }^{\mathrm{a}}}$} & \multirow{2}{*}{$\begin{array}{l}\text { Thyroptera tricolor } \\
\text { FMNH } 203644 \text { ㅇ }\end{array}$} \\
\hline & 6 males & 5 females & & \\
\hline W & $17.3(15.5-19.0) 6$ & $18.5(14.4-22.0) 5$ & $8.0,7.0$ & 4.0 \\
\hline TTL & $65.3(62.0-68.0) 6$ & $66.2(64.0-71.0) 5$ & $54.0,47.0$ & 74.0 \\
\hline TL & -- & -- &,-- & 28.0 \\
\hline $\mathrm{HF}$ & $12.0(10.0-14.0) 6$ & $11.2(10.0-13.0) 5$ & $8.0,10.0$ & 5.0 \\
\hline EL & $17.8(16.0-18.5) 6$ & $17.5(15.0-19.0) 5$ & $13.0,14.5$ & 11.0 \\
\hline FA & $44.8(42.0-47.0) 6$ & $44.4(42.5-45.5) 5$ & $32.0,32.0$ & 37.0 \\
\hline GLS & $23.7(22.7-24.1) 6$ & $23.5(22.7-24.3) 5$ & $18.4,17.5$ & 13.3 \\
\hline CIL & $21.9(21.4-22.4) 6$ & $21.7(20.7-22.4) 5$ & $17.3,16.3$ & 13.3 \\
\hline CCL & $21.3(20.8-21.7) 6$ & $21.1(20.3-21.8) 5$ & $16.7,15.8$ & -- \\
\hline LB & $6.1(5.7-6.4) 6$ & $6.1(5.8-6.5) 5$ & $5.0,5.0$ & -- \\
\hline POB & $5.4(5.1-5.8) 6$ & $5.5(5.2-5.7) 5$ & $4.9,4.6$ & 2.7 \\
\hline $\mathrm{ZB}$ & $13.4(12.8-13.7) 6$ & $13.5(12.4-14.2) 5$ & $11.0,10.5$ & 7.5 \\
\hline $\mathrm{BCB}$ & $9.9(9.6-10.1) 6$ & $9.7(9.4-10.1) 5$ & $8.4,8.3$ & 7.4 \\
\hline $\mathrm{MB}$ & $11.4(11.0-11.7) 6$ & $11.2(10.8-11.4) 5$ & $9.2,9.1$ & 7.0 \\
\hline MTR & $8.4(8.2-8.5) 6$ & $8.4(8.2-8.5) 5$ & $6.2,5.8$ & 5.6 \\
\hline BM & $9.3(9.0-9.5) 6$ & $9.6(8.8-10.0) 5$ & $7.8,7.9$ & 5.4 \\
\hline $\mathrm{BC}$ & $5.8(5.5-6.0) 6$ & $5.8(5.5-6.0) 5$ & $4.4,4.5$ & 3.1 \\
\hline
\end{tabular}

${ }^{\text {a }}$ FMNH 203642; MUSM 39242.

an obtuse angle in lateral view, and the edge of the maxillae (that forms the eye socket) forms a rim. Additional measurements were provided by Goodwin and Greenhall (1961), Husson (1962, 1978), Davis (1968), Carter and Dolan (1978), Swanepoel and Genoways (1979), Brosset and Charles-Dominique (1990), Anderson (1997), Simmons and Voss (1998), and Lim et al. (2005). Three subspecies are recognized: $U . b$. bilobatum (lowlands east of the Andes in Venezuela, Colombia, Ecuador, Peru and Bolivia, east through the Guianas, and south to Brazilian Amazonia and eastern Brazil), $U$. b. thomasi (eastern piedmonts of the Andes in Ecuador, Peru, and Bolivia), and U. b. trinitatum (Trinidad). Based on distribution and range of measurements, our Mayo River basin voucher material should correspond to $U . b$. thomasi.

REMARKs: One female (MUSM 39236) that we collected was lactating.

Vampyressa thyone (Thomas, 1909)

Voucher Material: El Diamante: 2 adult males (FMNH 203642; MUSM 39242); see table 18 for measurements.

IDENTIFICATION: We consulted descriptions and measurements of Vampyressa thyone provided by Goodwin (1963), Ceballos Bendezú (1968), Anderson (1997), Lim et al. (2003), and Tavares et al. (2014). No subspecies are currently recognized 
in $V$. thyone (Arroyo-Cabrales, 2008b). Our Mayo River basin specimens exhibit the diagnostic characteristics of the species: small size (FA $<34 \mathrm{~mm}$; GLS $<19 \mathrm{~mm}$ ); facial stripes weak and dorsal stripe lacking; uropatagium narrow and sparsely haired; rostrum shorter than braincase; hard palate extends well behind the molars; upper inner incisors long, separated basally and converging at the bifid tips; first upper premolar smaller than the second; first lower premolar caniniform and smaller than the second premolar (ArroyoCabrales, 2008b). Measurements of our specimens fall within the range of measurements reported for the species.

\section{Family Thyropteridae Miller, 1907}

The Neotropical family Thyropteridae includes five species characterized by small size, the presence of a circular disk on the sole of each foot, and an oval or circular disk attached by a short pedicle to the base of each thumb (Velazco et al., 2014). One species was recorded at one locality.

\section{Thyroptera tricolor Spix, 1823}

Voucher Material: Tingana: 1 adult female (FMNH 203644); see table 18 for measurements.

IDENTIFICATION: We consulted descriptions and measurements of Thyroptera tricolor provided by Wilson and Findley (1977), Pine (1993), Solari et al. (2004), Bezerra et al. (2005), Lim et al. (2005), Gregorin et al. (2006), and Velazco et al. (2014). Three subspecies are currently recognized in $T$. tricolor: T. t. albiventer (southern Mexico southward to lowland Colombia and Ecuador), T. t. juquiaensis (known only from the type locality in the state of São Paulo, Brazil), and T. t. tricolor (Amazon basin of Brazil and Peru, and the Guianan Shield of Guyana, French Guiana, Surinam, and Venezuela) (Wilson and Findley, 1977; Wilson, 2008a). Velazco et al. (2014) identified our Mayo River basin specimen as T. tricolor. This specimen exhibits most of the diagnostic characteristics of the species: unicolored whitish ventral pelage; proximal portion of the fore- arm sparsely haired; circular adhesive disk on the thumb; calcar with two lappets that project posterolaterally from the shaft of the calcar; I2 mesial cusp larger than the distal cusp; both cusps on I2 obliquely arranged relative to the long axis of the toothrow; P1 circular in occlusal view; i3 with two faintly developed accessory cusps on each side (Velazco et al., 2014). One of the diagnostic characteristics of the family Thyropteridae is the lack of postorbital processes, which is seen in all known species (Wilson, 2008a). However our specimen possesses wellmarked postorbital processes on both sides of the skull. The presence of postorbital processes in our specimen could be the result of individual variation or might be indicative of a new species, but without a more comprehensive study that includes molecular data, we continue to identify this individual as a member of the nominate subspecies. With the exception of its postorbital processes, our specimen conforms to previous descriptions of the nominate subspecies and its measurements fall within the range of size variation previously documented.

\section{Family Vespertilionidae Gray, 1821}

Vespertilionidae is the most speciose family in Chiroptera, with a nearly cosmopolitan distribution except in the Arctic and Antarctica. Vespertilionids are characterized by the reduction of the second digit of the wing to the metacarpal and a single small phalanx and the presence of a long tail, reaching the edge of the uropatagium (Koopman, 1994). Two species of Myotis were recorded in one locality during our study.

\section{Myotis caucensis Allen, 1914}

Voucher MATERial: Waqanki: 1 adult female (FMNH 203646), 2 adult males (MUSM 39243, 39244); see table 19 for measurements.

IDENTIFICATION: Myotis is the most diverse and widely distributed bat genus with 126 species recognized (Burgin et al., 2018). The taxonomy and systematics of the genus, especially in the 
New World, is confused and controversial (e.g., LaVal, 1973; Moratelli and de Oliveira, 2011; Moratelli et al., 2011a,b, 2013; Moratelli and Wilson, 2011; Larsen et al., 2012; Mantilla-Meluk and Muñoz-Garay, 2014). Recently, several studies have attempted to clarify the taxonomy of the Myotis nigricans species complex (Larsen et al., 2012; Moratelli et al., 2013; Moratelli and Wilson, 2014). One of the results of these revisions was the recognition of Myotis caucensis as a valid species where previously it had been regarded as a junior synonym of Myotis nigricans osculatii (Wilson, 2008b; Moratelli et al., 2013). M. caucensis occurs along the intermontane valleys of the Andes in Colombia, eastern Ecuador, and Peru and the adjacent Amazon lowlands across an elevational range from ca. 200 to $2600 \mathrm{~m}$ (LaVal, 1973; Moratelli et al., 2013). No subspecies are currently recognized in $M$. caucensis (Moratelli et al., 2013). Our Mayo River basin voucher specimens exhibit the diagnostic characteristics of the species: medium-size (FA $36.0-38.5 \mathrm{~mm}$ ); dorsal pelage silky and unicolored; a fringe of hairs lacking along the trailing edge of the uropatagium; sagittal crest absent; and frontals not steeply sloping (Moratelli et al., 2013). Measurements of our specimens fall within the range of measurements reported for the species.

\section{Myotis riparius Handley, 1960}

Voucher Material: Waqanki: 2 adult females (FMNH 203650; MUSM 39245); see table 19 for measurements.

IDENTIFICATION: We consulted descriptions and measurements of Myotis riparius provided by Handley (1960), LaVal (1973), Simmons and Voss (1998), Brosset and Charles-Dominique (1990), López-González et al. (2001), Moratelli et al. (2013), and Novaes et al. (2017). No subspecies are currently recognized in $M$. riparius (Novaes et al., 2017). Our Mayo River basin voucher specimens exhibit the diagnostic characteristics of the species: fur long and woolly; dorsal pelage unicol- ored; plagiopatagium attached to the foot at the level of the base of the toes; a fringe of hairs lacking along the trailing edge of uropatagium; sagittal and lambdoidal crests present; and occipital region flattened posteriorly (Novaes et al., 2017). Measurements of the Mayo River specimens fall within the range of measurements reported for the species.

REMARKs: One female (MUSM 39245) that we collected was lactating.

\section{Order Rodentia Bowdich, 1821}

Family Cricetidae Fischer, 1817

The cricetid rodents are one of the largest and most successful radiations in mammals. The family is the second largest in Mammalia, second only to murids, comprising 765 species grouped into 142 genera (Pardiñas et al., 2017). Five subfamilies are currently recognized within the family, with only three of those occurring in the New World: Neotominae, Sigmodontinae, and Tylomyinae (Pardiñas et al., 2017).

\section{Subfamily Sigmodontinae Wagner, 1843}

The sigmodontines are the most diverse subfamily of cricetids, with a distribution spanning southern North America to Cape Horn. They occupy a great variety of habitats across an elevational range from sea level to $5000 \mathrm{~m}$ (D'Elía and Pardiñas, 2015; Maestri and Patterson, 2016; Pardiñas et al., 2017).

Tribe Akodontini Vorontsov, 1959

Akodon aerosus Thomas, 1913

Voucher Material: El Diamante: 1 adult female (MUSM 39253); Tingana: 1 adult female (MUSM 39254), 2 adult males (FMNH 203654; MUSM 39255); Waqanki: 5 adult females (FMNH 203466, 203464, 203652; MUSM 39251, 39252), 1 adult male (MUSM 39250); see table 20 for measurements. 
TABLE 19

External and craniodental measurements $(\mathrm{mm})$ and weights $(\mathrm{g})$ of Myotis caucensis and M. riparius

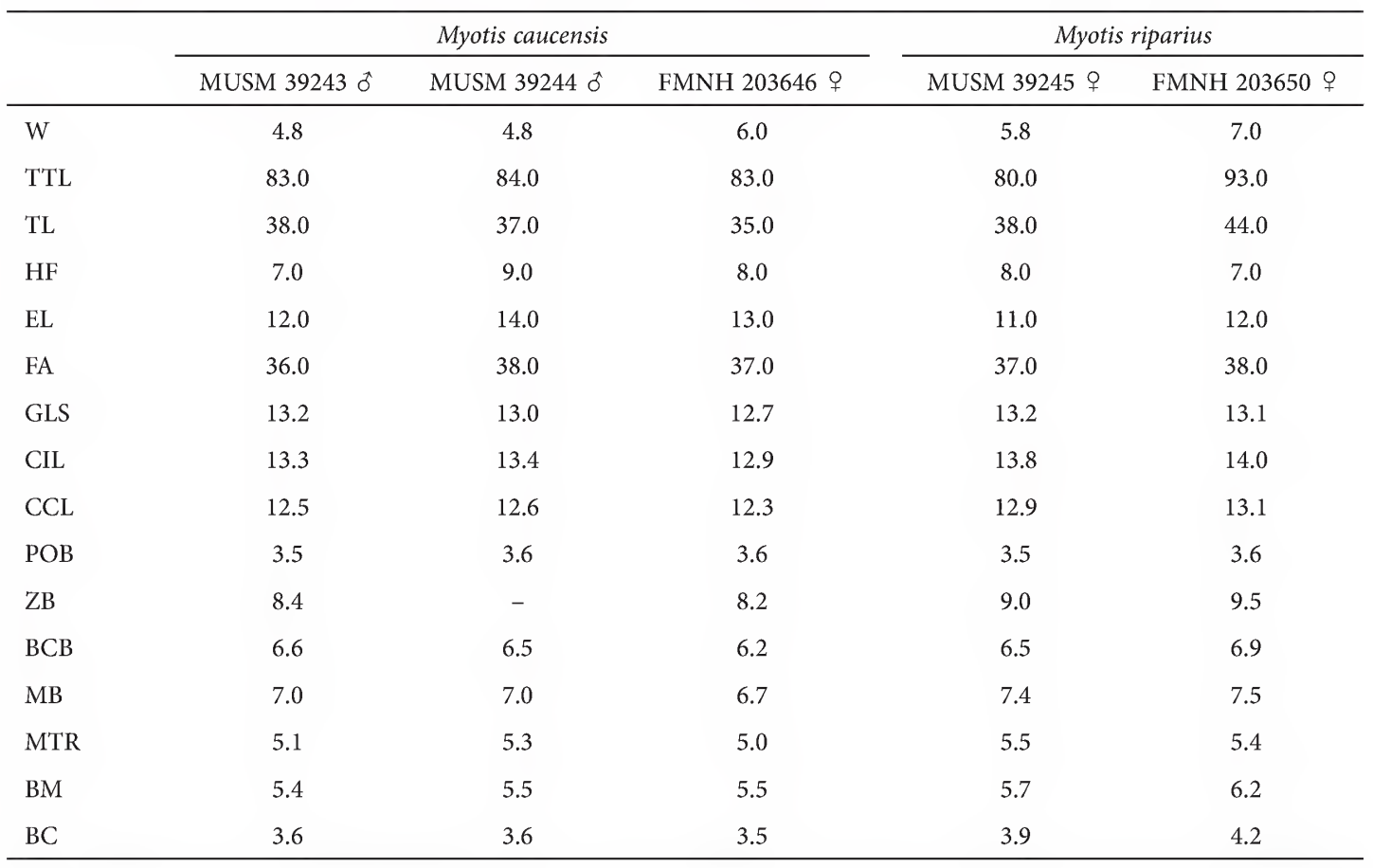

IDENTIFICATION: We consulted descriptions and measurements of Akodon aerosus provided by Myers (1990), Anderson (1997), Jiménez et al. (2013), Pardiñas et al. (2015), and Pardiñas and Cuéllar Soto (2017). No subspecies are currently recognized in A. aerosus (Pardiñas and Cuéllar Soto, 2017). Our Mayo River basin voucher specimens present the diagnostic characteristics of the species: dorsal pelage dark brown, dense, and short; ventral pelage slightly paler than dorsum; ears, forefeet, hind feet, and tail blackish brown; rostrum short and broad; supraorbital ridges smooth and nonbeaded; incisive foramina long, widely open, and with smoothly rounded edges; and broad mesopterygoid fossa (Pardiñas et al., 2015; Pardiñas and Cuéllar Soto, 2017). Measurements of our specimen fall within the range of measurements reported for the species.

Remarks: All of the Mayo River basin specimens were captured either in grassy fields or cultivated areas. A new species of laelapinae mite,
Androlaelaps aerosus, was described by Lareschi and Velazco (2013) based on mites present on Akodon aerosus specimens from the Tingana and Waqanki localities.

Tribe Oryzomyini Vorontsov, 1959

Euryoryzomys macconnelli (Thomas, 1910)

Voucher Material: El Diamante: 2 adult males (FMNH 203468, 203656); see table 21 for measurements.

IDENTIFICATION: We consulted descriptions and measurements of Euryoryzomys macconnelli provided by Patton et al. (2000, as Oryzomys macconnelli), Voss et al. (2001, as Oryzomys macconnelli), Weksler et al. (2006), Weksler and Percequillo (2011), Percequillo (2015a), and Prado et al. (2017a). No subspecies are currently recognized in E. macconnelli (Percequillo, 2015a; Prado et al., 2017a). Euryoryzomys macconnelli is distinguished from other species in the genus by the following combina- 
TABLE 20

External and craniodental measurements ( $\mathrm{mm}$ ) and weights (g) of Akodon aerosus

\begin{tabular}{|c|c|c|}
\hline & 3 males & 7 females \\
\hline W & $35.0,37.0$ & $39.4(20.0-52.0) 7$ \\
\hline TTL & $170.7(163.0-180.0) 3$ & $181.3(170.0-192.0) 6$ \\
\hline $\mathrm{TL}$ & $64.0(61.0-66.0) 3$ & $64.0(49-76) 6$ \\
\hline $\mathrm{HF}$ & $24.3(24.0-25.0) 3$ & $23.3(21.0-25.0) 6$ \\
\hline EL & (15) 2 & $16.0(15.0-18.0) 6$ \\
\hline CIL & $25.3(25.0-25.5) 3$ & $25.7(24.6-27.0) 5$ \\
\hline LD & $7.0(6.8-7.3) 3$ & $7.0(6.1-7.5) 7$ \\
\hline LM & $4.6(4.4-4.8) 3$ & $4.5(4.2-4.7) 7$ \\
\hline BM1 & $1.3(1.3-1.4) 3$ & $1.3(1.2-1.5) 7$ \\
\hline LIF & $5.9(5.7-6.1) 3$ & $6.2(5.3-6.7) 7$ \\
\hline BIF & $2.3(2.2-2.4) 3$ & $2.5(2.3-2.7) 7$ \\
\hline $\mathrm{BPB}$ & $2.9(2.8-3.0) 3$ & $3.0(2.7-3.1) 7$ \\
\hline $\mathrm{BZP}$ & $2.4(2.3-2.5) 3$ & $2.4(2.0-2.6) 7$ \\
\hline LN & $10.1(9.4-10.6) 3$ & $10.6(9.5-11.4) 7$ \\
\hline LIB & $5.4(5.4-5.5) 3$ & $5.5(5.2-5.7) 7$ \\
\hline $\mathrm{BB}$ & $13.1(12.9-13.2) 3$ & $12.8(12.5-13.1) 5$ \\
\hline $\mathrm{ZB}$ & $14.3(14.2-14.5) 3$ & $14.3(14.0-14.8) 6$ \\
\hline
\end{tabular}

tions of characteristics: medium size; fur dense, lax, and long; dorsal pelage reddish brown; skull lacking alisphenoid strut; and lower first molar with an ectolophid (Percequillo, 2015a). Our voucher material conforms to previous descriptions of the species, and measurements fall within the range of size variation previously documented for E. macconnelli.

REMARKs: Both of our specimens were captured in a small coffee plantation. Lareschi and Velazco (2013) reported the mites Androlaelaps fahrenholzi and Gigantolaelaps oudemansi type I from our specimens.

Holochilus sciureus Wagner, 1842

Voucher Material: Waqanki: 1 adult female (MUSM 39257); see table 21 for measurements.
IDENTIFICATION: We consulted descriptions and measurements of Holochilus sciureus provided by Anderson (1997), Patton et al. (2000), Hice and Velazco (2012), Gonçalves et al. (2015), and Prado et al. (2017b). No subspecies are currently recognized in H. sciureus (Prado et al., 2017b). H. sciureus is characterized by the following characteristics: small size, head and body length $123-193 \mathrm{~mm}$, tail length 115-178 mm; dorsal fur yellowish brown, usually mixed with black; sides are paler; ventral pelage whitish; supraorbital crests well developed; incisors opisthodont; and molars tetralophodont (Gonçalves et al., 2015; Prado et al., 2017b). Our specimen conforms to previous descriptions of the species, and measurements fall within the range of size variation previously documented.

Remarks: Our single specimen was captured in a grassland. Lareschi and Velazco (2013) 
TABLE 21

External and craniodental measurements $(\mathrm{mm})$ and weights $(\mathrm{g})$ of Euryoryzomys macconnelli and Holochilus sciureuss

\begin{tabular}{lcccc}
\hline & \multicolumn{2}{c}{ Euryoryzomys macconnelli } & & Holochilus sciureus \\
\cline { 2 - 3 } FMNH 203468 & o & FMNH 203656 o & MUSM 39257 q \\
\hline TTL & 62.0 & 48.0 & 109.0 \\
TL & 255.0 & 254.0 & 288.0 \\
HF & 126.0 & 123.0 & 138.0 \\
EL & 32.0 & 32.0 & 35.0 \\
CIL & 21.0 & 19.0 & 16.0 \\
LD & 28.7 & 26.5 & 33.5 \\
LM & 8.1 & 7.1 & 10.9 \\
BM1 & 4.8 & 4.8 & 6.9 \\
LIF & 1.5 & 1.5 & 2.2 \\
BIF & 5.2 & 4.2 & 7.3 \\
BPB & 2.5 & 2.2 & 2.6 \\
BZP & 3.0 & 2.6 & 2.9 \\
LR & 3.3 & 3.0 & 4.2 \\
LN & -- & -- & 11.6 \\
LIB & -- & -- & 14.1 \\
BB & 5.2 & 5.3 & 4.1 \\
ZB & -- & -- & 14.3 \\
ZL & 16.5 & 15.0 & 19.4 \\
\hline
\end{tabular}

reported the mite Gigantolaelaps mattogrossensis from our specimen.

\section{Hylaeamys perenensis (Allen, 1901)}

Voucher Material: El Diamante: 2 adult females (FMNH 203474; MUSM 39258), 2 juvenile females (FMNH 203478; MUSM 39262), 6 adult males (FMNH 203472, 203480, 203658; MUSM 39259, 39260, 39261), 1 juvenile male (FMNH 203476); Tingana: 10 adult females (FMNH 203484, 203488, 203662, 203664; MUSM 39256, 39264, 39271, 39272, 39274, 39276), 1 juvenile female (FMNH 203482), 13 adult males (FMNH 203486, 203490, 203492, 203494, 203668; MUSM 39263, 39266-39270, 39273, 39277), 7 juvenile males (FMNH 203496, 203660, 203666, 203670,
203678; MUSM 39265, 39275); Waqanki: 1 juvenile male (FMNH 203470); see table 22 for measurements.

IDENTIFICATION: We consulted descriptions and measurements of Hylaeamys perenensis provided by Patton et al. (2000, as Oryzomys perenensis), Weksler et al. (2006), Weksler and Percequillo (2011), Hice and Velazco (2012), Percequillo (2015b), and Brito and Pardiñas (2017a). No subspecies are currently recognized in $H$. perenensis (Percequillo, 2015b; Brito and Pardiñas, 2017a). H. perenensis is distinguished from other species in the genus by the following combination of characteristics: medium size (head and body length 81-169 $\mathrm{mm}$; tail 94-154 mm); tail shorter than head and body length; hind feet with medium-sized hypothenar pads; skull large and robust; incisive foramina 
long, narrow, teardrop shaped (length 3.6-6.0 mm; width 1.5-2.9 mm); roof of mesopterygoid fossa completely ossified; and M2 without a mesofossette and with long paraflexus (Percequillo, 2015b; Brito and Pardiñas, 2017a). Our specimens conform to previous descriptions of the species, and their measurements fall within the range of size variation previously documented.

Remarks: In the Mayo River basin, Hylaeamys perenensis was commonly captured in cultivated areas and flooded forests; it was less commonly captured in a coffee plantation and near a small stream. One pregnant female was recorded at the Tingana location. Lareschi and Velazco (2013) reported the mite Gigantolaelaps oudemansi type I from our specimens.

\section{Hylaeamys yunganus (Thomas, 1902)}

Voucher Material: El Diamante: 2 adult males (MUSM 39278, 39279), 1 juvenile male (FMNH 203498); Tingana: 1 adult male (FMNH 203500); see table 22 for measurements.

IDENTIFICATION: We consulted descriptions and measurements of Hylaeamys yunganus provided by Anderson (1997, as Oryzomys yunganus), Musser et al. (1998, as Oryzomys yunganus), Patton et al. (2000, as Oryzomys yunganus), Voss et al. (2001, as Oryzomys yunganus), Weksler et al. (2006), Weksler and Percequillo (2011), Hice and Velazco (2012), Percequillo (2015b), and Brito and Pardiñas (2017b). No subspecies are currently recognized in Hylaeamys yunganus (Percequillo, 2015b; Brito and Pardiñas, 2017b). Our Mayo River basin specimens exhibit the diagnostic characteristics of the species: tail shorter than head and body length; dorsal fur dense and velvety; claws sparsely covered by ungual tufts; hind feet lacking hypothenar pads; posterior margins of dentary shallowly concave between condyloid and angular processes; M2 with a distinct mesofossette and short paraflexus; and $\mathrm{m} 2$ with a conspicuous entoflexid (Percequillo, 2015b; Brito and Pardiñas, 2017b). Measurements of our speci- mens fall within the range of measurements reported for the species.

Remarks: All our specimens were captured in cultivated areas. Lareschi and Velazco (2013) reported the mites Androlaelaps fahrenholzi and Gigantolaelaps oudemansi type I from our specimens.

\section{Neacomys spinosus (Thomas, 1882)}

Voucher Material: Waqanki: 1 adult female (MUSM 39280), 1 adult male (FMNH 203672); see table 23 for measurements.

IDENTIFICATION: Neacomys spinosus was considered the most widespread species of Neacomys (e.g., Patton et al., 2000; Hice and Velazco, 2012; Weksler and Bonvicino, 2015a) until the taxonomy and systematics of the species was reviewed and its limits were reassessed by Hurtado and Pacheco (2017). The latter authors restricted the distribution of $N$. spinosus to montane cloud forests of the Peruvian departments of Amazonas, San Martín, and Huánuco across an elevational range that extends from 1127 to $2100 \mathrm{~m}$. Neacomys spinosus is distinguished from other congeneric species by the following combination of characteristics: dorsal fur reddish; ventral fur pale white with gray bases; carpal vibrissae short; carpal and metatarsal patches always present; tail long; supraorbital beads moderately developed; alisphenoid strut present; condylar process large and slim; procingulum of M1 anteriorly flattened; posteroloph short; and protoflexus in M1 deep (Hurtado and Pacheco, 2017). Our specimens conform to this emended description of the species, and measurements fall within the range of size variation previously documented.

Remarks: At Mayo River basin, Neacomys spinosus was captured near a small stream. Our specimens were captured at the Waqanki locality that is at an elevation of $970 \mathrm{~m}$, somewhat lower than the minimum elevation $(1127 \mathrm{~m})$ previously reported for the species by Hurtado and Pacheco (2017). Lareschi and Velazco (2013) reported the 
TABLE 22

External and craniodental measurements $(\mathrm{mm})$ and weights (g) of Hylaeamys perenensis and $H$. yunganus

\begin{tabular}{|c|c|c|c|}
\hline & \multicolumn{2}{|c|}{ Hylaeamys perenensis } & \multirow{2}{*}{$\frac{H . \text { yunganus }}{3 \text { males }}$} \\
\hline & 19 males & 12 females & \\
\hline W & $69.3(52.0-96.0) 19$ & $62.8(41.0-85.0) 11$ & $55.3(40.0-80.0) 3$ \\
\hline TTL & $254.5(225.0-283.0) 17$ & $284.4(215.0-273.0) 12$ & $240.7(225.0-267.0) 3$ \\
\hline TL & $115.6(98.0-131.0) 17$ & $111.3(96.0-120.0) 12$ & $116.0(106.0-121.0) 3$ \\
\hline $\mathrm{HF}$ & $30.6(28.0-33.0) 19$ & $29.9(28.0-32.0) 12$ & $28.7(28.0-30.0) 3$ \\
\hline EL & $20.6(18.0-22.0) 19$ & $20.8(20.0-23.0) 12$ & $19.3(18.0-20.0) 3$ \\
\hline CIL & $29.8(27.6-32.1) 17$ & $29.2(27.4-30.9) 11$ & $28.4(27.0-30.9) 3$ \\
\hline LD & $8.7(8.0-9.9) 19$ & $8.5(7.7-9.8) 12$ & $8.0(7.4-9.1) 3$ \\
\hline $\mathrm{LM}$ & $5.0(4.7-5.3) 19$ & $4.9(4.6-5.1) 12$ & $5.1(5.1-5.2) 3$ \\
\hline BM1 & $1.5(1.4-1.7) 19$ & $1.5(1.4-1.6) 12$ & $1.5(1.4-1.6) 3$ \\
\hline LIF & $4.5(4.1-5.0) 19$ & $4.5(4.1-4.9) 12$ & $4.7(4.5-4.9) 3$ \\
\hline BIF & $2.3(2.0-2.6) 19$ & $2.2(1.9-2.4) 12$ & $2.1(1.9-2.3) 3$ \\
\hline $\mathrm{BPB}$ & $3.2(2.8-4.2) 19$ & $3.1(2.8-3.5) 12$ & $2.9(2.7-3.1) 3$ \\
\hline $\mathrm{BZP}$ & $3.9(3.4-4.5) 19$ & $4.0(3.4-4.6) 12$ & $3.7(3.4-3.9) 3$ \\
\hline LN & $12.4(11.0-13.7) 19$ & $12.3(11.2-13.9) 12$ & $12.2(11.5-12.8) 3$ \\
\hline LIB & $5.2(4.9-5.6) 19$ & $5.2(5.0-5.5) 12$ & $5.4(5.3-5.7) 3$ \\
\hline $\mathrm{BB}$ & $13.5(12.8-14.2) 17$ & $13.4(12.6-13.9) 12$ & $13.4(13.0-13.6) 3$ \\
\hline $\mathrm{ZB}$ & $17.0(15.7-18.7) 19$ & $16.3(13.8-17.6) 12$ & $16.3(15.6-17.4) 3$ \\
\hline
\end{tabular}

mites Gigantolaelaps intermedia, Laelaps boultoni, and Laelaps neacomydis from our specimens.

Nectomys rattus (Pelzeln, 1883)

Voucher Material: El Diamante: 1 adult female (MUSM 39281); see table 23 for measurements.

IDENTIFICATION: We consulted descriptions and measurements of Nectomys rattus provided by Hershkovitz (1944, as Nectomys squamipes melanius), Voss et al. (2001, as Nectomys melanius), Bonvicino and Weksler (2015), and Chiquito et al. (2017). No subspecies are currently recognized in Nectomys rattus (Bonvicino and Weksler, 2015; Chiquito et al., 2017). Nectomys rattus is distinguished from other species in the genus by the following combination of characteristics: dorsal fur grayish brown; venter fur pale gray; hind feet lacking hypothenar pads; forefeet with distinct rudiment of thumb with nail; tail scaly but moderately haired; lacrimals contacting the maxillary bone; interparietal much wider than long; and dorsolateral exposition of the exoccipital reduced (Bonvicino and Weksler, 2015; Chiquito et al., 2017). Our specimen conforms to previous descriptions of the species, and its measurements fall within the range of size variation previously documented.

Remarks: Our single specimen was captured in a cultivated area. Lareschi and Velazco (2013) reported the mite Gigantolaelaps goyanensis from our specimen. 
TABLE 23

External and craniodental measurements ( $\mathrm{mm}$ ) and weights (g) of Neacomys spinosus, Nectomys rattus, and Oecomys bicolor

\begin{tabular}{|c|c|c|c|c|c|}
\hline & \multicolumn{2}{|c|}{ Neacomys spinosus } & \multirow{2}{*}{$\begin{array}{l}\text { Nectomys rattus } \\
\text { MUSM } 39281 \%\end{array}$} & \multicolumn{2}{|c|}{ Oecomys bicolor } \\
\hline & MUSM 39280 & FMNH 203672 ๙ & & FMNH 203502 ఠ & FMNH 203674 \\
\hline W & 10.6 & 21.5 & 108.0 & 26.9 & 30.0 \\
\hline TTL & 142.0 & 173.0 & 302.0 & 195.0 & 205.0 \\
\hline TL & 72.0 & 80.0 & 156.0 & 104.0 & 110.0 \\
\hline $\mathrm{HF}$ & 21.0 & 22.0 & 44.0 & 21.0 & 21.0 \\
\hline EL & 15.0 & 15.0 & 18.0 & 16.0 & 14.0 \\
\hline CIL & 17.9 & 20.7 & 33.7 & -- & 24.4 \\
\hline LD & 4.8 & 6.0 & 9.3 & 6.5 & 7.1 \\
\hline LM & 3.2 & 3.3 & 7.4 & 3.8 & 4.0 \\
\hline BM1 & 1.1 & 1.2 & 2.1 & 1.3 & 1.2 \\
\hline LIF & 3.0 & 3.9 & 5.8 & 4.3 & 4.6 \\
\hline BIF & 1.7 & 1.7 & 2.8 & 1.9 & 2.0 \\
\hline ВРВ & 2.1 & 2.3 & 2.9 & 2.4 & 2.4 \\
\hline BZP & 1.8 & 2.0 & 3.6 & 2.3 & 2.4 \\
\hline LR & 6.0 & 7.3 & -- & -- & -- \\
\hline LIB & 4.3 & 4.3 & 6.6 & 4.7 & 4.8 \\
\hline ВВ & 10.6 & 10.8 & -- & -- & -- \\
\hline $\mathrm{ZB}$ & 11.1 & 11.8 & 19.8 & 13.9 & 13.9 \\
\hline
\end{tabular}

Oecomys bicolor (Tomes, 1860)

Voucher Material: Tingana: 2 adult males (FMNH 203502, 203674); see table 23 for measurements.

IDENTIFICATION: We consulted descriptions and measurements of Oecomys bicolor provided by Anderson (1997), Patton et al. (2000), Voss et al. (2001), Carleton et al. (2009), Hice and Velazco (2012), Carleton and Musser (2015), Ruelas and Pardiñas (2017), and Suárez-Villota et al. (2018). No subspecies are currently recognized in $\mathrm{O}$. bicolor (Carleton and Musser, 2015; Ruelas and Pardiñas, 2017). Oecomys bicolor is distinguished from other congeneric species by the following combination of characteristics: dorsal fur ranging from orange brown to rufous brown; ventral pelage uniformly white; tail (105\%-112\% of head-body length) unicolored with a moderately penciled tip; skull robust, with short rostrum, narrow interorbit with finely beaded supraorbital ledges, and relatively inflated braincase; zygomatic arches slightly narrower rostrally and divergent toward braincase; bony palate with a pair of prominent posterolateral palatal pits; carotid circulatory pattern complete (sphenofrontal foramen and squamosoalisphenoid groove present, stapedial foramen small but present); and ectotympanic bullae small, exposing much of medial periotic (Carleton and Musser, 2015; Ruelas and Pardiñas, 2017). Our specimens conform to previous descriptions of the species, and their measurements fall within the range of size variation previously documented.

REMARKs: Our specimens were captured in a flooded forest. Lareschi and Velazco (2013) 
reported the mites Androlaelaps fahrenholzi, Gigantolaelaps tiptoni, and Laelaps furmani from our specimens.

\section{Oligoryzomys destructor (Tschudi, 1844)}

Voucher Material: El Diamante: 1 adult male (FMNH 203504); Tingana: 2 adult males (MUSM 39285, 39286); see table 24 for measurements.

IDENTIFICATION: We consulted descriptions and measurements of Oligoryzomys destructor provided by Anderson (1997), Weksler and Bonvicino (2015b), Pardiñas (2017a), and Hurtado and D’Elía (2019). Currently two subspecies are recognized: $O$. d. destructor (eastern slope of the Andes [between 1600 and $3600 \mathrm{~m}$ ] from southern Marañon River to southern Peru) and $O . d$. spodiurus (western slope of the Andes [between 1200 and $2900 \mathrm{~m}$ ] from northern Ecuador to northern Marañon River in Peru) (Hurtado and D'Elía, 2019). Oligoryzomys destructor is characterized by the following characteristics: upper body reddish brown, interspersed with numerous black hairs and some gray ones with light tips; ventral fur pale yellow with a gray base; transition between ventral and dorsal coloration well defined; tail markedly bicolored; tail longer than head and body length; dorsal surfaces of feet covered by short silver-gray hair, with hairs of nail base very long; internal ear surfaces with short, pale brown hair, external surface covered with longer, blackish hairs; eight mammae present; opening of stapedial foramen large (carotid circulation pattern 2); zygomatic notch deep; interorbital constriction narrower than external breadth across molar rows; posterior borders of incisive foramina reach the anterior borders of $\mathrm{Ml}$; anterior border of mesopterygoid fossa curved; and short and thin coronoid process (Weksler and Bonvicino, 2015b; Pardiñas, 2017a; Hurtado and D'Elía, 2019). Our specimen conforms to previous descriptions of the nominate subspecies, and measurements fall within the range of size variation previously documented.
Remarks: At Mayo River basin, two of our specimens of Oligoryzomys destructor were captured at the Tingana locality which lies at an elevation of $815 \mathrm{~m}$, far lower than the lowest elevation $(1600 \mathrm{~m})$ reported by Hurtado and D'Elía (2019) for the nominal subspecies. All three specimens were captured in cultivated areas. Lareschi and Velazco (2013) reported the mites Gigantolaelaps tiptoni and Mysolaelaps parvispinosus from our specimens.

Oligoryzomys microtis (Allen, 1916)

Voucher Material: El Diamante: 3 adult females (MUSM 39283, 39284; FMNH 203506); Tingana: 1 adult male (FMNH 203676); Waqanki: 1 adult female (MUSM 39282); see table 24 for measurements.

IDENTIFICATION: We consulted descriptions and measurements of Oligoryzomys microtis provided by Olds and Anderson (1987; as Oryzomys microtis), Anderson (1997), Patton et al. (2000), Voss et al. (2001), Hice and Velazco (2012), Weksler and Bonvicino (2015b), and Pardiñas (2017b). No subspecies are currently recognized in $O$. microtis (Weksler and Bonvicino, 2015b; Pardinas, 2017b). Oligoryzomys microtis is characterized by the following characteristics: dorsal fur dull yellowish brown, finely lined with blacktipped hairs; ventral fur white; upper surfaces of feet thinly covered with light buffy brown hairs; ears small, brownish, and nearly naked; eight mammae; stapedial foramen with large opening, indicating carotid circulation pattern 2 (Weksler and Bonvicino, 2015b; Pardiñas, 2017b). Our specimens conform to previous descriptions of the species, and measurements fall within the range of size variation previously documented.

Remarks: The specimen collected at the Tingana location was caught at the edge of a renacal (flooded forest of Coussapoa trinervia). All the other specimens were caught in cultivated areas. Lareschi and Velazco (2013) reported the mite Laelaps paulistanensis from our specimens. 
TABLE 24

External and craniodental measurements $(\mathrm{mm})$ and weights $(\mathrm{g})$ of Oligoryzomys destructor and $O$. microtis

\begin{tabular}{|c|c|c|c|}
\hline & \multirow{2}{*}{$\frac{\text { Oligoryzomys destructor }}{3 \text { males }}$} & \multicolumn{2}{|c|}{ O. microtis } \\
\hline & & FMNH 203676 ఠ & 4 females \\
\hline W & $23.5(15.5-30.5) 3$ & 24.0 & $17.5(16.0-20.0) 4$ \\
\hline TTL & $185.0(170.0-195.0) 3$ & 204.0 & $175.8(165.0-188.0) 4$ \\
\hline TL & $98.3(90.0-105.0) 3$ & 107.0 & $98.3(91.0-106.0) 4$ \\
\hline $\mathrm{HF}$ & $22.0(21.0-23.0) 3$ & 22.0 & $21.5(21.0-22.0) 4$ \\
\hline EL & $13.3(12.0-14.0) 3$ & 16.0 & $13.5(12.0-15.0) 4$ \\
\hline CIL & $21.2(19.5-22.4) 3$ & 21.3 & $19.7(19.2-20.0) 4$ \\
\hline LD & $5.9(5.1-6.5) 3$ & 5.8 & $5.3(5.1-5.5) 4$ \\
\hline LM & $3.4(3.3-3.4) 3$ & 3.3 & $3.3(3.1-3.4) 4$ \\
\hline BM1 & $(1.0) 3$ & 1.0 & $1.0(0.9-1.1) 4$ \\
\hline LIF & $4.0(3.8-4.2) 3$ & 3.9 & $3.7(3.4-3.8) 4$ \\
\hline BIF & $1.7(1.6-1.7) 3$ & 1.6 & $1.8(1.6-1.9) 4$ \\
\hline BPB & $2.3(2.2-2.4) 3$ & 2.1 & $2.2(2.1-2.4) 4$ \\
\hline $\mathrm{BZP}$ & $2.2(2.0-2.3) 3$ & 2.0 & $2.0(1.9-2.2) 4$ \\
\hline LR & $7.2(6.5-7.6) 3$ & 7.3 & $6.6(6.3-6.9) 4$ \\
\hline LIB & $3.8(3.7-3.9) 3$ & 3.7 & $3.7(3.6-3.8) 4$ \\
\hline BB & $10.7(10.4-10.9) 3$ & 10.4 & $10.5(10.4-10.7) 4$ \\
\hline $\mathrm{ZB}$ & $12.5(12.0-12.8) 3$ & 12.3 & $11.6(11.3-11.9) 4$ \\
\hline
\end{tabular}

Family Erethizontidae Bonaparte, 1845

The New World porcupines in the family Erethizontidae are medium-to-large sized nocturnal, arboreal, herbivorous rodents that have their bodies covered with spines used for defense (Barthelmess, 2016). Currently, the family comprises 17 species that are grouped into three genera, two of these monotypic (Chaetomys and Erethizon) (Voss, 2015; Barthelmess, 2016). The third, Coendou, contains most of the diversity and its species are distributed in Central and South America (Barthelmess, 2016).

\section{Coendou bicolor (Tschudi, 1844)}

VOUCher Material: Waqanki: 1 subadult of unknown sex (MUSM 39287); see table 25 for measurements.
IDENTIFICATION: Description and measurements of Coendou bicolor have been provided by Anderson (1997), Voss (2011, 2015), and Barthelmess (2016). No subspecies are currently recognized in C. bicolor (Voss, 2015; Barthelmess, 2016). Our Mayo River basin specimen is a subadult, and all measurements of this individual fall outside or at the lower end of the range of variation previously reported for the species. Nonetheless, our specimen exhibits all the diagnostic characteristics of the species (e.g., quills uniformly bicolored and abruptly shorter on lower back and rump than on shoulders and upper back; frontal sinuses inflated; and roof of external auditory meatus smooth) (Voss, 2015; Barthelmess, 2016). Based on the analysis of cytochrome $b$ sequences, Voss et al. (2013) confirmed the identification our specimen as Coendou bicolor. 
TABLE 25

External and craniodental measurements $(\mathrm{mm})$ and weight (g) of Coendou bicolor

\begin{tabular}{lc}
\hline \hline & MUSM 39287 \\
\hline W & 1270 \\
TTL & 670 \\
TL & 320 \\
HF & 69 \\
EL & 20 \\
CIL & 69.0 \\
LD & 17.4 \\
MTR & 17.4 \\
LM & 14.2 \\
BM1 & 4.7 \\
LIF & 6.0 \\
BIF & 3.6 \\
BPB & 4.6 \\
LN & 20.9 \\
BB & 35.5 \\
ZB & 47.7 \\
ZL & 27.9 \\
\hline
\end{tabular}

REMARKS: Our specimen was shot at night $(22: 15 \mathrm{hr})$ while it was feeding on a tree above a stream. Nava et al. (2010) identified Amblyomma longirostre ticks collected from our specimen. These ticks represent the first record of this ectoparasite in Peru (Nava et al., 2010).

\section{DISCUSSION}

The eastern versant of the Central Andes of Peru is one of the major centers of endemism in the Neotropics. However, its mammalian diversity remains poorly studied. Most recent studies have focused on its global flagship primates, the yellowtailed woolly monkey (Lagothrix flavicauda) and the Río Mayo titi (Callicebus oenanthe) (e.g., DeLuycker, 2006, 2007; Shanee et al., 2007a, b; Aldrich et al., 2008; Bóveda-Penalba et al., 2009; Buckingham and Shanee, 2009; Vermeer et al., 2011). Our inventory focused mainly on three localities along the Mayo River basin that exhibited different degrees of anthropogenic disturbances, ranging from highly disturbed (El Diamante) to more moderate disturbance (Tingana). Because our fieldwork was performed during the end of the rainy season, we were unable to assess the mammal diversity during the dry or at the start of the rainy season. Ideally, inventories should be conducted on at least four occasions, including two wet and two dry season samples per year, over at least two years. Despite the high rate of deforestation in the region, the diversity of mammals remains high in the Mayo River basin. In our three-week long inventory, we collected 47 mammal species: five marsupials, 31 bats, and 11 rodents. Had we supplemented our sampling methods for nonvolant mammals with camera traps and diurnal and nocturnal transects, which effectively document medium-sized and larger mammals, a number of additional species would likely have been added. Likewise for bats, the inclusion of harp traps and canopy nets in our inventory would likely have added additional species.

All of our marsupial specimens were either shot (Didelphis) or captured with Victor snap traps (Marmosa and Marmosops). They were captured in a variety of habitats ranging from chicken coops (Didelphis) and farmlands to secondary and flooded forests.

Most of the Mayo River bat records are relevant to ongoing studies of bat taxonomy and biogeography in the region. Our single record of Carollia sp. sensu Solari and Baker (2006) is the southernmost record of this undescribed species, otherwise known to occur in Ecuador and Peru north of the Amazon and Marañon Rivers. This undescribed species is sister to $C$. benkeithi, but in spite of the large cyt- $b$ divergence between these two taxa (7\%), we were unable to find discrete morphological characteristics that would help discriminate between these two taxa. Likewise, no differences between $C$. benkeithi and the new species were found in geometric morphometric analyses by Ruelas and López (2018) involving the shape of the skull and mandible. 
Recently, Pacheco et al. (2018) questioned the presence of Anoura geoffroyi in Peru based on their interpretation of the revision of the Anoura geoffroyi complex by Mantilla-Meluk and Baker (2010). However, we captured four individuals that exhibit all the diagnostic characteristics of $A$. geoffroyi, confirming the presence of that species in Peru. Earlier records document another species of the Anoura geoffroyi complex, Anoura peruana, at mid to high elevations in the Andes. A. geoffroyi is present at low to middle elevations east of the Andes.

In the past decade, bats of the genus Sturnira have been the focus of numerous systematic and taxonomic revisions, and several species had been described based on their results (e.g., MartínezArias et al., 2010; Jarrín-V and Kunz, 2011; Jarrín-V and Clare, 2013; Velazco and Patterson, 2013, 2014; Hernández-Canchola and León-Paniagua, 2017; Molinari et al., 2017). One of the most widespread and widely studied species of the genus, S. lilium, was recently reviewed and split into seven taxa, two of them undescribed (Velazco and Patterson, 2013). One of these species, designated "Sturnira new species 2," was later described as Sturnira bakeri (Velazco and Patterson, 2014) and this transAndean form is sister to the Central American species Sturnira parvidens (Hernández-Canchola and León-Paniagua, 2017). The other, "Sturnira new species 3," is described here as Sturnira giannae and has the widest distribution in the genus. Although we now have a better understanding of the taxonomy and systematics of the S. lilium complex, several issues still need attention, including the role of the Huancabamba Depression in the diversification and genetic diversity of $S$. giannae. Another remaining issue is the reapportionment to the newly delimited species of all the natural history and other information (e.g., fossils, karyotypes, ectoparasites, endoparasites, etc.) reported under the name Sturnira lilium (sensu lato).

Our single specimen of Thyroptera tricolor exhibits a postorbital process, a characteristic absent in any known species of the genus. The presence of this process could represent indi- vidual variation or signal an undescribed species. Although only five species are extant (Velazco et al., 2014), thyropterids have a remarkable fossil record that dates back to the Miocene of Colombia and documents evolutionary stasis in dental dimensions (Czaplewski, 1996, 1997; Czaplewski et al., 2003; ReyesAmaya et al., 2016). A comprehensive study that incorporates both these fossils and molecular data from specimens taken from both versants of the Andes is necessary to unravel the systematics of this charismatic widespread species.

Neacomys spinosus and Oligoryzomys destructor were collected in the Mayo River basin below the lowest elevations reported for their elevational ranges. We collected Neacomys spinosus at $970 \mathrm{~m}$ which is lower than the $1127 \mathrm{~m}$ previously reported by Hurtado and Pacheco (2017) as the lower limit of the elevational range for the species. We captured Oligoryzomys destructor at two localities at $815 \mathrm{~m}$ and $1078 \mathrm{~m}$, both of which are far lower than the lower limit reported for the species of $1600 \mathrm{~m}$ by Hurtado and D'Elía (2019). These expansions of the elevational range of these two species are evidence of the incomplete knowledge of small mammals in the area.

The high rate of anthropogenic disturbances in the Mayo River basin threatens the biodiversity of one the most diverse regions in the Andes, home to endemic species like Neacomys spinosus, Lagothrix flavicauda, and Callicebus oenanthe. The rich small-mammal diversity documented by our survey highlights the need to conduct additional inventories to document its composition and to develop monitoring programs to ensure its continued persistence in the face of development.

\section{ACKNOWLEDGMENTS}

We are grateful to Richard Cadenillas and Sandra Velazco for their assistance in the field, and José Altamirano for his hospitality during the fieldwork. We are grateful to the curators and support staff who hosted visits, loaned specimens, and man- 
aged those loans: Eileen Westwig (AMNH; now at Oxford University Museum of Natural History); John Phelps and the late Bill Stanley (FMNH); and Víctor Pacheco (MUSM). Camilo A. CalderónAcevedo (Anoura), Juan F. Díaz-Nieto (Marmosops), Natalí Hurtado (Oligoryzomys), and Robert Voss (Coendou) shared their knowledge on the taxonomy of specific taxa. Jorge Carrera, Ana Cristyna Reis Lacerda, Christian Loayza, and Edgar Rengifo all helped us find relevant literature. Alfred Gardner, Kerry Kline, and Nancy Simmons read our manuscript and made helpful suggestions to improve it. We are particularly grateful to Anneke van Heteren (ZSM) and Louise Tomsett (BMNH) for kindly furnishing photographs of the holotypes of Phyllostoma fumarium and Sturnira spectrum, respectively. Alex Borisenko and Marco Tschapka kindly allowed us to reproduce photographs of Sturnira giannae. Field research was supported by a National Science Foundation Grant (OISE 0630149 to BDP and PMV) and the Marshall Field III Fund of FMNH.

\section{REFERENCES}

Aldrich, B.C., L. Molleson, and K.A.I. Nekaris. 2008. Vocalizations as a conservation tool: an auditory survey of the Andean titi monkey Callicebus oenanthe Thomas, 1924 (Mammalia: Primates: Pitheciidae) at Tarangue, northern Peru. Contributions to Zoology 77: 1-6.

Alvarez, J., M.R. Willig, J.K. Jones, Jr., and W.D. Webster. 1991. Glossophaga soricina. Mammalian Species 379: 1-7.

Andersen, K. 1908. A monograph of the chiropteran genera Uroderma, Enchisthenes, and Artibeus. Proceedings of the Zoological Society of London 78: 203-319.

Anderson, S. 1997. Mammals of Bolivia: taxonomy and distribution. Bulletin of the American Museum of Natural History 231: 1-652.

Arroyo-Cabrales, J. 2008a ("2007"). Genus Mesophylla O. Thomas, 1901. In A.L. Gardner (editor), Mammals of South America, vol. 1: Marsupials, xenarthrans, shrews, and bats: 327-329. Chicago: University of Chicago Press.

Arroyo-Cabrales, J. 2008b ("2007"). Genus Vampyressa O. Thomas, 1900. In A.L. Gardner (editor), Mam- mals of South America, vol. 1: Marsupials, xenarthrans, shrews, and bats: 346-350. Chicago: University of Chicago Press.

Bai, Y., et al. 2012. Prevalence and diversity of Bartonella spp. in bats in Peru. American Journal of Tropical Medicine and Hygiene 87: 518-523.

Baker, R.J., and H.H. Genoways. 1976. A new species of Chiroderma from Guadeloupe, West Indies (Chiroptera: Phyllostomatide). Occasional Papers of the Museum of Texas Tech University 39: 1-9.

Baker, R.J., R. Fonseca, D. Parish, C. Phillips, and F. Hoffmann. 2004. New bat of the genus Lophostoma (Phyllostomidae: Phyllostominae) from northwestern Ecuador. Occasional Papers of the Museum of Texas Tech University 232: 1-16.

Baker, R.J., S. Solari, A.L. Cirranello, and N.B. Simmons. 2016. Higher level classification of phyllostomid bats with a summary of DNA synapomorphies. Acta Chiropterologica 18: 1-38.

Barthelmess, E.L. 2016. Family Erethizontidae (New World porcupines). In D.E. Wilson, T.E. Lacher, Jr., and R.A. Mittermeier (editors), Handbook of the mammals of the world: 372-397. Barcelona: Lynx Edicions.

Bezerra, A.M.R., F. Escarlate-Tavares, and J.S. MarinhoFilho. 2005. First record of Thyroptera discifera (Chiroptera: Thyropteridae) in the Cerrado of central Brazil. Acta Chiropterologica 7: 165-170.

Bonvicino, C.R., and M. Weksler. 2015. Genus Nectomys Peters, 1861. In J.L. Patton, U.F.J. Pardiñas, and G. D’Elía (editors), Mammals of South America, vol. 2: Rodents: 369-377. Chicago: University of Chicago Press.

Bóveda-Penalba, A.J., J. Vermeer, F. Rodrigo, and F. Guerra-Vásquez. 2009. Preliminary report on the distribution of Callicebus oenanthe on the eastern feet of the Andes. International Journal of Primatology 30: 467-480.

Bowles, J.B., J.B. Cope, and E.A. Cope. 1979. Biological studies of selected Peruvian bats of Tingo María, departamento de Huánuco. Transactions of the Kansas Academy of Science 82: 1-10.

Brito, J., and U.F.J. Pardiñas. 2017a. Western Amazonian rice rat Hylaeamys perenensis. In D.E. Wilson, T.E. Lacher, Jr., and R.A. Mittermeier (editors), Handbook of the mammals of the world: 429. Barcelona: Lynx Edicions.

Brito, J., and U.F.J. Pardiñas. 2017b. Yungas rice rat Hylaeamys yunganus. In D.E. Wilson, T.E. Lacher, Jr., and R.A. Mittermeier (editors), Handbook of the mammals of the world: 429. Barcelona: Lynx Edicions. 
Brosset, A., and P. Charles-Dominique. 1990. The bats from French Guiana: a taxonomic, faunistic and ecological approach. Mammalia 54: 509-560.

Brosset, A., and G. Dubost. 1967. Chiroptères de la Guyane Française. Mammalia 31: 583-594.

Buckingham, F., and S. Shanee. 2009. Conservation priorities for the Peruvian yellow-tailed woolly monkey (Oreonax flavicauda): a GIS risk assessment and gap analysis. Primate Conservation 24: 65-71.

Burgin, C.J., J.P. Colella, P.L. Kahn, and N.S. Upham. 2018. How many species of mammals are there? Journal of Mammalogy 99: 1-14.

Butchart, S.H.M., R. Barnes, C.W.N. Davies, M. Fernandez, and N. Seddon. 1995. Threatened mammals of the Cordillera de Colán, Peru. Oryx 29: 275-281.

Cabrera, A. 1958. Catálogo de los mamiferos de América del Sur. Revista del Museo Argentino de Ciencias Naturales "Bernardino Rivadavia," Ciencias Zoológicas 4: 1-308.

Carleton, M.D., and G.G. Musser. 2015. Genus Oecomys Thomas, 1906. In J.L. Patton, U.F.J. Pardiñas, and G. D’Elía (editors), Mammals of South America, vol. 2: Rodents: 393-417. Chicago: University of Chicago Press.

Carleton, M.D., L.H. Emmons, and G.G. Musser. 2009. A new species of the rodent genus Oecomys (Cricetidae: Sigmodontinae: Oryzomyini) from eastern Bolivia, with emended definitions of $O$. concolor (Wagner) and O. mamorae (Thomas). American Museum Novitates 3661: 1-32.

Carter, D.C., and P.G. Dolan. 1978. Catalogue of type specimens of Neotropical bats in selected European museums. Special Publication of the Museum of Texas Tech University 15: 1-136.

Ceballos Bendezú, I. 1968. Quirópteros del departamento de Loreto (Perú). Revista de la Facultad de Ciencias, Universidad Nacional de San Antonio Abad del Cuzco 2: 7-60.

Cerqueira, R., and C.J. Tribe. 2008 (“2007”). Genus Didelphis Linnaeus, 1758. In A.L. Gardner (editor), Mammals of South America, vol. 1: Marsupials, xenarthrans, shrews, and bats: 17-25. Chicago: University of Chicago Press.

Charles-Dominique, P. 1986. Inter-relations between frugivorous vertebrates and pioneer plants: Cecropia, birds and bats in French Guiana. In A. Estrada and T.H. Fleming (editors), Frugivores and seed dispersal: 119-135. Dordrecht: Springer Netherlands.

Charles-Dominique, P. 1993. Speciation and coevolution: an interpretation of frugivory phenomena. Vegetatio 107/108: 75-84.
Charles-Dominique, P., and A. Cockle. 2001. Frugivory and seed dispersal by bats. In F. Bongers, P. CharlesDominique, P.-M. Forget, and M. Théry (editors), Nouragues: dynamics and plant-animal interactions in a Neotropical rainforest: 207-216. Dordrecht: Kluwer Academic Publishers.

Chiquito, E.A., J.R. Prado, and A.R. Percequillo. 2017. South American water rat Nectomys rattus. In D.E. Wilson, T.E. Lacher, Jr., and R.A. Mittermeier (editors), Handbook of the mammals of the world: 448 . Barcelona: Lynx Edicions.

Cirranello, A.L., N.B. Simmons, S. Solari, and R.J. Baker. 2016. Morphological diagnoses of higherlevel phyllostomid taxa (Chiroptera: Phyllostomidae). Acta Chiropterologica 18: 39-71.

Cloutier, D., and D.W. Thomas. 1992. Carollia perspicillata. Mammalian Species 417: 1-9.

Czaplewski, N.J. 1996. Thyroptera robusta Czaplewski, 1966, is a junior synonym of Thyroptera lavali Pine, 1993 (Mammalia: Chiroptera). Mammalia 60: 153-156.

Czaplewski, N.J. 1997. Chiroptera. In R.F. Kay, R.H. Madden, R.L. Cifelli, and J.J. Flynn (editors), Vertebrate Palaeontology in the Neotropics: the Miocene fauna of La Venta, Colombia: 410-430. Washington D.C.: Smithsonian Institution Press.

Czaplewski, N.J., M. Takai, T. Naeher, N. Shigehara, and T. Setoguchi. 2003. Additional bats from the middle Miocene La Venta fauna of Colombia. Revista de la Academia Colombiana de Ciencias 27: 263-282.

Dávalos, L.M. 2004. A new Chocoan species of Lonchophylla (Chiroptera: Phyllostomidae). American Museum Novitates 3426: 1-14.

Dávalos, L.M., and A. Corthals. 2008. A new species of Lonchophylla (Chiroptera: Phyllostomidae) from the eastern Andes of northwestern South America. American Museum Novitates 3635: 1-16.

Dávalos, L.M., P.M. Velazco, O.M. Warsi, P.D. Smits, and N.B. Simmons. 2014. Integrating incomplete fossils by isolating conflictive signal in saturated and non-independent morphological characters. Systematic Biology 63: 582-600.

Davis, W.B. 1968. Review of the genus Uroderma (Chiroptera). Journal of Mammalogy 49: 676-698.

Davis, W.B. 1970. A review of the small fruit bats (genus Artibeus) of Middle America: part II. Southwestern Naturalist 14: 389-402.

Davis, W.B. 1984. Review of the large fruit-eating bats of the Artibeus "lituratus" complex (Chiroptera: Phyllostomidae) in Middle America. Occasional Papers of the Museum of Texas Tech University 93: $1-16$. 
de Foresta, H., P. Charles-Dominique, C. Erard, and M.-F. Prévost. 1984. Zoochorie et premiers stades de la régénération naturelle après coupe en forêt guyanaise. Revue décologie: La Terre et la Vie 39: 369-400.

de la Sancha, N., G. D’Elía, and P. Teta. 2011. Systematics of the subgenus of mouse opossums Marmosa (Micoureus) (Didelphimorphia, Didelphidae) with noteworthy records from Paraguay. Mammalian Biology 77: 229-236.

de la Torre, L. 1959. A new species of bat of the genus Sturnira (Phyllostomidae) from the Island of Trinidad, West Indies. Natural History Miscellanea 166: $1-6$.

de la Torre, L. 1966. New bats of the genus Sturnira (Phyllostomidae) from the Amazonian lowlands of Peru and the Windward Islands, West Indies. Proceedings of the Biological Society of Washington 79: 267-272.

de la Torre, L., and A. Schwartz. 1966. New species of Sturnira (Chiroptera: Phyllostomidae) from the islands of Guadeloupe and Saint Vincent, Lesser Antilles. Proceedings of the Biological Society of Washington 79: 297-304.

D’Elía, G., and U.F.J. Pardiñas. 2015. Subfamily Sigmodontinae Wagner, 1843. In J.L. Patton, U.F.J. Pardiñas, and G. D'Elía (editors), Mammals of South America, vol. 2: Rodents: 63-70. Chicago: University of Chicago Press.

DeLuycker, A.M. 2006. Preliminary report and conservation status of the Río Mayo titi monkey, Callicebus oenanthe Thomas, 1924, in the Alto Mayo Valley, northeastern Peru. Primate Conservation 21: 33-39.

DeLuycker, A.M. 2007. Notes on the yellow-tailed woolly monkey (Oreonax flavicauda) and its status in the protected forest of Alto Mayo, northern Peru. Primate Conservation 22: 41-47.

de Thoisy, B., et al. 2016. Bioecological drivers of rabies virus circulation in a Neotropical bat community. PLoS Neglected Tropical Diseases 10 (1): e0004378.

Díaz, M.M., S. Solari, L.F. Aguirre, L.M.S. Aguiar, and R.M. Barquez. 2016. Clave de identificación de los murciélagos de Sudamérica. Publicación Especial, PCMA (Programa de Conservación de los Murciélagos de Argentina) 2: 1-160.

Díaz-Nieto, J.F. 2012. New records of Marmosops noctivagus (Tschudi, 1845) (Didelphimorpia: Didelphidae) and first record of Marmosops bishopi (Pine, 1981) for Colombia. Check List 8: 805-809.

Díaz-Nieto, J.F., and R.S. Voss. 2016. A revision of the didelphid marsupial genus Marmosops, part 1. Spe- cies of the subgenus Sciophanes. Bulletin of the American Museum of Natural History 402: 1-70.

Díaz-Nieto, J.F., M. Gomez-Laverde, and C. SanchezGiraldo. 2011. Rediscovery and redescription of Marmosops handleyi (Pine, 1981) (Didelphimorphia: Didelphidae), the least known Andean Slender Mouse Opossum. Mastozoologia Neotropical 18: 45-61.

Díaz-Nieto, J.F., S.A. Jansa, and R.S. Voss. 2016. DNA sequencing reveals unexpected Recent diversity and an ancient dichotomy in the American marsupial genus Marmosops (Didelphidae: Thylamyini). Zoological Journal of the Linnean Society 176: 914-940.

dos Reis, N.R., and J.-L. Guillaumet. 1983. Les chauvessouris frugivores de la région de Manaus et leur rôle dans la dissémination des espèces végétales. Revue d'écologie: La Terre et la Vie 38: 147-169.

dos Reis, N.R., and A.L. Peracchi. 1987. Quirópteros da região de Manaus, Amazonas, Brasil (Mammalia, Chiroptera). Boletim do Museu Paraense Emílio Goeldi, Série Zoologia 3: 161-182.

Emmons, L.H., and F. Feer. 1997. Neotropical rainforest mammals: a field guide, 2nd ed. Chicago: University of Chicago Press.

Emmons, L.H., L. Luna W., and M. Romo R. 2001. Mammals of the northern Vilcabamba mountain range, Peru. In L.E. Alonso, A. Alonso, T.S. Schulenberg, and F. Dallmeier (editors), Biological and social assessments of the Cordillera de Vilcabamba, Peru. RAP Working Papers 12 \& SI/MAB Series 6: 105-109, 255-257. Washington, D.C.: Conservation International.

Foster, R.B., J.B. Arce, and T.S. Wachter. 1986. Dispersal and the sequential plant communities in Amazonian Peru floodplain. In A. Estrada and T.H. Fleming (editors), Frugivores and seed dispersal: 357-370. Dordrecht: Dr. W. Junk Publishers.

Garbino, G.S.T., C.C. de Aquino, and C.C. Aires. 2012. First record for the state of Rondônia and revised distribution map of Chiroderma trinitatum Goodwin, 1958 (Mammalia: Chiroptera: Phyllostomidae) in Brazil. Check List 8: 254-257.

Gardner, A.L. 1973. The systematics of the genus Didelphis (Marsupialia: Didelphidae) in North and Middle America. Special Publications, Texas Tech University Museum 4: 1-81.

Gardner, A.L. 1976. The distributional status of some Peruvian mammals. Occasional Papers of the Museum of Zoology, Louisiana State University 48: 1-18.

Gardner, A.L. 2008a ("2007"). Mammals of South America, vol. 1: Marsupials, Xenarthrans, Shrews, and Bats. Mammals of South America: 1-690. 
Gardner, A.L. 2008b (“2007”). Family Phyllostomidae Gray, 1825. In A.L. Gardner (editor), Mammals of South America, vol. 1: Marsupials, xenarthrans, shrews, and bats: 207-208. Chicago: University of Chicago Press.

Gardner, A.L. 2008c ("2007”). Genus Chiroderma W. Peters, 1860. In A.L. Gardner (editor), Mammals of South America, vol. 1: Marsupials, xenarthrans, shrews, and bats: 321-326. Chicago: University of Chicago Press.

Gardner, A.L. 2008d (“2007”). Genus Platyrrhinus Saussure, 1860. In A.L. Gardner (editor), Mammals of South America, vol. 1: Marsupials, xenarthrans, shrews, and bats: 329-342. Chicago: University of Chicago Press.

Gardner, A.L. 2008e (“2007”). Tribe Sturnirini. In A.L. Gardner (editor), Mammals of South America, vol. 1: Marsupials, xenarthrans, shrews, and bats: 363376. Chicago: University of Chicago Press.

Gardner, A.L., and D.C. Carter. 1972. A review of the Peruvian species of Vampyrops (Chiroptera: Phyllostomatidae). Journal of Mammalogy, 53: 72-82.

Gardner, A.L., and G.K. Creighton. 2008 (“2007”). Genus Marmosops Matschie, 1916. In A.L. Gardner (editor), Mammals of South America, vol. 1: Marsupials, xenarthrans, shrews, and bats: 61-74. Chicago: University of Chicago Press.

Genoways, H.H., and S.L. Williams. 1979. Records of bats (Mammalia: Chiroptera) from Suriname. Annals of Carnegie Museum 48: 323-335.

Geoffoy St.-Hilaire, É. 1810. Sur les phyllostomes et les mégadermes, deux genres de la famille des chauve-souris. Annales du Muséum d'Histoire Naturelle, 15: 157-198, pls. 159-112.

Gonçalves, P.R., P. Teta, and C.R. Bonvicino. 2015. Genus Holochilus Brandt, 1835. In J.L. Patton, U.F.J. Pardiñas, and G. D'Elía (editors), Mammals of South America, vol. 2: Rodents: 325-335. Chicago: University of Chicago Press.

Gonzales Inca, C.A., and R. Llanos López. 2015. Reporte técnico: evaluación de los efectos de la deforestación sobre la hidrología y flujo lateral del carbono orgánico del suelo en la cuenca del Alto Mayo, Perú. CI-Peru, Moyobamba, San Martín, Peru.

Goodwin, G.G. 1958. Three new bats from Trinidad. American Museum Novitates 1877: 1-6.

Goodwin, G.G. 1963. American bats of the genus Vampyressa with the description of a new species. American Museum Novitates 2125: 1-24.

Goodwin, G.G., and A.M. Greenhall. 1961. A review of the bats of Trinidad and Tobago: descriptions, rabies infection, and ecology. Bulletin of the American Museum of Natural History 122 (3): 187-302.

Goodwin, G.G., and A.M. Greenhall. 1962. Two new bats from Trinidad, with comments on the status of the genus Mesophylla. American Museum Novitates 2080: 1-18.

Gorchov, D., F. Cornejo, C. Ascorra, and M. Jaramillo. 1995. Dietary overlap between frugivorous birds and bats in the Peruvian Amazon. Oikos 74: 235-250.

Gray, J.E. 1842. Descriptions of some new genera and 50 unrecorded species of Mammalia. Annals and Magazine of Natural History (1) 10: 255-267.

Gray, J.E. 1849. Observations on some Brazilian bats with the description of a new genus. Proceedings of the Zoological Society of London 1848: 57-58. [published 30 January 1849]

Greenhall, A.M., G. Joermann, and U. Schmidt. 1983. Desmodus rotundus. Mammalian Species 202: 1-6.

Greenhall, A.M., U. Schmidt, and G. Joermann. 1984. Diphylla ecaudata. Mammalian Species 227: 1-3.

Gregorin, R., and A.D. Ditchfield. 2005. New genus and species of nectar-feeding bat in the tribe Lonchophyllini (Phyllostomidae: Glossophaginae) from northeastern Brazil. Journal of Mammalogy 86: 403-414.

Gregorin, R., E. Gonçalves, B.K. Lim, and M.D. Engstrom. 2006. New species of disk-winged bat Thyroptera and range extension for $T$. discifera. Journal of Mammalogy 87: 238-246.

Griffiths, T.A., and A.L. Gardner. 2008a (“2007”). Subfamily Glossophaginae Bonaparte, 1845. In A.L. Gardner (editor), Mammals of South America, vol. 1: Marsupials, xenarthrans, shrews, and bats: 224244. Chicago: University of Chicago Press.

Griffiths, T.A., and A.L. Gardner. 2008b (“2007”). Subfamily Lonchophyllinae Griffiths, 1982. In A.L. Gardner (editor), Mammals of South America, vol. 1: Marsupials, xenarthrans, shrews, and bats: 244255. Chicago: University of Chicago Press.

Handley, C.O., Jr. 1960. Descriptions of new bats from Panama. Proceedings of the United States National Museum 113: 459-479.

Handley, C.O., Jr. 1976. Mammals of the Smithsonian Venezuelan Project. Brigham Young University Science Bulletin, Biological Series, 20: 1-91.

Handley, C.O., Jr. 1984. New species of mammals from northern South America: a long-tongued bat, genus Anoura Gray. Proceedings of the Biological Society of Washington 97: 513-521.

Handley, C.O., Jr. 1987. New species of mammals from northern South America: fruit-eating bats, genus 
Artibeus Leach. Fieldiana Zoology, New Series 39: $163-172$.

Haynes, M.A., and T.E. Lee, Jr. 2004. Artibeus obscurus. Mammalian Species 752: 1-5.

Hernández-Canchola, G., and L. León-Paniagua. 2017. Genetic and ecological processes promoting early diversification in the lowland Mesoamerican bat Sturnira parvidens (Chiroptera: Phyllostomidae). Molecular Phylogenetics and Evolution 114: 334-345.

Hershkovitz, P. 1944. A systematic review of the Neotropical water rats of the genus Nectomys (Cricetinae). Miscellaneous Publications, Museum of Zoology, University of Michigan 58: 1-101.

Hice, C.L., and P.M. Velazco. 2012. The non-volant mammals of the Reserva Nacional Allpahuayo-Mishana, Loreto, Peru. Special Publications, Texas Tech University Museum 60: 1-135.

Hice, C.L., P.M. Velazco, and M. Willig. 2004. Bats of the Reserva Nacional Allpahuayo-Mishana, northeastern Peru, with notes on community structure. Acta Chiropterologica 6: 319-334.

Hill, J.E. 1964. Notes on bats from British Guiana, with the description of a new genus and species of Phyllostomidae. Mammalia 28: 553-572.

Hill, J.E. 1980. A note on Lonchophylla (Chiroptera: Phyllostomatidae) from Ecuador and Peru, with the description of a new species. Bulletin of the British Museum (Natural History) Zoology 38: 233-236.

Hollis, L. 2005. Artibeus planirostris. Mammalian Species 775: 1-6.

Hood, C.S., and A.L. Gardner. 2008 (“2007”). Family Emballonuridae Gervais, 1856. In A.L. Gardner (editor), Mammals of South America, vol. 1: Marsupials, xenarthrans, shrews, and bats: 188-207. Chicago: University of Chicago Press.

Hoofer, S.R., S. Solari, P.A. Larsen, R.D. Bradley, and R.J. Baker. 2008. Phylogenetics of the fruit-eating bats (Phyllostomidae: Artibeina) inferred from mitochondrial DNA sequences. Occasional Papers of the Museum, Texas Tech University 277: 1-16.

Hurtado, N., and G. D'Elía. 2019. Taxonomy of the longtailed mouse Oligoryzomys destructor (Sigmodontinae: Oryzomyini) with the designation of neotypes for Hesperomys destructor Tschudi, 1844 and Hesperomys melanostoma Tschudi, 1844. Journal of Zoological Systematics and Evolutionary Research 57: 127-144.

Hurtado, N., and V. Pacheco. 2017. Revision of Neacomys spinosus (Thomas, 1882) (Rodentia: Cricetidae) with emphasis on Peruvian populations and the description of a new species. Zootaxa 4242: 401-440.
Husson, A.M. 1962. The bats of Suriname. Zoölogische Verhandelingen (Rijksmuseum van Natuurlijke Historie, Leiden) 58: 1-282.

Husson, A.M. 1978. The mammals of Suriname. Zoölogische Monographieën van het Rijksmuseum van Natuurlijke Historie (Leiden) 2: 569 pp. + 151 pls.

Jarrín-V, P., and E.L. Clare. 2013. Systematics of Sturnira (Chiroptera: Phyllostomidae) in Ecuador, with comments on species boundaries. Zootaxa 3630: 165-183.

Jarrín-V, P., and T.H. Kunz. 2011. A new species of Sturnira (Chiroptera: Phyllostomidae) from the Choco forest of Ecuador. Zootaxa 2755: 1-35.

Jiménez, C.F., V. Pacheco, and D. Vivas. 2013. An introduction to the systematics of Akodon orophilus Osgood, 1913 (Rodentia: Cricetidae) with the description of a new species. Zootaxa 3669: 223-242.

Jones, J.K., Jr., and C.S. Hood. 1993. Synopsis of South American bats of the family Emballonuridae. Occasional Papers of the Museum of Texas Tech University 155: 1-32.

Jones, J.K., Jr., and C.J. Phillips. 1976. Bats of the genus Sturnira in the Lesser Antilles. Occasional Papers of the Museum of Texas Tech University 40: 1-16.

Koepcke, J., and R. Kraft. 1984. Cranial and external characters of the larger fruit bats of the genus Artibeus from Amazonian Peru (Chiroptera, Phyllostomidae). Spixiana 7: 75-84.

Koopman, K.F. 1993. Order Chiroptera. Mammal species of the world: a taxonomic and geographic reference, 2nd ed.: 137-241. Washington: Smithsonian Institution Press.

Koopman, K.F. 1994. Chiroptera: systematics. Handbuch der Zoologie VIII (Mammalia) 60: $1-217$.

Kwiecinski, G.G., et al. 2018. Bats of Saint Vincent, Lesser Antilles. Special Publication of the Museum of Texas Tech University 68: 1-68.

Kwon, M., and A.L. Gardner. 2008 (“2007”). Subfamily Desmodontinae J.A. Wagner, 1840. In A.L. Gardner (editor), Mammals of South America, vol. 1: Marsupials, xenarthrans, shrews, and bats: 218-224. Chicago: University of Chicago Press.

Lareschi, M., and P.M. Velazco. 2013. Laelapinae mites (Acari, Parasitiformes, Laelapidae) parasitic of sigmodontinae rodents from northern Peru, with the description of a new species from Akodon aerosus (Rodentia, Cricetidae, Sigmodontinae). Journal of Parasitology 99: 189-193.

Larsen, P.A., M.R. Marchán-Rivadeneira, and R.J. Baker. 2013. Speciation dynamics of the fruit-eating 
bats (genus Artibeus): with evidence of ecological divergence in Central American populations. In R.A. Adams and S.C. Pedersen (editors), Bat evolution, ecology, and conservation: 315-339. New York: Springer.

Larsen, R.J., et al. 2012. Genetic diversity of Neotropical Myotis (Chiroptera: Vespertilionidae) with an emphasis on South American species. PLoS ONE 7: e46578.

LaVal, R.K. 1973. A revision of the Neotropical bats of the genus Myotis. Bulletin of the Natural History Museum of Los Angeles County 15: 1-54.

Lemos, B., and R. Cerqueira. 2002. Morphological differentiation in the white-eared opossum group (Didelphidae: Didelphis). Journal of Mammalogy 83: 354-369.

Leo, M. 1995. The importance of Tropical Montane Cloud Forest for preserving vertebrate endemism in Peru: the Río Abiseo National Park as a case study. In L.S. Hamilton, J.O. Juvik, and F.N. Scatena (editors), Tropical Montane Cloud Forests. New York: Springer.

Leo, M., and M. Romo R. 1992. Distribución altitudinal de roedores sigmodontinos (Cricetidae) en el Parque Nacional Río Abiseo, San Martín, Peru. Memorias del Museo de Historia Natural, UNMSM 21: 105-118.

Lichtenstein, H. 1823. Verzeichniss der Doubletten des Zoologischen Museums der Königl. Universität zu Berlin nebst Beschreibung vieler bisher unbekannter Arten von Säugethieren, Vögeln, Amphibien und Fischen. Berlin: Commission bei T. Trautwein.

Lim, B.K. 1997. Morphometric differentiation and species status of the allopatric fruit-eating bats Artibeus jamaicensis and A. planirostris in Venezuela. Studies on Neotropical Fauna and Environment 32: 65-71.

Lim, B.K., and D.E. Wilson. 1993. Taxonomic status of Artibeus amplus (Chiroptera: Phyllostomidae) in northern South America. Journal of Mammalogy 74: 763-768.

Lim, B.K., W.A. Pedro, and F.C. Passos. 2003. Differentiation and species status of the Neotropical yelloweared bats Vampyressa pusilla and V. thyone (Phyllostomidae) with a molecular phylogeny and review of the genus. Acta Chiropterologica 5: 15-29.

Lim, B.K., et al. 2005. Results of the ALCOA Foundation-Suriname expeditions. XIV. Mammals of Brownsberg Nature Park, Suriname. Annals of Carnegie Museum 74: 225-274.

Lim, B.K., M.D. Engstrom, J.C. Patton, and J.W. Bickham. 2008. Systematic review of small fruit-eating bats (Artibeus) from the Guianas, and a re-evaluation of A. glaucus bogotensis. Acta Chiropterologica 10: 243-256.

Lim, B.K., et al. 2010. A new species of Peropteryx (Chiroptera: Emballonuridae) from Western Amazonia with comments on phylogenetic relationships within the genus. American Museum Novitates 3686: 1-20.

Linares, O.J. 1998. Mamíferos de Venezuela. Caracas: Sociedad Conservacionista Audubon de Venezuela.

Lobova, T.A., and S.A. Mori. 2004. Epizoochorous dispersal by bats in French Guiana. Journal of Tropical Ecology 20: 581-582.

Lobova, T.A., S.A. Mori, F. Blanchard, H. Peckham, and P. Charles-Dominique. 2003. Cecropia as a food resource for bats in French Guiana and the significance of fruit structure in seed dispersal and longevity. American Journal of Botany 90: 388-403.

Lobova, T.A., C.K. Geiselman, and S.A. Mori. 2009. Seed dispersal by bats in the Neotropics. New York: New York Botanical Garden Press.

López-González, C., S.J. Presely, R.D. Owen, and M.R. Willig. 2001. Taxonomic status of Myotis (Chiroptera: Vespertilionidae) in Paraguay. Journal of Mammalogy 82: 138-160.

Maas, P.J.M., et al. 1992. Rollinia. Flora Neotropica 57: $1-188$.

Maestri, R., and B.D. Patterson. 2016. Patterns of species richness and turnover for the South American rodent fauna. PLoS ONE 11: e0151895.

Mantilla-Meluk, H. 2014. Defining species and species boundaries in Uroderma (Chiroptera: Phyllostomidae) with a description of a new species. Occasional Papers of the Museum of Texas Tech University 325: 1-25.

Mantilla-Meluk, H., and R.J. Baker. 2006. Systematics of small Anoura (Chiroptera: Phyllostomidae) from Colombia, with description of a new species. Occasional Papers of the Museum of Texas Tech University $261: 1-18$.

Mantilla-Meluk, H., and R.J. Baker. 2010. New species of Anoura (Chiroptera: Phyllostomidae) from Colombia, with systematic remarks and notes on the distribution of the A. geoffroyi complex. Occasional Papers of the Museum of Texas Tech University 292: 1-24.

Mantilla-Meluk, H., and J. Muñoz-Garay. 2014. Biogeography and taxonomic status of Myotis keaysi pilosatibialis LaVal 1973 (Chiroptera: Vespertilionidae). Zootaxa 3793: 60-70.

Mantilla-Meluk, H., H.E. Ramírez-Chaves, J.A. Parlos, and R.J. Baker. 2010. Geographic range extensions 
and taxonomic notes on bats of the genus Lonchophylla (Phyllostomidae) from Colombia. Mastozoologia Neotropical 17: 295-303.

Marchan-Rivadeneira, M.R., P.A. Larsen, C.J. Phillips, R.E. Strauss, and R.J. Baker. 2012. On the association between environmental gradients and skull size variation in the great fruit-eating bat, Artibeus lituratus (Chiroptera: Phyllostomidae). Biological Journal of the Linnean Society 105: 623-634.

Marinkelle, C.J., and A. Cadena. 1971. Remarks on Sturnira tildae in Colombia. Journal of Mammalogy 52: 235-237.

Marques-Aguiar, S.A. 1985. Novos registros de morcegos do Parque Nacional de Amazonia (Tapajós), com observações do período de atividade noturna e reprodução. Boletim do Museu Paraense Emílio Goeldi, Série Zoologia 2: 71-83.

Marques-Aguiar, S.A. 1994. A systematic review of the large species of Artibeus Leach, 1821 (Mammalia: Chiroptera) with some phylogenetic inferences. Boletim do Museu Paraense Emílio Goeldi, Série Zoologia 10: 3-83.

Marques-Aguiar, S.A. 2008 (“2007”). Genus Artibeus Leach, 1821. In A.L. Gardner (editor), Mammals of South America, vol. 1: Marsupials, xenarthrans, shrews, and bats: 301-321. Chicago: University of Chicago Press.

Martínez-Arias, V.M., S. Solari, and J.F. Diaz-N. 2010. Re-evaluation of a Colombian record of Sturnira thomasi de la Torre and Schwartz, 1966 (Phyllostomidae: Stenodermatinae). Chiroptera Neotropical 16: 604-610.

Matthias, M.A., et al. 2005. Diversity of bat-associated Leptospira in the Peruvian Amazon inferred by Bayesian phylogenetic analysis of $16 \mathrm{~S}$ ribosomal DNA sequences. American Journal of Tropical Medicine and Hygiene 73: 964-974.

McLellan, L.J., and K.F. Koopman. 2008 (“2007”). Subfamily Carolliinae Miller, 1924. In A.L. Gardner (editor), Mammals of South America, vol. 1: Marsupials, xenarthrans, shrews, and bats: 208-216. Chicago: University of Chicago Press.

Miller, G.S., Jr. 1913. Revision of the bats of the genus Glossophaga. Proceedings of the United States National Museum 46: 413-429.

Molinari, J. 1994. A new species of Anoura (Mammalia Chiroptera Phyllostomidae) from the Andes of northern South America. Tropical Zoology 7: 73-86.

Molinari, J., et al. 2017. A new polytypic species of yellow-shouldered bats, genus Sturnira (Mammalia:
Chiroptera: Phyllostomidae), from the Andean and coastal mountain systems of Venezuela and Colombia. Zootaxa 4243: 75-96.

Moratelli, R., and J.A. de Oliveira. 2011. Morphometric and morphological variation in South American populations of Myotis albescens (Chiroptera: Vespertilionidae). Zoologia 28: 789-802.

Moratelli, R., and D.E. Wilson. 2011. The identity of Myotis punensis (Chiroptera: Vespertilionidae). Zoologia 28: 115-121.

Moratelli, R., and D.E. Wilson. 2014. A second record of Myotis diminutus (Chiroptera: Vespertilionidae): its bearing on the taxonomy of the species and discrimination from $M$. nigricans. Proceedings of the Biological Society of Washington 127: 533-542.

Moratelli, R., A.L. Peracchi, and J.A. de Oliveira. 2011a. Morphometric and morphological variation in Myotis simus Thomas (Chiroptera, Vespertilionidae), with an appraisal of the identity of Myotis guaycuru Proença based on the analysis of the type material. Zootaxa 2985: 41-54.

Moratelli, R., A.L. Peracchi, D. Dias, and J.A. de Oliveira. 2011b. Geographic variation in South American populations of Myotis nigricans (Chiroptera, Vespertilionidae), with the description of two new species. Mammalian Biology 76: 592-607.

Moratelli, R., A.L. Gardner, J.A. de Oliveira, and D.E. Wilson. 2013. Review of Myotis (Chiroptera, Vespertilionidae) from northern South America, including description of a new species. American Museum Novitates 3780: 1-36.

Musser, G.G., M.D. Carleton, E.M. Brothers, and A.L. Gardner. 1998. Systematic studies of oryzomyine rodents (Muridae, Sigmodontinae): diagnoses and distributions of species formerly assigned to Oryzomys "capito." Bulletin of the American Museum of Natural History 236: 1-376.

Myers, P. 1990. A review of the Boliviensis group of Akodon (Muridae: Sigmodontinae): with emphasis on Peru and Bolivia. Miscellaneous Publications, Museum of Zoology, University of Michigan 177: 1-104.

Nava, S., P.M. Velazco, and A. Guglielmone. 2010. First record of Amblyomma longirostre (Koch, 1844) (Acari: Ixodidae) from Peru, with a review of this tick's host relationships. Systematic and Applied Acarology 15: 21-30.

Nogueira, M.R., I.P. Lima, A.L. Peracchi, and N.B. Simmons. 2012. New genus and species of nectar-feeding bat from the Atlantic Forest of southeastern Brazil (Chiroptera: Phyllostomidae: Glossophaginae). American Museum Novitates 3747: 1-30. 
Novaes, R.L.M., R.F. Souza, and R. Moratelli. 2017. Myotis riparius (Chiroptera: Vespertilionidae). Mammalian Species 946: 51-56.

Olds, N., and S. Anderson. 1987. Notes on Bolivian mammals. 2. Taxonomy and distribution of rice rats of the subgenus Oligoryzomys. Fieldiana Zoology, New Series 39: 261-281.

Ortega, J., et al. 2015. Artibeus glaucus (Chiroptera: Phyllostomidae). Mammalian Species 928: 107-111.

Osgood, W.H. 1913. New Peruvian mammals. Field Museum of Natural History, Zoological Series 10: 93-100.

Osgood, W.H. 1914. Mammals of an expedition across northern Peru. Field Museum of Natural History, Zoological Series 10: 143-185.

Pacheco, V., R. Cadenillas, E. Salas, C. Tello, and H. Zeballos. 2009. Diversidad y endemismo de los mamíferos del Perú. Revista Peruana de Biologia 16: $5-32$.

Pacheco, V., E. Salas, C. Barriga, and E. Rengifo. 2013. Small mammal diversity in disturbed and undisturbed montane forest in the area of influence of the PERU LNG Pipeline, Apurímac River watershed, Ayacucho, Peru. In A. Alonso, F. Dallmeier, and G.P. Servat (editors), Monitoring Biodiversity: lessons from a trans-Andean megaproject: 90-100. Washington, D.C.: Smithsonian Institution Scholarly Press.

Pacheco, V., P. Sánchez-Vendizú, and S. Solari. 2018. A new species of Anoura Gray, 1838 (Chiroptera: Phyllostomidae) from Peru, with taxonomic and biogeographic comments on species of the Anoura caudifer complex. Acta Chiropterologica 20: 31-50.

Pardiñas, U.F.J. 2017a. Tschudi's pygmy rice rat Oligoryzomys destructor. In D.E. Wilson, T.E. Lacher, Jr., and R.A. Mittermeier (editors), Handbook of the mammals of the world: 432. Barcelona: Lynx Edicions.

Pardiñas, U.F.J. 2017b. Small-eared pygmy rice rat Oligoryzomys microtis. In D.E. Wilson, T.E. Lacher, Jr., and R.A. Mittermeier (editors), Handbook of the mammals of the world: 433. Barcelona: Lynx Edicions.

Pardiñas, U.F.J., and E. Cuéllar Soto. 2017. Yungas grass mouse Akodon aerosus. In D.E. Wilson, T.E. Lacher, Jr., and R.A. Mittermeier (editors), Handbook of the mammals of the world: 473. Barcelona: Lynx Edicions.

Pardiñas, U.F.J., et al. 2015. Genus Akodon Meyen, 1833. In J.L. Patton, U.F.J. Pardiñas, and G. D’Elía (editors), Mammals of South America, vol. 2: Rodents: 144204. Chicago: University of Chicago Press.
Pardiñas, U.F.J., et al. 2017. Family Cricetidae (True hamsters, voles, lemmings and New World rats and mice). In D.E. Wilson, T.E. Lacher, Jr., and R.A. Mittermeier (editors), Handbook of the mammals of the world: 204-279. Barcelona: Lynx Edicions.

Parks Watch. 2003. Protected area profile - Peru Alto Mayo protected forest. Online resource (http://w. parkswatch.org/parkprofiles/pdf/ampf_eng.pdf), accessed October 5, 2018.

Patten, D.R. 1971. A review of the large species of Artibeus (Chiroptera: Phyllostomidae) from western South America, Ph.D. dissertation, Texas A\&M University, College Station, $194 \mathrm{pp}$.

Patterson, B.D., S. Solari, and P.M. Velazco. 2012. The role of the Andes in the diversification and biogeography of Neotropical mammals. In B.D. Patterson and L.P. Costa (editors), Bones, clones, and biomes: the history and geography of Recent Neotropical mammals: 351-378. Chicago: University of Chicago Press.

Patton, J.L., M.N.F. da Silva, and J.R. Malcolm. 2000. Mammals of the Rio Juruá and the evolutionary and ecological diversification of Amazonia. Bulletin of the American Museum of Natural History 244: 1-306.

Pedersen, S.C., et al. 2018. Bats of Saint Lucia, Lesser Antilles. Special Publications, Texas Tech University Museum 69: 1-61.

Pelzeln, A., von. 1883. Brasilische Säugethiere. Resultate von Johann Natterer's Reisen in den Jahren 1817 bis 1835. Verhandlungen der Kaiserlich-Königlichen Zoologisch-Botanischen Gesellschaft in Wien 33 (Suppl.): 1-140.

Percequillo, A.R. 2015a. Genus Euryoryzomys Weksler, Percequillo, and Voss, 2006. In J.L. Patton, U.F.J. Pardiñas, and G. D'Elía (editors), Mammals of South America, vol. 2: Rodents: 312-321. Chicago: University of Chicago Press.

Percequillo, A.R. 2015b. Genus Hylaeamys Weksler, Percequillo, and Voss, 2006. In J.L. Patton, U.F.J. Pardiñas, and G. D'Elía (editors), Mammals of South America, vol. 2: Rodents: 335-346. Chicago: University of Chicago Press.

Phillips, C.J. 1971. The dentition of glossophagine bats: development, morphological chractreristics, variation, pathology, and evolution. University of Kansas Museum of Natural History Miscellaneous Publications 64: 1-138.

Pine, R.H. 1972. The bats of the genus Carollia. Texas Agricultural Experiment Station, Technical Monograph 8: 1-125. 
Pine, R.H. 1993. A new species of Thyroptera Spix (Mammalia: Chiroptera: Thyropteridae) from the Amazon basin of northeastern Perú. Mammalia 57: 213-225.

Prado, J.R., E.A. Chiquito, and A.R. Percequillo. 2017a. McConnell's rice rat Euryoryzomys macconnelli. In D.E. Wilson, T.E. Lacher, Jr., and R.A. Mittermeier (editors), Handbook of the mammals of the world: 423. Barcelona: Lynx Edicions.

Prado, J.R., E.A. Chiquito, and A.R. Percequillo. 2017b. Amazonian marsh rat Holochilus sciureus. In D.E. Wilson, T.E. Lacher, Jr., and R.A. Mittermeier (editors), Handbook of the mammals of the world: 443-444. Barcelona: Lynx Edicions.

Ramírez-Chaves, H.E., A.F. Suárez-Castro, and J.F. González-Maya. 2016. Cambios recientes a la lista de los mamíferos de Colombia. Mammalogy Notes 3: 1-9.

Redondo, R.A.F., L.P.S. Brina, R.F. Silva, A.D. Ditchfield, and F.R. Santos. 2008. Molecular systematics of the genus Artibeus (Chiroptera: Phyllostomidae). Molecular Phylogenetics and Evolution 49: 44-58.

Reid, F. 2009. A field guide to the mammals of Central America and southeast Mexico. New York: Oxford University Press.

Reiss, N.R., and W.Y. Mok. 1979. Wangiella dermatitidis isolated from bats in Manaus Brazil. Sabouraudia 17: 213-218.

Reyes-Amaya, N., J. Lozáno-Flórez, D. Flores, and S. Solari. 2016. Distribution of the spix's disk-winged bat, Thyroptera tricolor Spix, 1823 (Chiroptera: Thyropteridae) in Colombia, with first records for the middle Magdalena Valley. Mastozoologia Neotropical 23: $127-137$.

Rinehart, J.B., and T.H. Kunz. 2006. Rhinophylla pumilio. Mammalian Species 791: 1-5.

Rocha, P.A., M.V. Brandão, G. Garbino, S. T., I.N. Cunha, and C.C. Aires. 2016. First record of Salvin's big-eyed bat Chiroderma salvini Dobson, 1878 for Brazil. Mammalia 80: 573-578.

Rocha, P.A., et al. 2018. First record of Dermanura anderseni (Chiroptera, Phyllostomidae) for the Atlantic Forest. Mammalia 82: 388-392.

Ruelas, D., and E. López. 2018. Análisis morfogeométrico de las especies peruanas de Carollia (Chiroptera: Phyllostomidae). Mastozoologia Neotropical 25: 419-438.

Ruelas, D., and U.F.J. Pardiñas. 2017. White-bellied arboreal rice rat Oecomys bicolor. In D.E. Wilson, T.E. Lacher, Jr., and R.A. Mittermeier (editors), Handbook of the mammals of the world: 419 . Barcelona: Lynx Edicions.
Rui, A.M., M.E. Fabián, and J.O. Menegheti. 1999. Distribuição geográfica e análise morfológica de Artibeus lituratus Olfers e de Artibeus fimbriatus Gray (Chiroptera, Phyllostomidae) no Rio Grande do Sul, Brasil. Revista Brasileira de Zoologia 16: 447-460.

Sanborn, C.C. 1937. American bats of the subfamily Emballonurinae. Field Museum of Natural History, Zoological Series 20: 321-354.

Sánchez-Hernández, C., M.L. Romero-Almaraz, and G.D. Schnell. 2005. New species of Sturnira (Chiroptera: Phyllostomidae) from northern South America. Journal of Mammalogy 86: 866-872.

Schinz, H.R. 1845. Systematisches Verzeichniss aller bis jetzt bekannten Säugethiere oder Synopsis Mammalium nach dem Cuvier'schen System. Solothurn: Jent und Gassmann.

SENAMHI. 2009. Escenarios climáticos en la cuenca del Río Mayo para el año 2030. Segunda Comunicación Nacional de Cambio Climático. Lima: Servicio Nacional de Meteorología e Hidrología, Ministerio del Ambiente.

Shanee, S., N. Shanee, and A.M. Maldonado. 2007a. Conservation assessment and planning for the yellow-tailed woolly monkey (Oreonax flavicauda) in Peru. Wildlife Biology in Practice 3: 73-82.

Shanee, S., N. Shanee, and A.M. Maldonado. 2007b. Distribution and conservation status of the yellowtailed woolly monkey (Oreonax flavicauda, Humboldt 1812) in Amazonas and San Martín, Peru. Neotropical Primates 14: 115-119.

Simmons, N.B. 2005. Order Chiroptera. In D.E. Wilson and D.M. Reeder (editors), Mammal species of the world, a taxonomic and geographic reference, 3rd ed.: 312-529. Baltimore: Johns Hopkins University Press.

Simmons, N.B., and R.S. Voss. 1998. The mammals of Paracou, French Guiana: a Neotropical lowland rainforest fauna. Part 1. Bats. Bulletin of the American Museum of Natural History 237: 1-219.

Solari, S., and R.J. Baker. 2006. Mitochondrial DNA sequence, karyotypic, and morphological variation in the Carollia castanea species complex (Chiroptera: Phyllostomidae) with description of a new species. Occasional Papers of the Museum of Texas Tech University 254: 1-16.

Solari, S., V. Pacheco, and E. Vivar. 1999. New distribution records of Peruvian bats. Revista Peruana de Biologia 2: 152-159.

Solari, S., R.A. Van Den Bussche, S.R. Hoofer, and B.D. Patterson. 2004. Geographic distribution, ecology, 
and phylogenetic affinities of Thyroptera lavali Pine 1993. Acta Chiropterologica 6: 293-302.

Solari, S., V. Pacheco, L. Luna, P.M. Velazco, and B. Patterson. 2006. Mammals of the Manu Biosphere Reserve. Fieldiana Zoology, new series 110: 13-22.

Solari, S., et al. 2009. Operational criteria for genetically defined species: analysis of the diversification of the small fruit-eating bats, Dermanura (Phyllosomidae: Stenodermatinae). Acta Chiropterologica 11: 279288.

Starrett, A., and R. Casebeer. 1968. Records of bats from Costa Rica. Registros de murciélagos de Costa Rica. Contributions in Science (Los Angeles) 148: $1-21$.

Suárez-Villota, E.Y., A.P. Carmignotto, M.V. Brandão, A.R. Percequillo, and M.J.d.J. Silva. 2018. Systematics of the genus Oecomys (Sigmodontinae: Oryzomyini): molecular phylogenetic, cytogenetic and morphological approaches reveal cryptic species. Zoological Journal of the Linnean Society 184: 182210.

Swanepoel, P., and H.H. Genoways. 1979. Morphometrics. In R.J. Baker, J.K. Jones, Jr., and D.C. Carter (editors), Biology of bats of the New World family Phyllostomatidae, Part III: 1-441. Special Publications, Texas Tech University Museum 16.

Taddei, V.A., and B.K. Lim. 2010. A new species of Chiroderma (Chiroptera, Phyllostomidae) from Northeastern Brazil. Brazilian Journal of Biology, 70: 381-386.

Tamsitt, J.R., A. Cadena, and E. Villarraga. 1986. Records of bats (Sturnira magna and Sturnira aratathomasi) from Colombia. Journal of Mammalogy 67: 754-757.

Tavares, V.d.C., A.L. Gardner, H.E. Ramírez-Chaves, and P.M. Velazco. 2014. Systematics of Vampyressa melissa Thomas, 1926 (Chiroptera: Phyllostomidae), with descriptions of two new species of Vampyressa. American Museum Novitates 3813: 1-27.

Tello, C., G. Streicker Daniel, J. Gomez, and P.M. Velazco. 2014. New records of pigmentation disorders in molossid and phyllostomid (Chiroptera) bats from Peru. Mammalia 78: 191-197.

Thomas, O. 1924. New Callicebus, Conepatus, and Oecomys from Peru. Annals and Magazine of Natural History (Ser. 9) 14: 286-288.

Thomas, O. 1927. The Godman-Thomas expedition to Peru-V. On mammals collected by Mr. R. W. Hendee in the province of San Martín, N. Peru, mostly at Yurac Yacu. Annals and Magazine of Natural History (Ser. 9) 19: 361-373.
Tuttle, M.D. 1970. Distribution and zoogeography of Peruvian bats: with comments on natural history. University of Kansas Science Bulletin 49: 45-86.

Velazco, P.M. 2005. Morphological phylogeny of the bat genus Platyrrhinus Saussure, 1860 (Chiroptera: Phyllostomidae) with the description of four new species. Fieldiana Zoology, New Series 105: 1-53.

Velazco, P.M. 2013. On the phylogenetic position of Carollia manu Pacheco et al., 2004 (Chiroptera: Phyllostomidae: Carolliinae). Zootaxa 3718: 267276.

Velazco, P.M., and R. Cadenillas. 2011. On the identity of Lophostoma silvicolum occidentalis (Davis \& Carter, 1978) (Chiroptera: Phyllostomidae). Zootaxa 2962: 1-20.

Velazco, P.M., and A.L. Gardner. 2009. A new species of Platyrrhinus (Chiroptera: Phyllostomidae) from western Colombia and Ecuador, with emended diagnoses of $P$. aquilus, $P$. dorsalis, and $P$. umbratus. Proceedings of the Biological Society of Washington 122: 249-281.

Velazco, P.M., and A.L. Gardner. 2012. A new species of Lophostoma d'Orbigny, 1836 (Chiroptera: Phyllostomidae) from Panama. Journal of Mammalogy 93: 605-614.

Velazco, P.M., and B.K. Lim. 2014. A new species of broad-nosed bat Platyrrhinus Saussure, 1860 (Chiroptera: Phyllostomidae) from the Guianan Shield. Zootaxa 3796: 175-193.

Velazco, P.M., and B.D. Patterson. 2013. Diversification of the yellow-shouldered bats, genus Sturnira (Chiroptera, Phyllostomidae), in the New World tropics. Molecular Phylogenetics and Evolution 68: 683-698.

Velazco, P.M., and B.D. Patterson. 2014. Two new species of yellow-shouldered bats, genus Sturnira Gray, 1842 (Chiroptera, Phyllostomidae) from Costa Rica, Panama and western Ecuador. ZooKeys 402: 43-66.

Velazco, P.M., A.L. Gardner, and B.D. Patterson. 2010. Systematics of the Platyrrhinus helleri species complex (Chiroptera: Phyllostomidae), with descriptions of two new species. Zoological Journal of the Linnean Society 159: 785-812.

Velazco, P.M., R. Gregorin, R.S. Voss, and N.B. Simmons. 2014. Extraordinary local diversity of diskwinged bats (Thyropteridae: Thyroptera) in northeastern Peru, with the description of a new species and comments on roosting behavior. American Museum Novitates 3795: 1-28.

Velazco, P.M., J.A. Soto-Centeno, D.W. Fleck, R.S. Voss, and N.B. Simmons. 2017. A new species of nectarfeeding bat of the genus Hsunycteris (Phyllostomi- 
dae: Lonchophyllinae) from northeastern Peru. American Museum Novitates 3881: 1-26.

Vermeer, J., J.C. Tello-Alvarado, S. Moreno-Moreno, and F. Guerra-Vásquez. 2011. Extension of the geographical range of white-browed titi monkeys (Callicebus discolor) and evidence for sympatry with San Martin titi monkeys (Callicebus oenanthe). International Journal of Primatology 32: 924-930.

von Tschudi, J.J. 1844. Untersuchungen über die Fauna Peruana. (Theriologie: 1-262). St. Gallen: Scheitlin und Zollikofer.

Voss, R.S. 2011. Revisionary notes on Neotropical porcupines (Rodentia: Erethizontidae) 3. An annotated checklist of the species of Coendou Lacépède, 1799. American Museum Novitates 3720: 1-36.

Voss, R.S. 2015. Superfamily Erethizontoidea Bonaparte, 1845. In J.L. Patton, U.F.J. Pardiñas, and G. D’Elía (editors), Mammals of South America, vol. 2: Rodents: 786-805. Chicago: University of Chicago Press.

Voss, R.S., and L.H. Emmons. 1996. Mammalian diversity in Neotropical lowland rainforests: a preliminary assessment. Bulletin of the American Museum of Natural History 230: 1-115.

Voss, R.S., and S.A. Jansa. 2009. Phylogenetic relationships and classification of didelphid marsupials, an extant radiation of New World metatherian mammals. Bulletin of the American Museum of Natural History 322: 1-177.

Voss, R.S., D.P. Lunde, and N.B. Simmons. 2001. The mammals of Paracou, French Guiana: a neotropical lowland rainforest fauna Part 2. Nonvolant species. Bulletin of the American Museum of Natural History 263: 1-236.

Voss, R.S., C. Hubbard, and S.A. Jansa. 2013. Phylogenetic relationships of New World porcupines (Rodentia, Erethizontidae): implications for taxonomy, morphological evolution, and biogeography. American Museum Novitates 3769: 1-36.

Wagner, J.A. 1842. Diagnosen neuer Arten brasilischer Säugthiere. Archiv für Naturgeschichte 8 (1): 356362.

Wagner, J.A. 1847. Beiträge zur Kenntniss der Säugthiere Amerika's. Abhandlungen der Mathematisch-Physikalischen Klasse der Königlich Bayerischen. Akademie der Wissenschaften 5: 121-208.

Wagner, J.A. 1855. Die Säugthiere in Abbildungen nach der Natur mit Beschreibungen von Dr. Johann Christian Daniel von Schreber. Supplementband. Fünfte Abtheilung: Die Affen, Zahnlücker, Beutelthiere, Hufthiere, Insektenfresser und Handflügler. Leipzig: T.O. Weigel.
Webster, W.D. 1993. Systematics and evolution of bats of the genus Glossophaga. Special Publications, Texas Tech University Museum 36: 1-184.

Webster, W.D., and J.K. Jones, Jr. 1980. Noteworthy records of bats from Bolivia. Occasional Papers of the Museum of Texas Tech University 68: 1-6.

Weksler, M., and C.R. Bonvicino. 2015a. Genus Neacomys Thomas, 1900. In J.L. Patton, U.F.J. Pardiñas, and G. D'Elía (editors), Mammals of South America, vol. 2: Rodents: 361-369. Chicago: University of Chicago Press.

Weksler, M., and C.R. Bonvicino. 2015b. Genus Oligoryzomys Bangs, 1900. In J.L. Patton, U.F.J. Pardiñas, and G. D'Elía (editors), Mammals of South America, vol. 2: Rodents: 417-437. Chicago: University of Chicago Press.

Weksler, M., and A.R. Percequillo. 2011. Key to the genera of the Tribe Oryzomyini (Rodentia: Cricetidae: Sigmodontinae). Mastozoologia Neotropical 18: 281-292.

Weksler, M., A.R. Percequillo, and R.S. Voss. 2006. Ten new genera of oryzomyine rodents (Cricetidae: Sigmodontinae). American Museum Novitates 3537: 1-29.

Wenzel, R.L. 1976. The streblid batflies of Venezuela (Diptera: Streblidae). Brigham Young University Science Bulletin-Biological Series 20 (4): 1-177.

Williams, S.L., and H.H. Genoways. 1980. Results of the ALCOA Foundation-Suriname expeditions. II. Additional records of bats (Mammalia: Chiroptera) from Suriname. Annals of Carnegie Museum 49: 213-236.

Williams, S.L., and H.H. Genoways. 2008 (“2007”). Subfamily Phyllostominae Gray, 1825. In A.L. Gardner (editor), Mammals of South America, vol. 1: Marsupials, xenarthrans, shrews, and bats: 255-300. Chicago: University of Chicago Press.

Wilson, D.E. 2008a ("2007"). Family Thyropteridae Miller 1907. In A.L. Gardner (editor), Mammals of South America, vol. 1: Marsupials, xenarthrans, shrews, and bats: 392-396. Chicago: University of Chicago Press.

Wilson, D.E. 2008b (“2007”). Genus Myotis Kaup, 1829. In A.L. Gardner (editor), Mammals of South America, vol. 1: Marsupials, xenarthrans, shrews, and bats: 468-481. Chicago: University of Chicago Press.

Wilson, D.E., and J.S. Findley. 1977. Thyroptera tricolor. Mammalian Species 71: 1-3.

Woodman, N. 2007. A new species of nectar-feeding bat, genus Lonchophylla, from western Colombia and western Ecuador (Mammalia: Chiroptera: Phyllostomidae). Proceedings of the Biological Society of Washington 120: 340-358. 
Woodman, N., and R.M. Timm. 2006. Characters and phylogenetic relationships of nectar-feeding bats, with descriptions of new Lonchophylla from western South America (Mammalia: Chiroptera: Phyllostomidae: Lonchophyllini). Proceedings of the Biological Society of Washington 119: 437-476.

Zortéa, M., R. Gregorin, and A.D. Ditchfield. 1998. Lichonycteris obscura from Espírito Santo state, southeastern Brazil. Chiroptera Neotropical 4: 95-96.

\section{APPENDIX}

\section{Selected Collecting Localities for STURNIRA GIANNAE}

Below we list all specimens of Sturnira giannae that we personally examined along with their respective localities. Names of the largest administrative unit (department, state, etc.) within each country are italicized, and geographic coordinates are provided.

\section{BOLIVIA}

Beni, Cercado, ca. 4 kilometers from Tijamuchi River mouth (14.166667 S, 64.966667 W; AMNH 210732).

Beni, General José Ballivian, ca. 5 kilometers southwest of Buena Hora (11.566667 S, 65.216667 W; AMNH 210723).

Beni, General José Ballivian, ca. 8 kilometers north of Santa Cruz (10.933333 S, 65.333333 W; AMNH 210730).

Beni, Iténez, ca. 1 kilometer below Paragua River mouth, Remansos (13.566667 S, 61.900000 W; AMNH 209424).

Beni, Mamoré, Mamoré River, opposite Cascajal (12.216667 S, 65.216667 W; AMNH 210724).

Beni, Vaca Diez, ca. 5 kilometers south of Guayaramerin, Mamoré River (10.866667 S, 65.416667 W; AMNH 209418).

Beni, Yacuma, ca. 2 kilometers from Yacuma River mouth (13.633333 S, 65.416667 W; AMNH 210733).

Pando, Abuna, Bella Vista (11.383333 S, 67.200000 W; AMNH 262473)
Pando, Manuripi, Madre de Díos River, Gargantua Island (12.383333 S, $68.583333 \mathrm{~W}$; AMNH 262483).

Pando, Nicolas Suarez, Nareuda River (11.302222 S, 68.916667 W; AMNH 248862, 248873).

BRAZIL

Amazonas, Borba, Madeira River (4.400000 S, 59.583333 W; AMNH 92200, 92227).

Amazonas, Manaus, Igarapé Cacao Pereira, Negro River (3.150000 S, 60.116667 W; AMNH 91467-91469).

Pará, Faro, Amazon River, north bank, Serra do Espelho (2.183333 S, 56.733333 W; AMNH 93896, 93897).

ECUADOR

Orellana, Parque Nacional Yasuní, Estación Científica Onkone Gare, 38 km S Pompeya Sur (0.910000 S, 76.616000 W; ROM 105875).

\section{FRENCH GUIANA}

Cayenne, Sinnamary, Paracou $(5.383300 \mathrm{~N}$, 52.916700 W; AMNH 266207, 266210, 266236, 268545).

GUYANA

Upper Demerara-Berbice, Mabura Hill (5.283333 N, 58.633333 W; ROM 103552).

\section{PERU}

Amazonas, Luya, Río Utcubamba, $11 \mathrm{~km}$ by road NW Pedro Ruíz (5.933333 S, 78.100000 W; FMNH 128825).

Ayacucho, La Mar, Hacienda Luisiana on Apurimac River (12.666667 S, 73.733333 W; AMNH 208063, 208064).

Cajamarca, Santa Cruz, Río Zaña, 2 km N Monte Seco (6.850000 S, 79.066700 W; FMNH 128845).

Cuzco, La Convención, Cordillera Vilcabamba, Mapitunari River (12.650000 S, 73.700000 W; AMNH 233541).

Cuzco, Paucartambo, San Pedro (13.054667 S, 71.546233 W; FMNH 172153). 
Huánuco, Leoncio Prado, 9 km S, 2 km E Tingo María (9.366700 S, 75.966700 W; TTU 46270).

Junín, Chanchamayo, 2 miles northeast of San Ramon (11.250000 S, 75.316667 W; AMNH 230526, 230529, 230545, 230546).

Loreto, Alto Amazonas, Gálvez River, Nuevo San Juan (5.250800 S, 73.163300 W; MUSM 13260).

Loreto, Maynas, Curaray River (2.363333 S, 74.090556 W; AMNH 71691-71695).

Loreto, Maynas, Estación Biológica Isla Muyuy (3.966667 S, 73.066667 W; MUSM 21266).

Loreto, Reserva Nacional Allpahuayo-Mishana, Estación Biológica "José Álvarez Alonso" (3.966667 S, 73.416667 W; ROM F63353).

Loreto, Maynas, Río Maniti, Santa Cecilia (3.555500 S, 72.883300 W; FMNH 87058).

Loreto, Requena, Jenaro Herrera, Centro de Investigaciones Jenaro Herrera (4.898600 S, 73.650300 W; MUSM 5922, 5924, 5925).

Pasco, Oxapampa, Nevati Mission (10.350000 S, 74.850000 W; AMNH 230558).

Pasco, Oxapampa, San Juan (10.500000 S, 74.883333 W; AMNH 230567, 230568).

Pasco, Oxapampa, San Pablo (10.450000 S, 74.866667 W; AMNH 230582).

San Martín, Moyobamba, Área de Conservación Municipal Mishquiyacu-Rumiyacu y Almendra, Orquidiario Waqanki (6.075100 S, $76.976000 \mathrm{~W}$; FMNH 203408, 203410, 203412, 203416, 203582, 203584, 203586, 203590; MUSM 39223-39227).

San Martín, Moyobamba, Área de Conservación Municipal Asociación Hídrica Aguajal Renacal del Alto Mayo, Tingana (5.910700 S, 77.112000 W; FMNH 203420; MUSM 39229).

San Martín, Rioja, Pardo Miguel, Naranjos, Caserio El Diamante (5.753400 S, $77.526100 \mathrm{~W}$; FMNH 203414, 203588; MUSM 39228).

Ucayali, Atalaya, Tahuania, Shahuaya (9.841100 S, 74.105368 W; AMNH 230535-230537).
SURINAME

Sipaliwini, Blanche Marie Vallen (4.756110 N, 56.879440 W; ROM 117574, 117642).

TRINIDAD AND TOBAGO

Tobago, Saint Patrick, Grange (11.183300 N, 60.783300 W; TTU 44085).

Trinidad, Saint Andrew, Balandra (10.721552 N, 60.991014 W; AMNH 204710).

Trinidad, Saint Andrew, Sangre Grande, Rio Grande Forest (10.583333 N, 61.116667 W; AMNH 204717).

Trinidad, Saint George, Arima, 5 mi N (10.706100 N, 61.283300 W; TTU 44090).

Trinidad, Saint George, Simla Research Center, 4 mi N Arima $(10.691500 \mathrm{~N}, 61.283300 \mathrm{~W}$; TTU 44092).

Trinidad, Saint George, Churchill Roosevelt Highway, 15.75 mile mark $(10.618246 \mathrm{~N}$, 61.255255 W; AMNH 179953).

Trinidad, Saint George, La Fillette (10.800000 N, 61.350000 W; AMNH 204712).

Trinidad, Saint George, Las Cuevas (10.766667 N, 61.383333 W; AMNH 204723).

Trinidad, Saint George, Maracas (10.683333 N, 61.400000 W; AMNH 204726).

Trinidad, Saint George, Maracas, Waterfalls Road (10.721198 N, 61.409138 W; AMNH 178652).

\section{VENEZUELA}

Bolivar, $3 \mathrm{~km}$ E of Puerto Caballo del Caura (7.166700 N, 64.983300 W; ROM 107936). Bolívar, $8 \mathrm{~km} \mathrm{~S} 5 \mathrm{~km}$ E El Manteco (7.349900 $\mathrm{N}, 62.541100 \mathrm{~W}$; CM 78567). 



\title{
Scientific Publications of the American Museum of Natural History
}

AMERICAN MUSEUM NOVITATES

BULletin of the AmERICAN Museum of Natural History

anthropological papers of the american museum of Natural History

\author{
Publications Committee \\ ROBERT S. VOSS, CHAIR \\ BOARD OF EDITORS \\ jin Meng, Paleontology \\ LORENZO Prendini, INVERTEBrate ZOOLOGY \\ Robert S. Voss, Vertebrate ZoOlogy \\ Peter M. Whiteley, Anthropology \\ MANAGING EDITOR \\ MARY KNIGHT
}

Submission procedures can be found at http://research.amnh.org/scipubs

All issues of Novitates and Bulletin are available on the web (http://digitallibrary.amnh. org/dspace). Order printed copies on the web from:

http://shop.amnh.org/a701/shop-by-category/books/scientific-publications.html

or via standard mail from:

American Museum of Natural History-Scientific Publications

Central Park West at 79th Street

New York, NY 10024

(0) This paper meets the requirements of ANSI/NISO Z39.48-1992 (permanence of paper).

ON THE COVER: A MALE SPECIMEN OF STURNIRA GIANNAE ROM F63353 photographed at the Reserva Nacional Allpahuayo-Mishana, Loreto, Peru, by MARco TSChapka. 